\title{
THE IOWAN DRIFT, A REVIEW OF THE EVIDENCES OF THE IOWAN STAGE OF GLACIATION
}

BY

WM. C. ALDEN and MORRIS M. LEIGHTON

Prepared in Cooperation with the Unitbd States Geological Survey 



\section{CONTENTS}

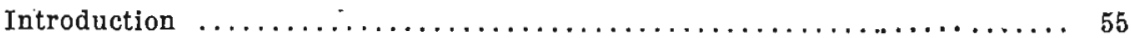

Character of the investigation and general results.............. 55

Chapter I. The Iowan drift.............................. 60

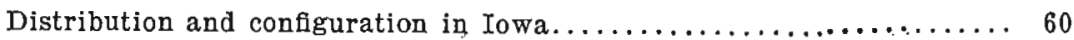

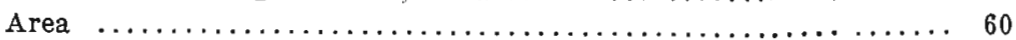

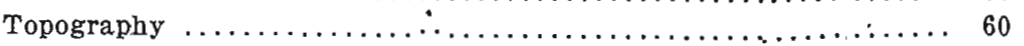

Chapter II. The uppermost till of the Iowan area................ 77

The lithology of the Iowan drift and its comparison with other drifts.. 79

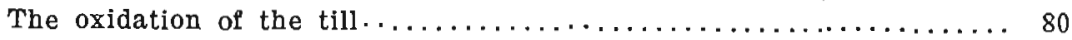

The effects of leaching $\ldots \ldots \ldots \ldots \ldots \ldots \ldots \ldots \ldots \ldots \ldots, 81$

The overlying loesslike clay $\ldots \ldots \ldots \ldots \ldots \ldots \ldots \ldots \ldots \ldots \ldots \ldots, 83$

Comparison with the Kansan till.......................... 83

The oxidation of the Kansan drift....................... 83

The leaching of the Kansan drift...................... 85

Comparison with the Wisconsin till...................... 88

Chapter III. The super-Kansan" "gumbo"........................ 89

In the Kansan drift area............................... 89

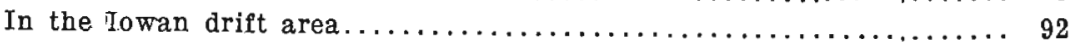

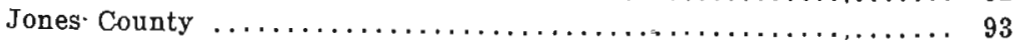

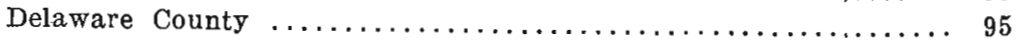

Buchanan County ........................................ 96

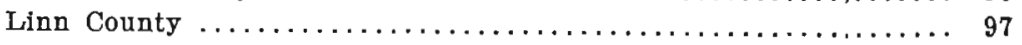

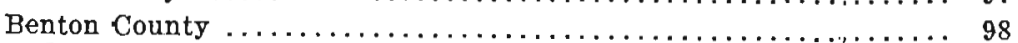

Bláck Hawk County................................ 99

Fayette County ..................................... 100

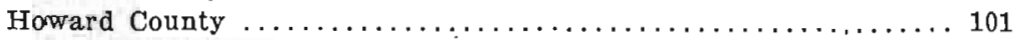

Mitchell County .................................... 102

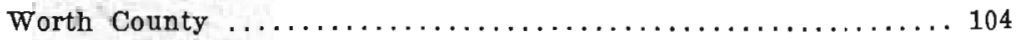

Cerro Gordo County................................. 104

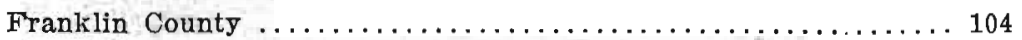

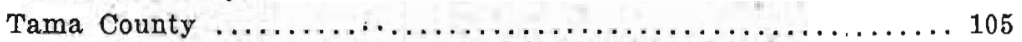

Chapter IV. Other evidences of post-Kansan glaciation.............. 110

General character ..................................... 110

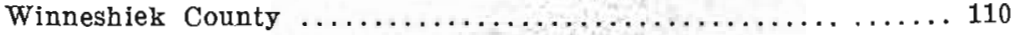

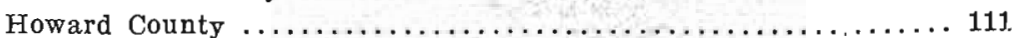

Chickasaw County ................................. 111

Buchanan County .................................. 112

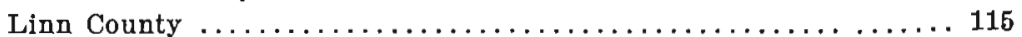

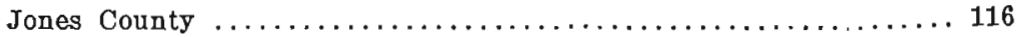

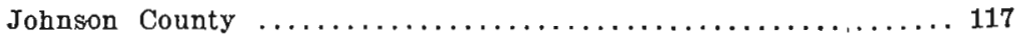

Chapter v. Bowlders................................... 121 
Character and size.................................. 121

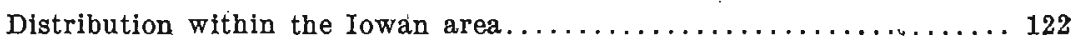

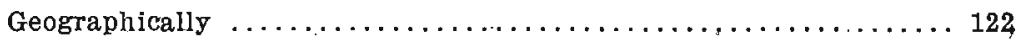

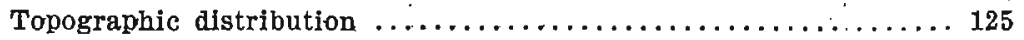

Character of embedding till ........................ 126

Bowlders in the Kansan area......................... 126

Big bowlders as evidence of Iowan glaciation. . . . . . . . . . . . . 127

Chapter VI. Iowan outwash and other gravels.................. 130

Valley train terraces............................ 130

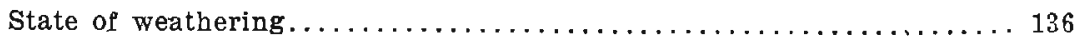

Absence of glacio-fluvial gravel in certain valleys of the Kansan area. 137

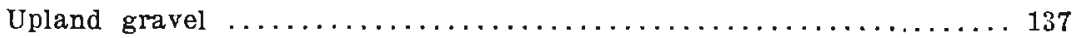

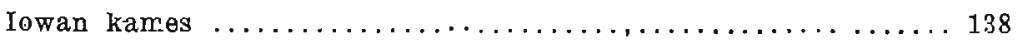

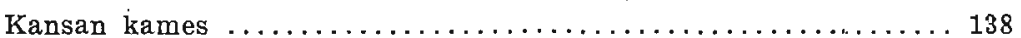

Comparison with gravels of Wiseonsin age . . . . . . . . . . 139

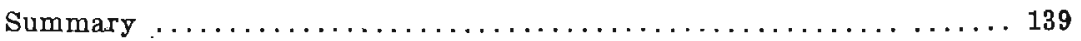

Chapter VIJ. The loess and its significance................. 140

General characters . . . . . . . . . . . . . . . . 140

The fossil content and its significance................... 141

Modification of the loess by weathering ................... 142

Distribution of the loess................................. 144

Conclusion as to sources of the loess..................... 153

Stratigraphic relations of the loess............................ 154

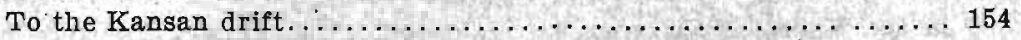

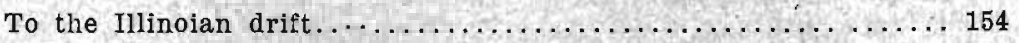

Relations to the Iowan drift....................... 156

Relations to the $W$ isconsin drift...................... 158

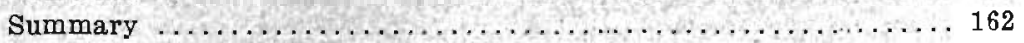

Conclusions from relations of the loess.................. 164

Chapter VIrI. The age of the lowan drift.................... 164

Chapter IX. Border phenomena and limits of the Iowan drift......... 171,

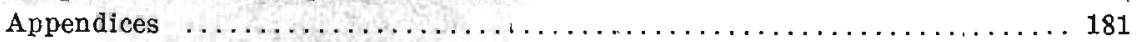

A. Tables of estimates of lithologic composition of the drift........ 181

1. Estimates of pebbles frcm unleached Wisconsin drift........ 182

2. Estimates of pebbles from unleached part of uppermost till, or Iowan, of the Iowaz area................. 183

3. Estimates of pebbles from leached part of uppermost till, or Iowan, of the lowan area..................... 184

4. Estimates of pebbles from Buchanan(?) gravel in Iowan area. . 135

5. Estimates of pebbles from unleached Kansan(?) till of Iowan

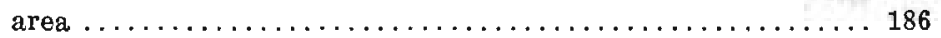

6. Estimates of pebbles from the leached and oxidized upper part of the Kansan till outside of Iowan area............... 187

7. Estimates of pebbles from the unleached Kansan till outside of Iowan area .............................. 188

8. Estimates of pebbles from Aftonian gravels............. 189

9. Estimates of pebbles from sub-Aftonian, or Nebraskan, till... 189 
B. Notes on exposures of super-Kansan "gumbo," in the Kansan drift

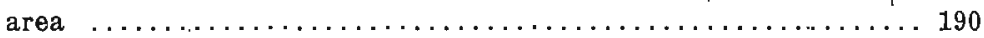

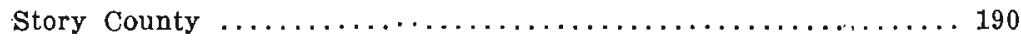

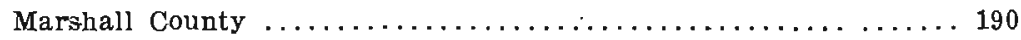

Foweshiek County ............................. 192

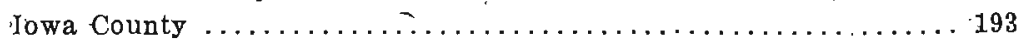

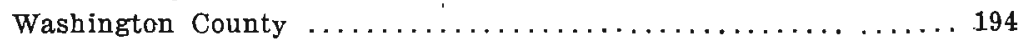

Johnson County ................................ 195

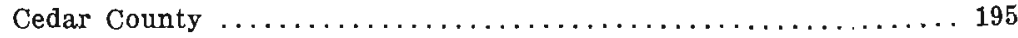

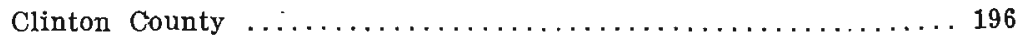

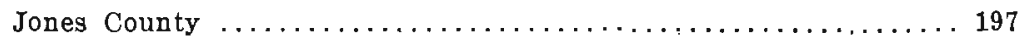

Scott County ................................ 198

Rock Island County, Illinois. . . . . . . . . . . . . . . 198

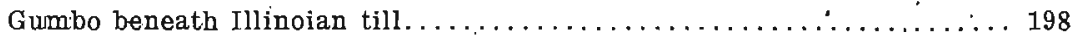

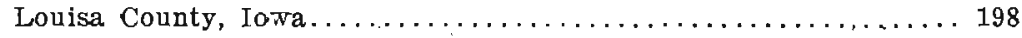

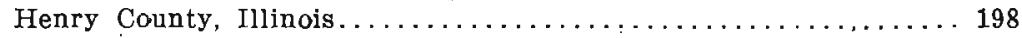

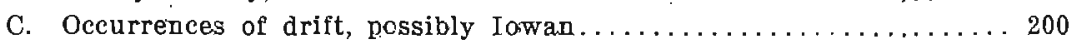

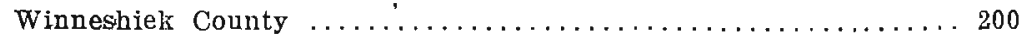

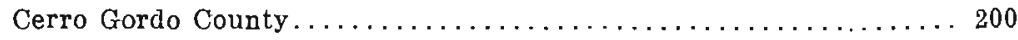

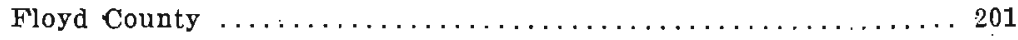

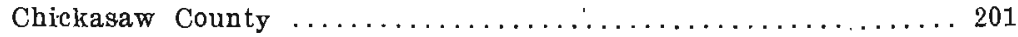

Bremer County ............................... 201

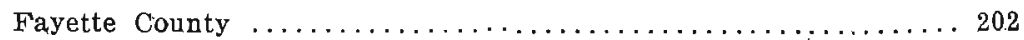

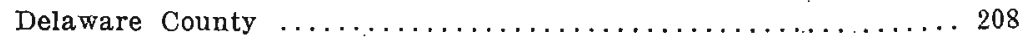

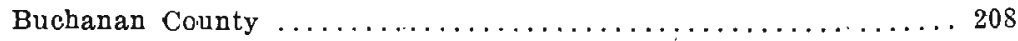

Black Hawk County ........................... 210

Benton County .............................. 210

Linn County ................................. 211

Jones County ............................... 212 
. 


\section{THE IOWAN DRIFT}

\section{A REVIEW OF THE EVIDENCES OF THE IOWAN STAGE OF GLACIATION}

\section{Introduction}

\section{CHARACTER OF THE INVESTIGATION AND GENERAL RESULTS}

F'or many years northeastern Iowa has been a region of great interest to students of Pleistocene geology and many papers have been published treating of its various features. Differentiation of the deposits as the product of several distinct ice invasions may be said to have begun with the tracing of the limits of the drift of the Des Moines lobe of the last ice sheet as Nistinguished from older drift in the area outside. Later the United States Geological Survey published W J McGee's paper on the Pleistocene of northeastern Iowa, ${ }^{1}$ in which he showed that there were two drift sheets in this part of the state which were older than the drift of the Des Moines lobe. Still later the Iowa Geological Survey, with the late Dr. Samuel Calvin at its head, reached the conclusion that instead of two drift sheets there were really three in northeastern Iowa, each the product of a distinct ice advance prior to the incursion of the Des Moines lobe. The progress of the investigations necessitated certain changes in the classification and the shifting of names to designate the deposits. It is not necessary to consider in this place these changes in the nomenclature nor the merits of such adjustments as were made. The elaboration of the remarkable Pleistocene classification that resulted from these and correlated studies called for close scrutiny of the evidence and almost inevitably differences of opinion arose concerning some of its features. Skepticism centered principally on the Iowan drift, said to be the product of the fourth great glacier which had invaded the area of the state or the third which spread over

\footnotetext{
${ }^{2} \mathrm{McGee}, \mathrm{W}$ J, The Pleistocene of northeastern Iowa: U. S. Geol. Survey Eleventh Ann, Rept., pt. 1, pp. 189-577, 1891.
} 
northeastern Iowa. This skepticism arose very largely because of difference of opinion as to the interpretation to be given certain of the phenomena observed. This was expressed particularly in several papers published by Frank Leverett of the United States Geological Survey. In defense of the Iowan drift a number of papers were published by Doctor Calvin. The discussion had to do principally with two questions: (1) Is there really in northeastern Iowa a drift sheet of pre-Wisconsin age distinct from, and younger than, the Kansan drift? and (2) If so, is it to be correlated with the Illinoian drift sheet (of Leverett), or was it the product of a distinctly later ice invasion? The matter was still in question at the time of Doctor Calvin's death in 1911. There being a desire for a review of the evidence bearing on the Iowan problem, Doctor Calvin's successor, the present State Geologist, Dr. George F. Kay, finally requested the United States Geological Survey to cooperate with the Iowa Survey in an investigation of the matter. An agreement was reached and the senior author of this leport was assigned to this work by the Federal Survey with Morris M. Leighton of the Iowa Survey as assistant.

The summer seasons of 1914 and 1915 were spent on the field investigations besides careful study of the published and unpublished material in the office. It is a pleasure to report that the conclusion has been reached that there is what seems to the writers to be good evidence of the presence of a post-Kansan drift sheet in northeastern Iowa and that this drift appears to be older than the Wisconsin and younger than the Illinoian drift. The writers are, therefore, in the main in agreement with the late State Geologist, Dr. Samuel Calvin, in regard to the Iowan drift. There is, therefore, warrant for continued use of Iowan drift and Iowan stage of glaciation as major subdivisions of the Pleistocene classification. This classification is as follows:

Pletstockine Epoor.

9. Wisconsin stage of glaciation (of Chamberlin)

8. Peorian stage of deglaciation (of Leverett)

7. Iowan stage of glaciation (of Iowa geologists)

6. Sangamon stage of deglaciation (of Leverett) 
5. Mlinoian stage of glaciation (of Leverett)

4. Yarmouth stage of deglaciation (of Leverett)

3. Kansan stage of glaciation (of Iowa geologists)

2. Aftonian stage of deglaciation (of Chamberlin)

1. Nebraskan stage of glaciation (of Iowa geologists) (pre-

Kansan of Chamberlin) (Jerseyan of eastern United States)

These subdivisions of Pleistocene time are represented in Iowa by the following:

Pumistocene Deposits.

9. Wisconsin drift (of the Des Moines lobe)

8. (b) Peorian soil and weathered zone (of Leverett) at top of loess and beneath Wisconsin drift

(a) Main deposit of loess'

7. Iowan drift (of Iowa geologists)

6. Sangamon soil, vegetal deposits, and weathered zone (of Leverett) (including super-Illinoian "gumbo," or "gumbotil"'of Kay) at top of Illinoian drift and beneath loess

5. Illinoian drift (of Leverett)

4. Yarmouth soil, vegetal deposits, and weathered zone (of Leverett) (including super-Kansan "gumbo," or "gumbotil" of Kay ) at top of the Kansan drift; also Buchanan gravel (of Iowa geologists) beneath Iowan drift and loess

3. Kansan drift (of Iowa geologists)

2. Aftonian gravels, vegetal deposits, soil and weathered zone (of Chamberlin) (including super-Nebraskan "gumbo" or "gumbotil" of Kay) at top of Nebraskan drift

1. Nebraskan drift (of Iowa geologists) (pre-Kansan or subAftonian of Chamberlin)

In the course of the field work about 175 traverses were made in and adjacent to the Iowan drift area and a large number of exposures were carefully examined. Fortunately, many new cuts were available as the result of recent grading on the wagon roads and electric and steam railways. In addition about 250

2Local deposits of loess and of laminated silts occur on the Wisconsin and older drift sheets.

${ }^{\mathrm{T}}$ Kay, Geo. F.. Gumbotil, a new term in Pleistocene. geology: Sclence, ncw ser., Vol. XLIV, pp. $637-638,1916$. 
borings were made with a 2-inch auger 8 feet in length. The auger was used principally where exposures were not available, particularly on the typical Iowan plains and other uplands Samples obtained thereby were carefully examined for determination of the character, the depth of leaching and degree of oxidation of the superficial parts of the drift. Not much attention was given to the collection of well data, reliance being placed on the statements in the reports of the Iowa Survey for the thickness of the drift.

Many examinations for purposes of comparison were made outside the Iowan drift area in. the Kansan and Illinoian drift areas in Iowa and by Mr. Alden on the Illinoian drift in Illinois. Besides these, a number of reconnaissance trips were made by $\mathrm{Mr}$. Alden in the area outside the Wisconsin terminal moraine in southeastern Minnesota. Some of these were in company with one or two of the following gentlemen, Frank Leverett, F. W. Sardeson, and Samuel Weidman. The writers are especially indebted to T. C. Chamberlin, R. D. Salisbury, George F. Kay and Frank Leverett. Conferences were had also with Wm. H. Norton, R. T. Chamberlin, J. E. Carman, A. C. Trowbridge, A. O. Thomas and J. A. Williams.

In connection with this study the writers were fortunate in having access to the field notes of the late Doctor Calvin, to an unpublished manuscript by $\mathrm{Mr}$. Leverett, to some notes by T. C. Chamberlin on field conferences in Wisconsin, Minnesota, and Iowa, and to field notes of R. T. Chamberlin on his studies in 1906 and 1907 of the drift in southern and eastern Iowa, southeastern Minnesota and northwestern Wisconsin, for the United States Geological Survey. In the course of these latter studies R. T. Chamberlin made many estimates of the lithologic composition of the several drift sheets by the counting and sorting of pebbles. Through his kindness the present writers are permitted to include in this report the results of these estimates together with the results of similar estimates made by themselves. They are compiled in the tables presented in Appendix A.

The writers are indebted to R. D. Salisbury for examination and criticism of a preliminary draft of the manuscript, 
and Frank Leverett and F. W. Sardeson also véry kindly examined and criticised the manuscript of this report. They are, however, in no way responsible for the interpretations presented. To all these gentlemen the writers wish to express their appreciation.

As stated above, the investigation has yielded what seems to the writers to be good evidence of a post-Illinoian and preWisconsin glaciation of northeastern Iowa. There may, of course, be room for differences of opinion as to some of the interpretations. Were the phenomena entirely clear and decisive the question would not so long have remained open. The evidence is not, however, like a chain whose maximum strength is that of the weakest link, but may rather be likened to a rope composed of strands none of which alone may be able to support the burden but whose combined pull in the same direction brings conviction.

Inasmuch as this paper is intended primarily as a review of the evidence rather than as an argument in favor of the Iowan stage of glaciation the effort has been made to bring together about all the available data bearing on the question. Some of the less important details have been put in the appendices. Some of these have little value as evidence and some may not appear to be pertinent. Quite a number of different persons have studied the Pleistocene geology of this region and numerous supposed occurrences of Iowan drift have been cited, so that it has seemed best to take cognizance of data published even though some of it may not now appear very important.

It has been thought not to be necessary to present in this paper a detailed discussion of the history and development of the classification of the Pleistocene deposits of Iowa. There are in the text numerous references to earlier publications of various writers, but no bibliography or, review of papers treating of the Iowan drift is presented. For reference to these papers readers should consult the annotated bibliography of Iowa geology and mining by Charles Keyes, volume XXII, Iowa Geological Survey (1912) or the several bibliographies of North American geology published by the United States Geological Survey. 


\section{CHAPTER 1}

\section{THE IOWAN DRIFT.}

\section{DISTRIBUTION AND CONFIGURATION IN IOWA.}

Area.-The evidence reviewed in this paper seems to the writers to indicate that a post-Kansan glaciation (pre-Wisconsin and post-Illinoian) extended over that part of northeastern Iowa lying between the east boundary of the Wisconsin drift on the west and the belt of thin drift bordering the Driftless Area on the east. The drift deposited at this stage is the Iowan drift. The Iowan ice sheet may also have covered part of southeastern Minnesota, but the writers have not themselves examined enough of that area to warrant its discussion in this paper. The Iowan drift in Iowa lies principally in the basins of Cedar and Wapsipinicon rivers. The eastern part is drained by the headwaters of Upper Iowa, Turkey, Volga, and Maquoketa rivers and some of the southern part of the area drains to Iowa river. This area, more than 9,000 square miles, is larger than Massachusetts and about equal to New Hampshire or Vermont, and somewhat less than Maryland.

Topography.-Comparisons of surficial configuration and $o_{i}$ the degree of modification of the drift by erosion have generally been among the criteria for discrimination of the relative ages of different drift sheets so that this review may well begin with a study of the topography. The sort of topography generally characteristic of this part of northeastern Iowa is somewhat peculiar and it is recognized that there may be considerable difference of opinion as to its interpretation. The influence of certain factors such as of slope, of material and of vegetal cover, and of earlier climatic conditions, are not readily evaluated and their discussion is not attempted in this connection. Such study of this and adjacent areas as the writers have made in the course of this investigation seems to them, however, to show topographic differences which, taken in connection with the other data here presented, are significant of differences in the age of the glacial drift. 

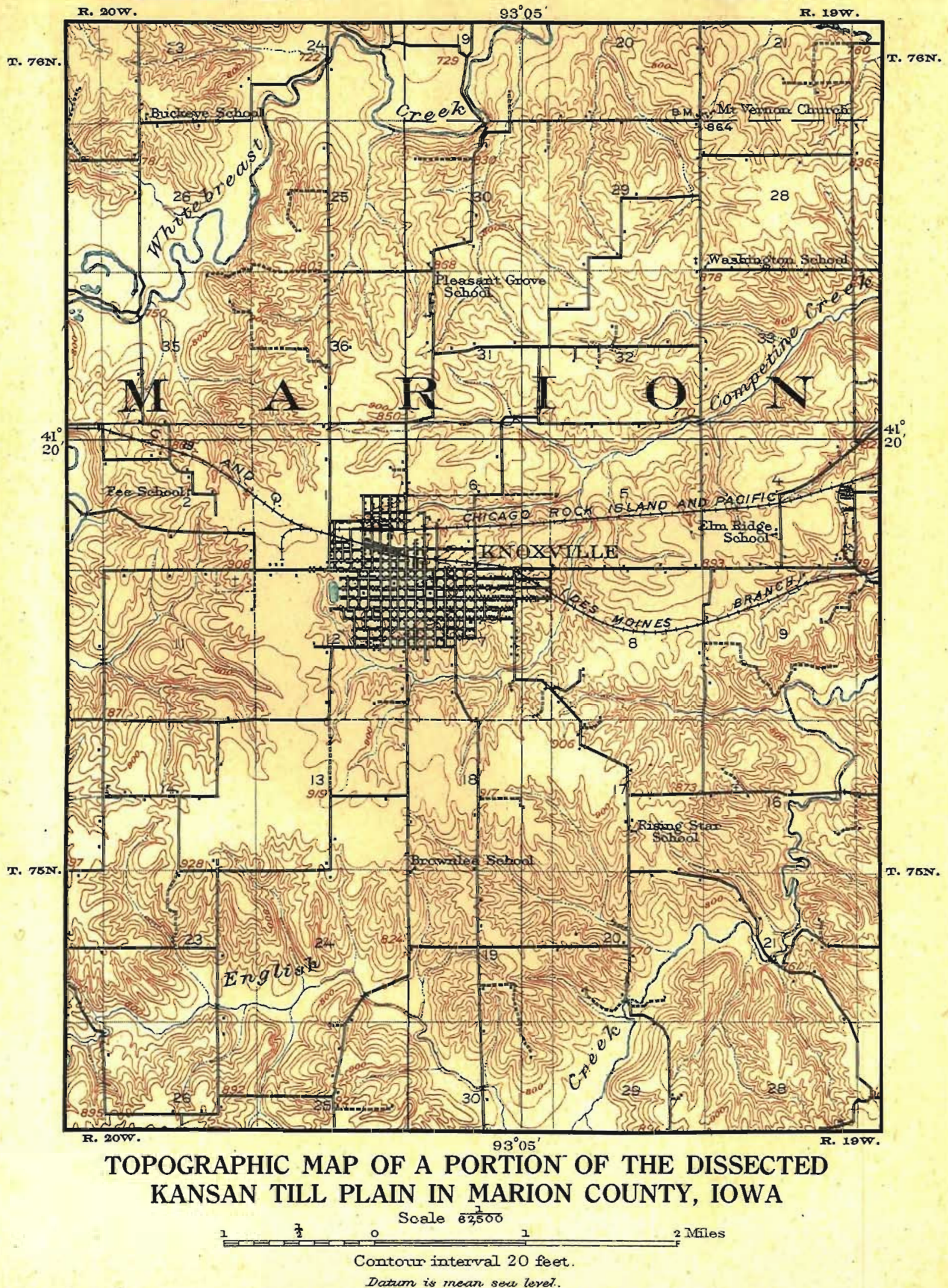


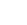
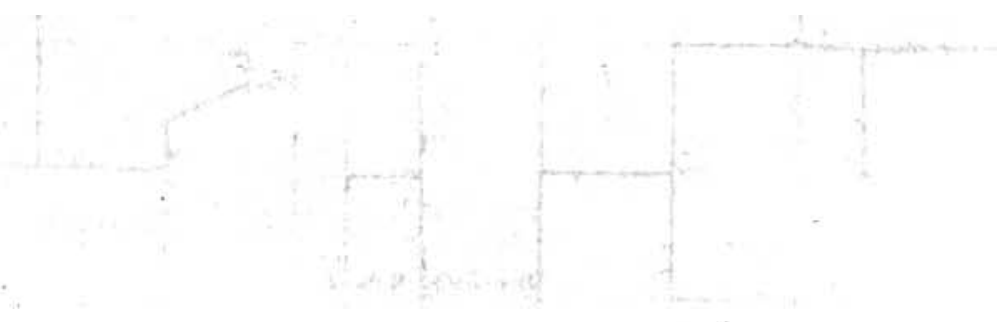
The topography of the Iowan area is, in general, what the writers would call a mantled, mature-erosion type. There is not, with some exceptions, the depositional type seen in the Wisconsin drift area where the surface configuration is largely, if not primarily, due to the irregular deposition of the drift, either of the undulating ground moraine type or the sag-andswell, or knob-and-kettle morainal type, with the nearly total obliteration of the configuration of the underlying surface. In the Iowan area, though it is not generally dissected by sharp-cut, eroded valleys, there are yet present nearly everywhere the main features of maturely branching stream-erosion systems. The valleys divide and sub-divide in dendritic fashion and their branches reach most parts of the area. Even the more nearly flat and less dissected parts show this drainage pattern.

There is a difference, however, between this topography and that of most of those parts of the Kansan drift area known to the writers. In the latter there is not only deep dissection but the ramifications of the branches are developed in minute detail down to ravines and gullies trenching the slopes at intervals of a few rods. Convex curves prevail on the slopes and more or less sharply cut, $V$-shaped, cross-profiles predominate except in . the broader, flat-bottomed valleys.

The topography of the Kansan drift, which has been developed by long erosion of a nearly flat drift plain, is well illustrated by the contours on Plate I, reproduced from a part of the Knoxville topographic sheet. This is one of the newly surveyed areas and the dissected topography is about as accurately reproduced as the scale of the map permits. There is, however, even more detailed dissection of slopes than can be shown on this scale. There is a relief of 100 to 200 feet in this area and only narrow remnants of the original plain remain as uplands; and, as seen in the field, it would be noted that even much of the upland tracts is scarred by the tips of the erosion lines.

This type of topography and degree of dissection is characteristic of nearly all parts of the Kansan drift area which have been seen by the writers. The same is illustrated by Plates III and IV. 
In the Iowan drift area, while the main features of the dendritic branching systems are present the minor details are more generally lacking. V-shaped cross- profiles are rarely seen. The side slopes are long and of low grade and pass at the bottom into concave curves. The minor valleys are thus broad open swales which fade out indefinitely into nearly flat, interstream, upland areas. Though these valleys are quite capacious in their lower parts, as the relief ranges from 30 to 150 feet, the slopes are smooth and uncut, or very little cut, by ravines and gullies. One looks in vain, in most places, for the smaller branches and twigs of the dendritic system. The present streams do not appear to have been the sole agents in giving the valleys their present contours. These streams meander in shallow trenches cut in broad bottoms of the swales. The waters from the valley slopes appear to run off in sheets, so to speak, rather than by gathering into converging gullies and ravines: One looks directly down open troughs, broad and relatively shallow, though often of considerable actual depth, and sees the slopes in large measure unsearred by erosion lines and not made irregular by projecting spurs.

This type of topography is fairly well illustrated in Plate II which is a reproduction of parts of the Marion and Anamosa topographic sheets on the same scale as Plate I. This shows a part of the typical lowan drift plain. It should be noted that this is from the older and less accurate of the topographic sheets. Parts of this older set of maps which cover maturely. dissected Kansan drift areas to the east of the Iowan drift area and to the south in Cedar, Johnson, and Iowa counties, do not represent the dissected topography there with anything like the accuracy of detail found on the newer maps. This is true ulso of those parts of the older maps covering Illinoian drift areas in Scott and Muscatine counties, so that comparisons should not be made of the contouring of the typical Iowan topography on these old maps with that of the Kansan or llinoian topography on the same set of maps. On the other hand, critical examination in the field shows that the typical lowan topography, such as that of the part of Linn county strown in Plate II is fairly well represented by the apparently 


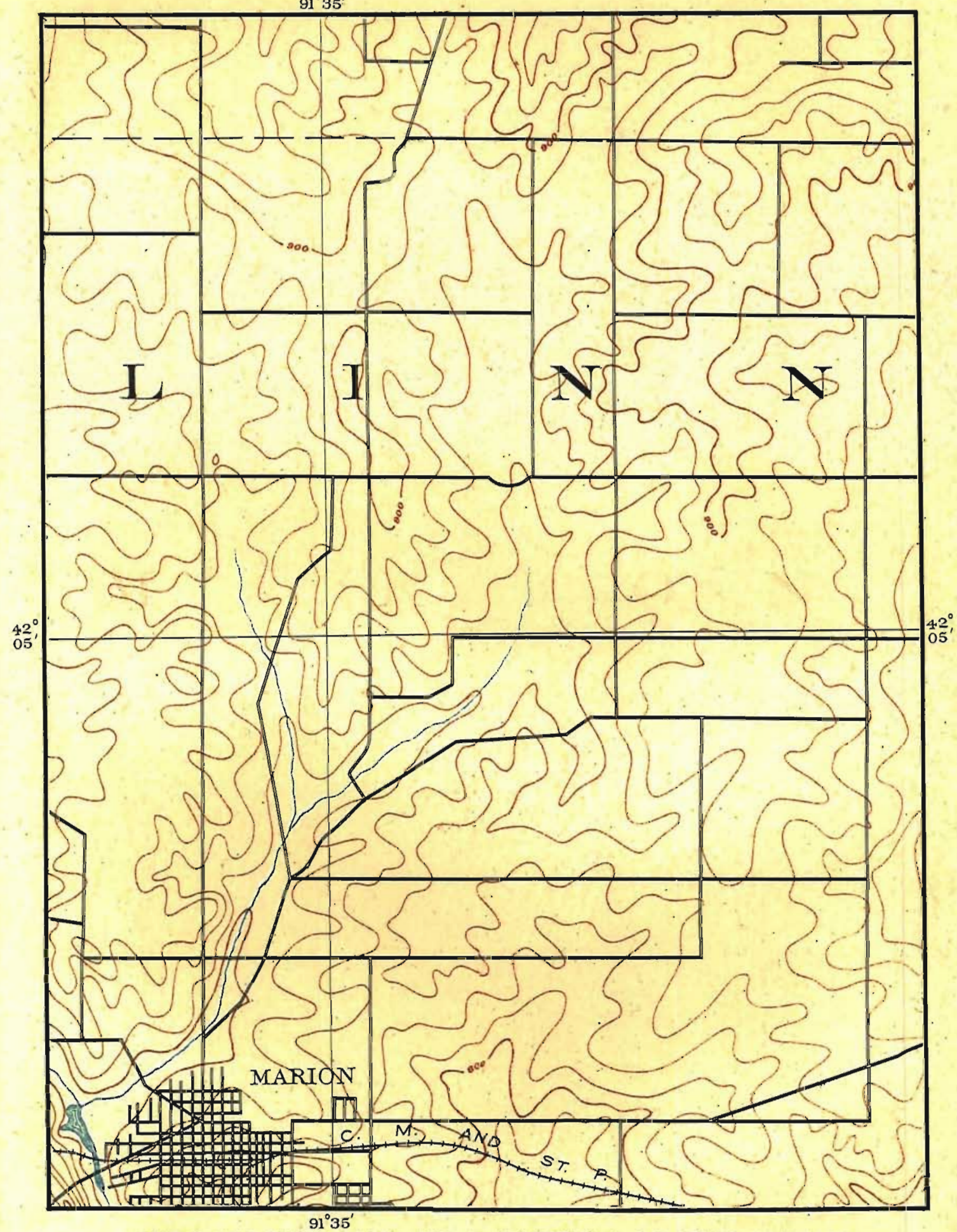

TOPOGRAPHIC MAP OF A PORTION OF THE IOWAN DRIFT PLAIN IN LINN COUNTY, IOWA 


\section{.}


Iowa Geological Survey.

PLaAte III.

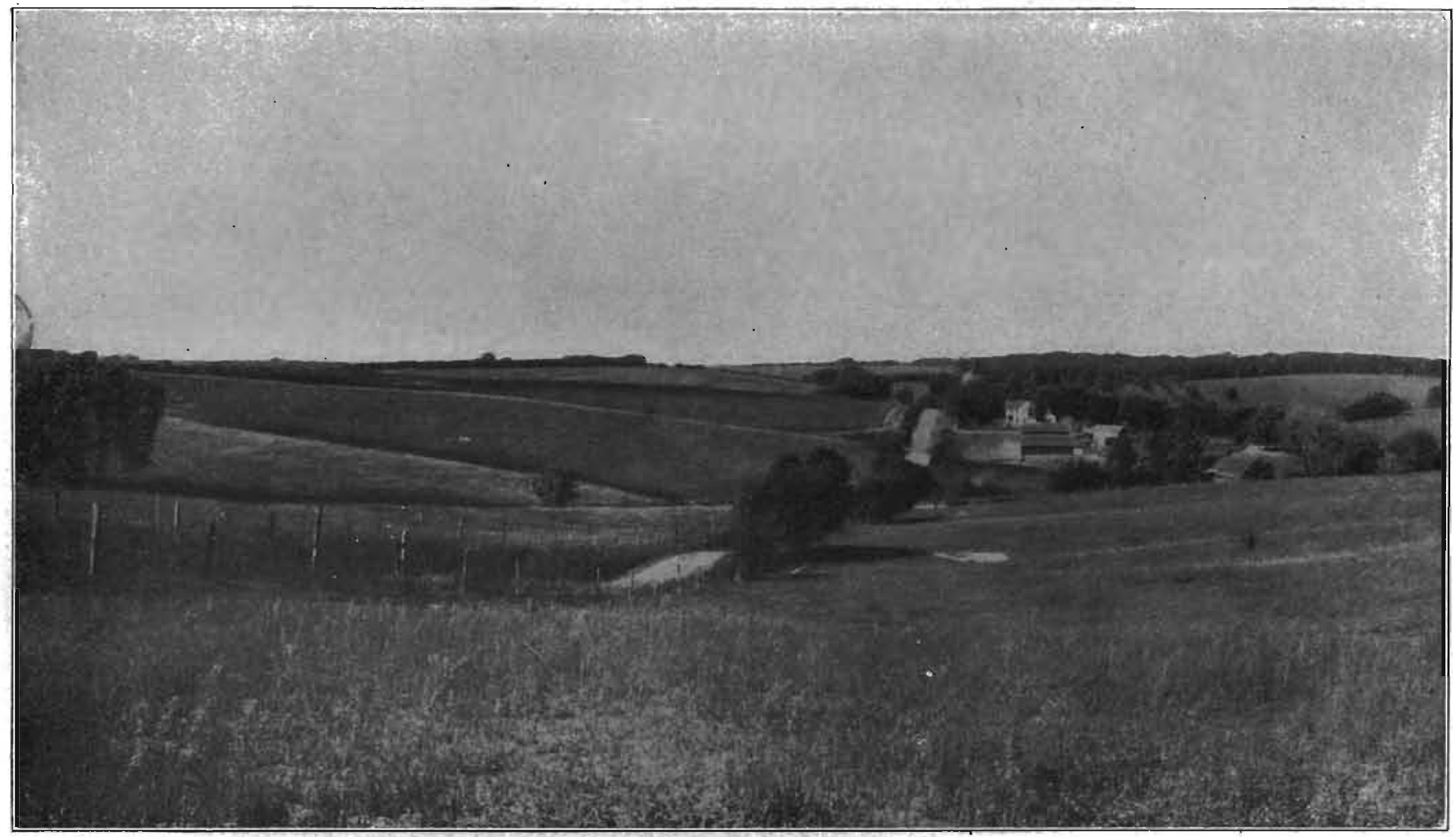

Vlew in northeastem Washington County, Jowa, showing mature erosion of the Kansan drift pla!n. Ziellef 100 to 150 teet. 


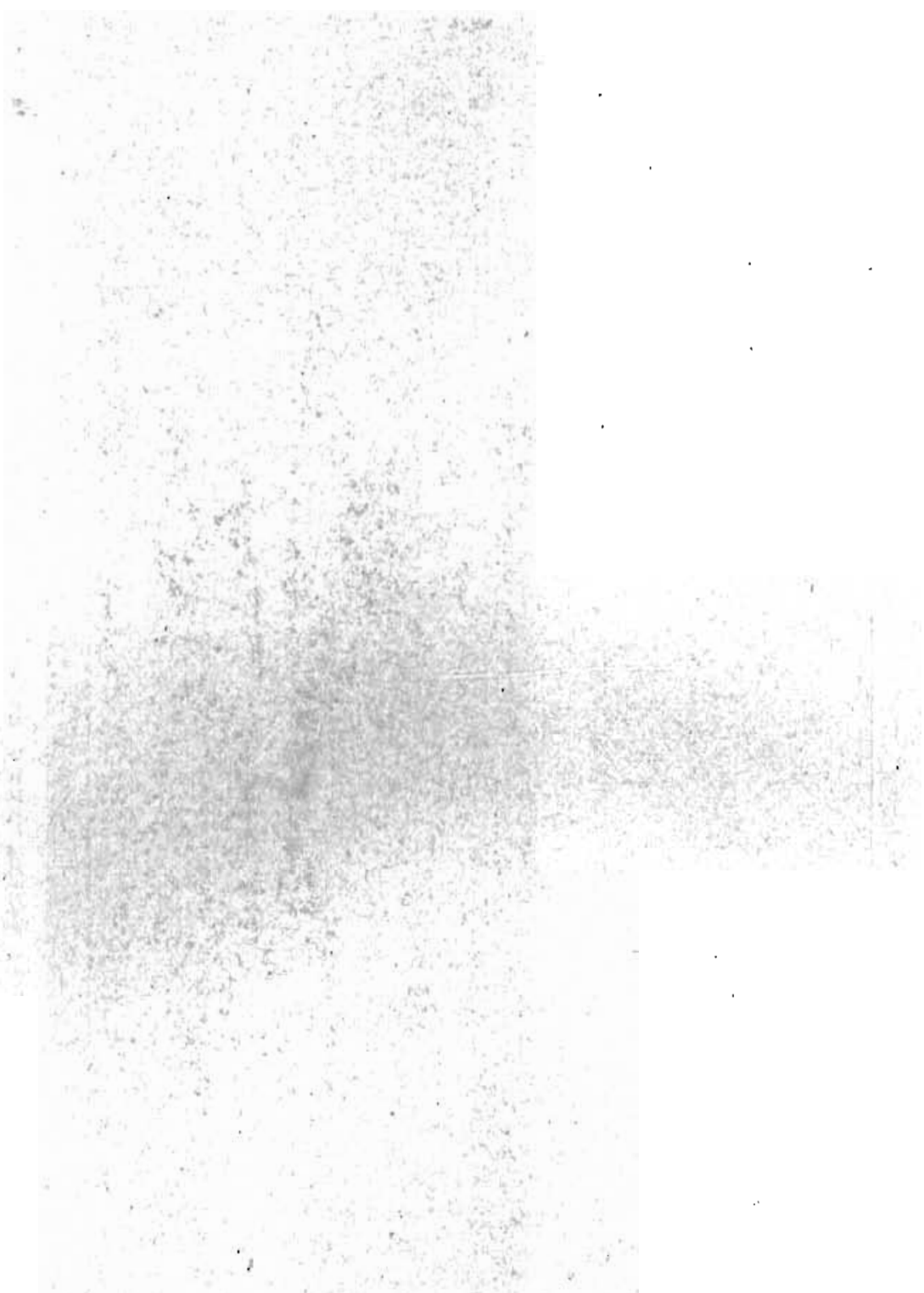




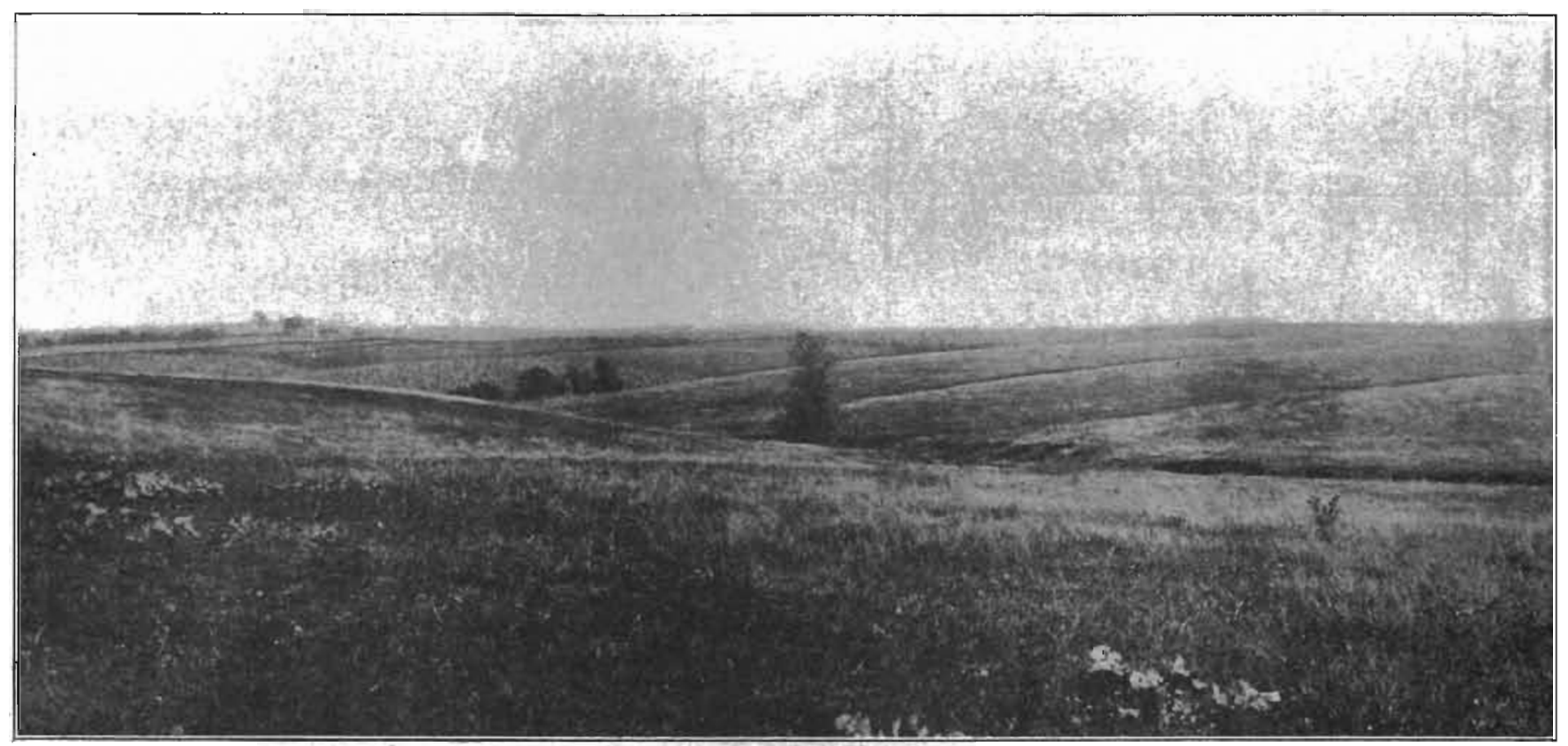

View in Union County, southeast of Afton, fowa, showing branching of erosion lines on the dissected Kansan drift plain. 


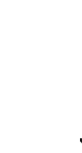


generalized contours used. The contour lines which mark the reëntrants of the long undissected slopes of the swales should be open, rounded curves, such as are shown, rather than the sharply angular $\mathrm{V}$-shaped reëntrants required to represent the dissected slopes of the Kansan and Illinoian drift areas.

Comparison of Plate II with Plate I shows the character of the Iowan drift plain as here represented to be distinctly different from the much dissected topography of the Kansan drift. The careful and critical observer who has seen thousands of square miles of this type of topography is impressed with the idea that it must be the result of some different geologic condition from that which produced so much of the Kansan topography. The reader should bear in mind that, while there are limited tracts in the midst of the Iowan area and especially in the border belts where there is considerably sharper relief and more dissection, the type here shown is characteristic of thousands of square miles of the Iowan drift area. It is the prevailing type of the Iowan drift topography. There are also some limited tracts with topography similar to the Iowan in the Kansan drift area, but so far as the experience of the writers goes it is distinctly the exception rather than the rule on that drift.

The impression gained by the writers from a careful study of this topography is that a dendritic-branching system had developed to maturity throughout the region by erosion, but that it was later masked in the Iowan drift area as though overridden by an ice sheet which left a relatively thin mantle of drift thereon, obliterating the minor branches of the drainage systems but leaving the main valleys and major branches only partly filled and that the amount of erosion which has occurred since the disappearance of the last ice sheet has been relatively insignificant. The small amount of this erosion as compared with that in the Kansan area seems to the writers to indicate that the time since the disappearance of the ice from the Iowan drift area could not have been nearly so long as post-Kansan bime. They therefore regard the topographic character of the Iowan area as a whole as one of the evidences of a post-Kansan slaciation of this area. 


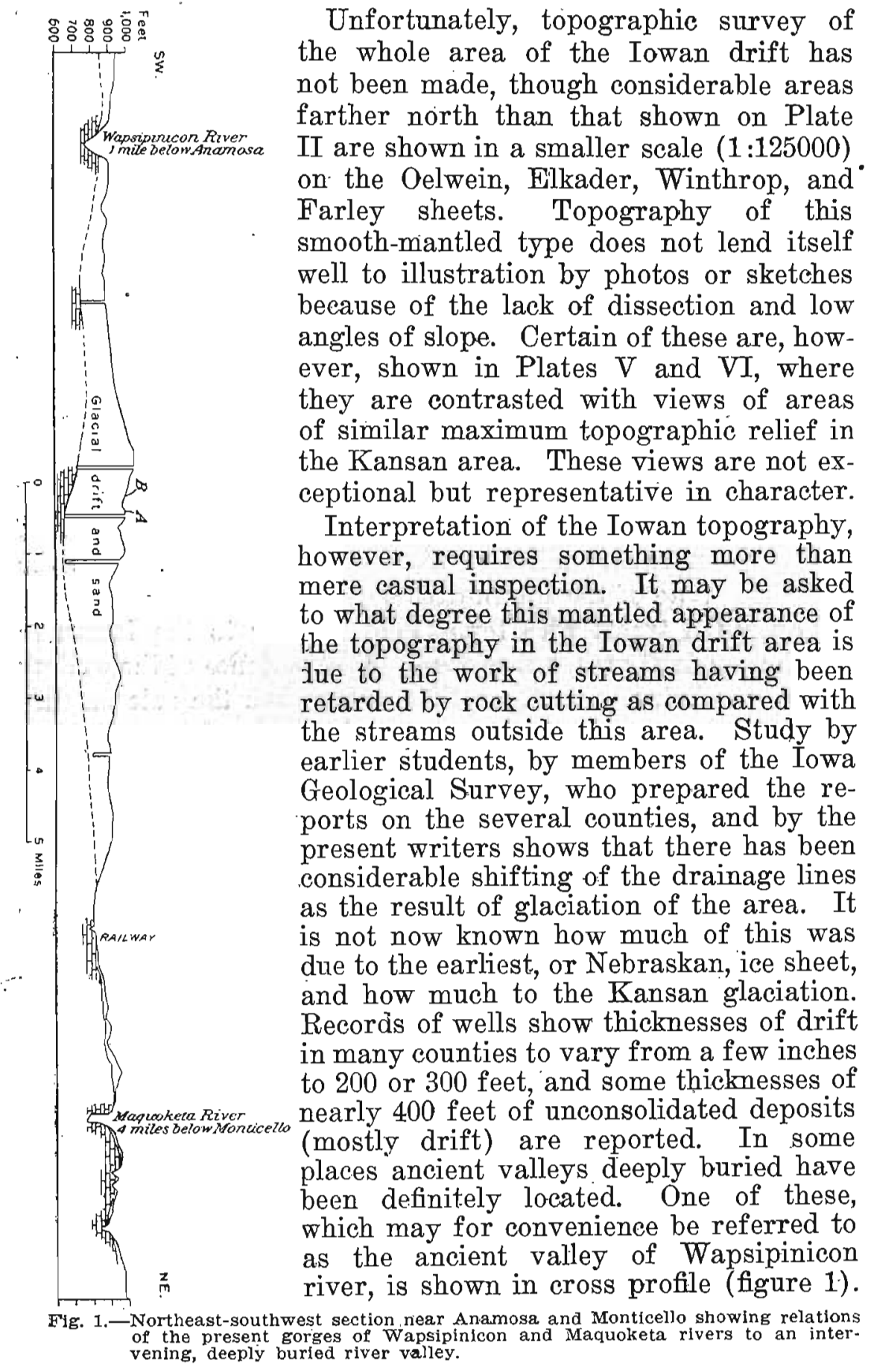



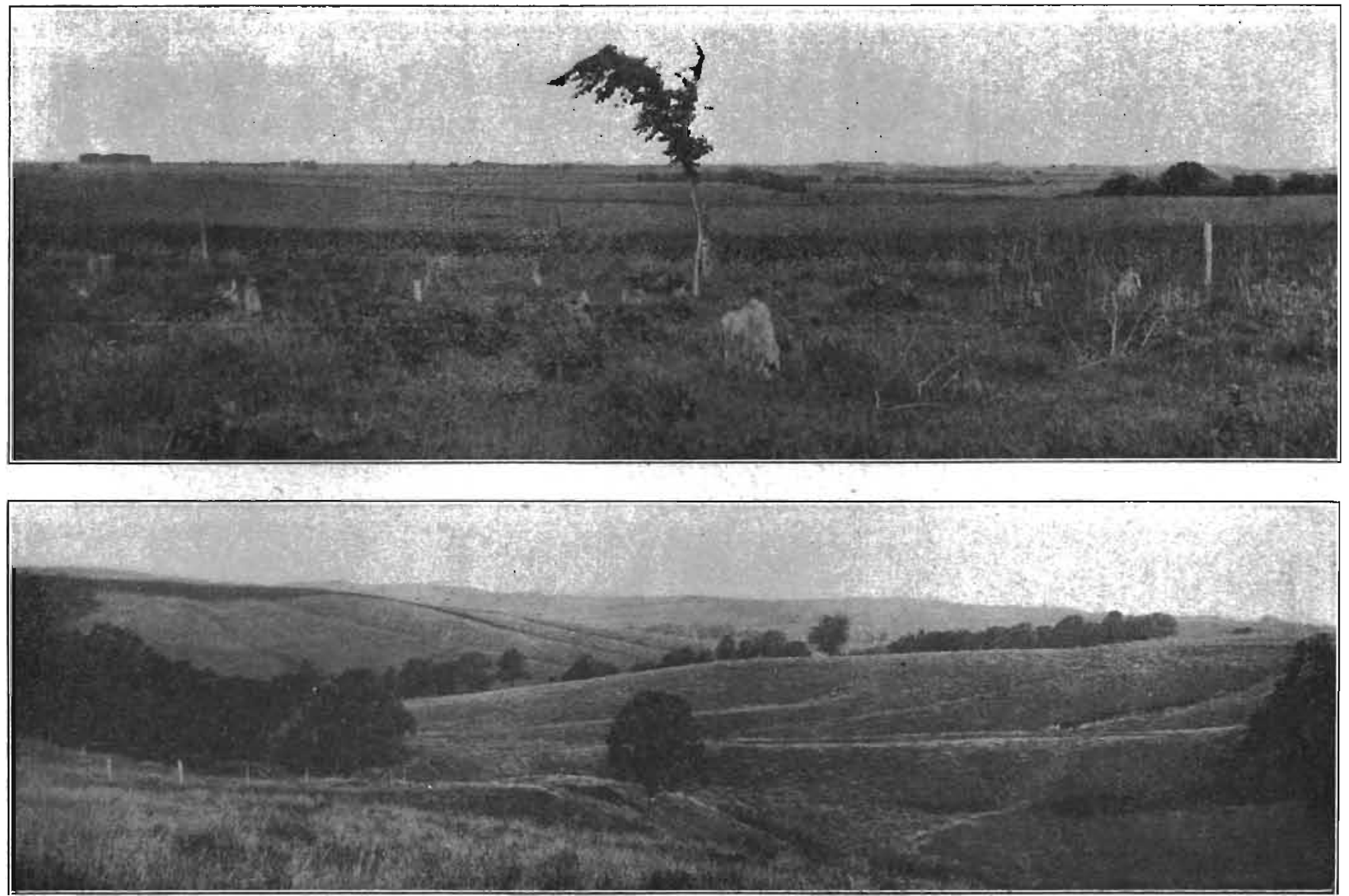

Compared topographies of the typical Iowan drift plain (A, south of Waterloo, Black Hawk County, Iowa) and the dissected Kansan drift plain (E: northwest of Oxford Junction, Jones County, Iowa. 


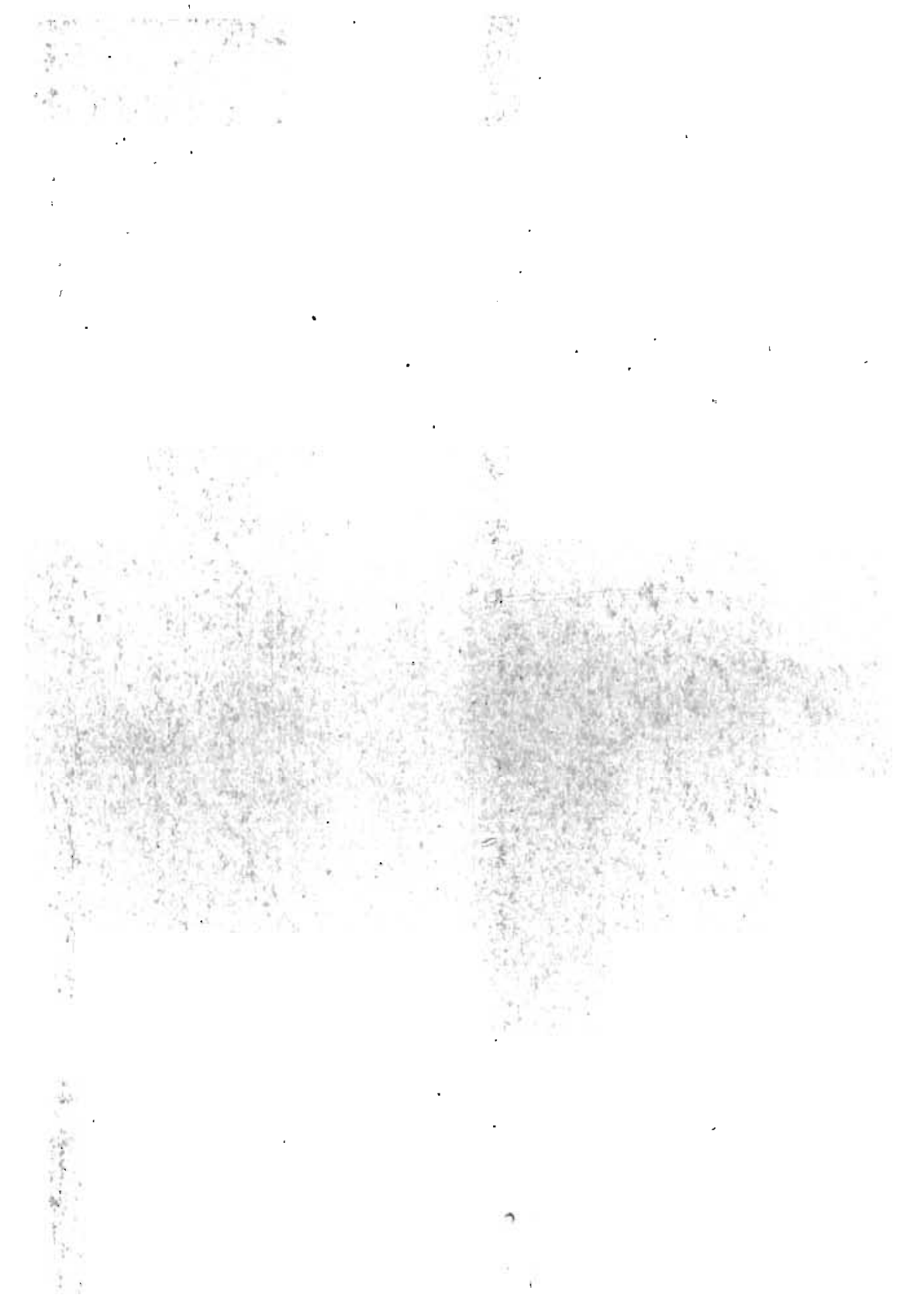


The relations in the case of this stream and of some others seem to indicate that the relocation occurred as the Kansan ice sheet melted away, leaving former valleys blocked. PostKansan time has clearly been long, for the streams of southern Iowa have accomplished a great deal of dissection of that area. In many places the present topography of the Kansan area has beeu carved wholly in drift. In many other places, however, the streams after eroding the drift have cut deeply into, and removed large amounts of the older rock.

The rock underlying the Kansan drift area is largely Carboniferous shale and sandstone, but considerable limestone has also been encountered, especially in the lower courses of the rivers. In the Iowan area the drift is underlain chiefly by Silurian and Devonian limestones. The shales of southern Iowa may perhaps not have retarded erosion in that region as much as did the limestones in northeastern Iowa, but it does not seem probable that the greater dissection of the Kansan drift areas can be accounted for on this basis alone. In the belt of older drift between Mississippi river and what is mapped as the approximate east boundary of the Iowan drift, Maquoketa, Wapsipinicon, and Cedar rivers have cut gorges in the Niagaran limestone in Delaware, Jones, Jackson, Cedar, and Johnson counties apparently in post-Kansan time. The depth of cutting in rock ranges from 50 feet or less to about 125 feet. These gorges head back some distance into the Iowan drift area. Closely bordering these gorges on either side are sharply dissected tracts, but the tributaries are in general short and the lateral gorges soon head at rock sills in the lower parts of the broad open swales. This latter is true of the headwaters of the Volga, Turkey, and Upper Iowa rivers also.* This gorge-cutting must have had a considerable retarding effect on the work of the streams, but even so it is doubtful if the lack of dissection in the upper stream courses in the Iowan drift area can be accounted for by this retardation.

\footnotetext{
"In studying the sharply dissected topography in these areas, as shown on the topographic maps, some allowance must be made for the plling up on hills and sharpening of slopes by deposition of the loess subsequent to the Iowan stage of glaclation in the wooded belts bordering these streams. It is not so much a case of the tion in the wooded belts bordering these streams it is not so much a case of the it is of the building up of hills of eolian deposits bordering the streams where the brush and trees so retarded the winds as to cause deposition of the dust swept off the prairies.
} 
Owing to the close similarity in composition of the Iowan and Kansan drift sheets, as shown in a later connection, the approximate limits of the Iowan glaciation are necessarily largely determined on the basis of topography. The boundary has in general been placed where the smooth swale topography on the one hand gives place to the sharply dissected topography on the other. In the study in the field it was found that the eastern boundary as mapped by the Iowa Survey in any given valley, such for instance as that crossing Lime creek west of Hopkinton in southern Delaware county, had been placed at the point where the stream ceases meandering from side to side in the bottom of a broad open swale and begins cutting sharply downward into the Niagaran limestone. Below this point the stream flows in a constricted gorge whose sides are picturesque castellated cliffs of limestone, in places nearly 100 feet in height. The contrast is very striking and questions at once arise in the mind of the critical observer, "Do the broad, open swales forming the upper parts of valleys such as Lime creek, with their long, smooth undissected slopes, represent a young topography due to mantling by a post-Kansan drift sheet, or, is it in reality an old erosion topography in an area which has been rejuvenated and where the newer cycle represented by the gorge cutting has as yet advanced only so far up stream as the present topography indicates?"

While no satisfactory answer to this question was found on the basis of topographic configuration alone, there are several considerations which seem to the writers to indicate that there has really been mantling of a maturely eroded topography by a post-Kansan drift sheet in the area mapped as Iowan drift.

It is true that the gorge-cutting represents a new cycle of erosion (post-Kansan probably) in each such valley and the gorge-cutting has progressed only to a point where the stream is now on rock in the bottom of the swale. If, however, the swale is simply a mature topography developed on the Kansan drift by erosion alone and not mantled by a later drift, the long, low slopes would seem to represent an older stage of erosion than that reached lower down in the valley. On this basis, considering the Iowan area as a whole as compared with the Kansan 
area to the south, we would be led to conclude that the heads of the tributaries of the upper Mississippi basin had reached a more advanced stage of erosion than the tributaries of the same system farther south. This is in itself improbable. One might suppose that the rock exposed in the lower parts of the swales retarded dissection in the upper parts, yet the angles of the side slopes range from $2^{\circ}$ to $8^{\circ}$, quite adequate for dissection if the valleys are old enough. In fact, it is surprising that they have not been cut by ravines since the Iowan ice disappeared. This may, indeed, afford ground for an opinion that some unknown factors are involved. One might also suppose that the drift, being more readily eroded than the limestone, would permit a mature stage of erosion to be reached in the drift of the upper part of the valley while the stream was yet cutting the constricted gorge in limestone in the lower part. It is to be noted, however, that the same relations of drift and limestone occur in the Kansan area to the south, yet there is, in general, so far as the writers have seen, no such combination of broad swales and low slopes on the upper stream reaches with sharp gorge-cutting lower down. As shown in Plates $\mathrm{V}, \mathrm{B}$ and VI, $\mathrm{B}$ and as described above, the heads of the streams in the Kansan area are minutely-branching, sharply-cut, Vshaped ravines scoring the slopes at frequent intervals. The. smooth swale topography so prevalent in the Iowan area seems to the writers to correspond very closely to what one would expect if a maturely dissected area were overridden by a readvance of the ice and left mantled with a drift sheet of moderate thickness. Besides the definite evidence of the presence of a post-Kansan drift sheet it is shown in a later connection that, subsequent to the cutting of the gorges; gravels were washed into and through them and deposited. These gravels, which may be regarded as outwash from the Iowan ice sheet, have since been largely removed by erosion so that in places only remnants are found as terraces bordering the streams. The topographic condition of the Iowan area taken in connection with the direct evidence, presented later, of the presence of a thin drift sheet apparently of post-Kansan age and of outwash gravels to be correlated therewith, seems to the writers 
to make the case for the Iowan stage of glaciation fairly strong. The only other alternative seems to be that in their study of the topography some very important factor has been wholly left out of the consideration. It is not clear, however, that this is the case.

The occurrence of broad interstream areas which seem to have been covered by the Iowan ice sheet between the dissected belts bordering parts of Maquoketa, Wapsipinicon, and Cedar rivers leads to the inference that the Iowan ice really extended into the gorges, but that the ready avenues of escape for the glacial water resulted in most of the somewhat meager drift being swept down the valleys by the streams and in such as remained being left mostly as waterlaid sand and gravel. The lobate margin of the Iowan drift as mapped by. Doctor Calvin and his associates gives to the reader the impression that the margin of the ice was actually similarly lobate at its maximum extension. It seems impossible, however, to think that the ice occupied the interstream uplands and did not extend down into the valleys which were in reality considerably lower, especially before the bordering loess hills were deposited. The writers have not made careful and detailed search of these valleys for remnants of the Iowan drift, but it seems necessary to conclude that the ice really lay in these valleys and thus a generalized boundary of the area covered by the Iowan ice sheet if it includes most of the lobate drift tracts which have been mapped, should extend across the intervening valleys with their dissected border belts. This is discussed in a subsequent connection. (see Chapter VIII).

While the prevalent topographic character of the Iowan drift area is such as appears to have resulted from the mantling of a maturely developed, post-Kansan, erosional topography, there are exceptional areas where there is considerable sharp dissection and where the topography appears not to have been mantled. Reference has already been made to the principal areas of this kind along Maquoketa, Wapsipinicon, Cedar, and Iowa rivers. There is an isolated tract of this sort on the Maquoketa in the northwestern part of Delaware county, north of Dundee. The stream here flows through a picturesque wind- 

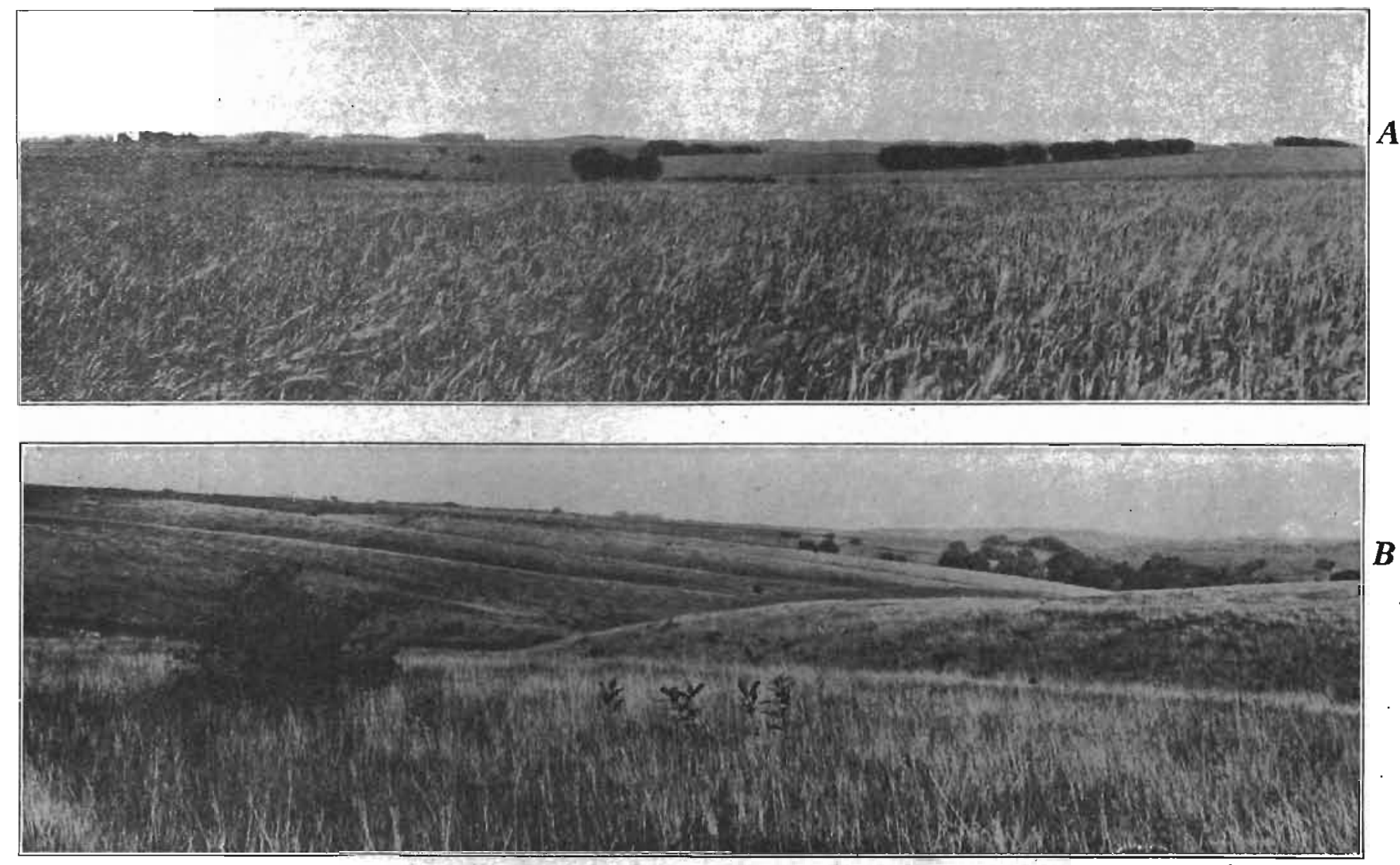

Compared topographles of the typlcal Iowan drift plain (A, near Van Horn, Benton County, Towa) and the dissected Kansan drift plain (B. west of Washington, Iowa). 
,

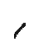


ing gorge 50 to 150 feet in depth cut in the Niagaran limestone. On the melting of the ice sheet the stream was superimposed on a buried ridge of limestone. The subsequent work of the stream has developed the gorge. If the shifting was the work of the Kansan ice it seems necessary to suppose that the Iowan ice filled the gorge, but did not leave it buried in drift. On the other hand, it may be the gorge is of post-Iowan age, but this seems doubtful. A similar rock gorge is traversed by Cedar river at and above Osage.

Some loess-covered hilly tracts have been shown on the maps of the Iowa Survey as loess-covered Kansan drift. None of these areas is so high that it can be supposed that the Iowan ice did not cover it. It is hardly possible to conceive of an ice sheet competent to extend 150 miles or more southeastward in Iowa and to spread over an area of 9,000 square miles which was so thin as not to cover hills 100 feet or less in height. On the other hand, the load of drift carried by this ice was probably not very great and though covered by ice the hills may well have been unmantled or thinly mantled with Iowan drift, as was clearly the case in some other places. The steep slopes of these hilly tracts would favor erosion and the subsequent removal of thin drift. Moreover, their mantle of loess does not everywhere permit a determination of just what drift is present. Such tracts occur in Mitchell, Butler, Bremer, Black Hawk, Benton, and Linn counties. An exposure on one such hilly tract southeast of Hampton showed two feet of till, presumably Iowan, overlying much weathered drift or "gumbo," probably Kansan.

\section{CHAPTER II}

\section{THE UPPERMOST TILL OF THE IOWAN AREA.}

If the topographic configuration of the Iowan drift area is the result of post-Kansan glaciation and the deposition of a mantle of till on the dissected surface of the Kansan, it is to be expected that the uppermost drift of the Iowan area would show less modification by weathering than that of the parts of the Kansan drift area immediately adjacent. Conversely, if the 
drift generally exposed at the surface throughout the Iowan area shows on the whole less modification by weathering than does that of the Kansan area, it may be regarded as one evidence of post-Kansan glaciation of the area.

It may be contended that, unless the Iowa drift has distinctive lithologic or other characters by which it can be identified in every exposure (and unfortunately it has not), or unless it is everywhere distinctly separated from the underlying drift by a soil or weathered zone (which, of course, is not the case with any drift sheet), it is not permissible to infer that the uppermost drift at all, or even most, places in the area is the latest drift of the area. Thus any generalized statement of the character of the uppermost drift of the Iowan area might be said to be merely a description of the upper part of the Kansan drift, which is believed to be the main drift sheet in northeastern Iowa, or be a combination of data from exposures, some of them in Iowan drift and some of them in Kansan, and so not be really representative.

One familiar with the usual conditions of exposure of glacial deposits and knowing how far short of what are theoretically desirable for the proper discrimination of different drift sheets are these conditions must admit the justice of such statements. These limitations apply, however, in all drift areas and are not confined to the Iowan drift area. There are places in the Iowan area where the total of all drift deposits remaining is very small, in spot's nothing at all, yet the writers are quite firmly of the opinion that an ice sheet of sufficient volume to spread so far south and cover 9,000 square miles in northeastern Iowa could not have failed to transport a considerable amount of drift and to have left a till sheet which was composed of more than patches of material derived from the deeply weathered. upper part of the Kansan drift. There should be a till sheet of at least moderate thickness spread generally over the area though perhaps locally very thin or even absent in spots. If the topographic configuration is due to mantling of a dissected Kansan topography, as the writers believe it to be, there must have been enough glacial abrasion and deposition of drift to produce the mantling. It is, therefore, fair to expect, if a large 
number of exposures are examined and if a large number of borings are made, well distributed over the smoothly mantled area, that a compilation of the data will give a fairly good idea of the general character of the latest drift of the area, and of the amount of its modification by weathering.

Scores of exposures throughout the lowan drift area were studied, and the constitution, physical features, and degree of modification of the till by weathering were noted. The recent improvement of wagon roads, construction of interurban electric railway lines and the regrading of the Chicago, Milwaukee and St. Paul railway have afforded many new exposures. The majority of the cuts in this area are less than fifteen feet deep, and few are so much as twenty feet. On account of the small amount of dissection of the Iowan area, there are localities where road cuts or excavations of any kind are few. In such areas a two-inch auger eight feet in length was used for making test borings.

The following is a generalized section of the deposits shown by these exposures:

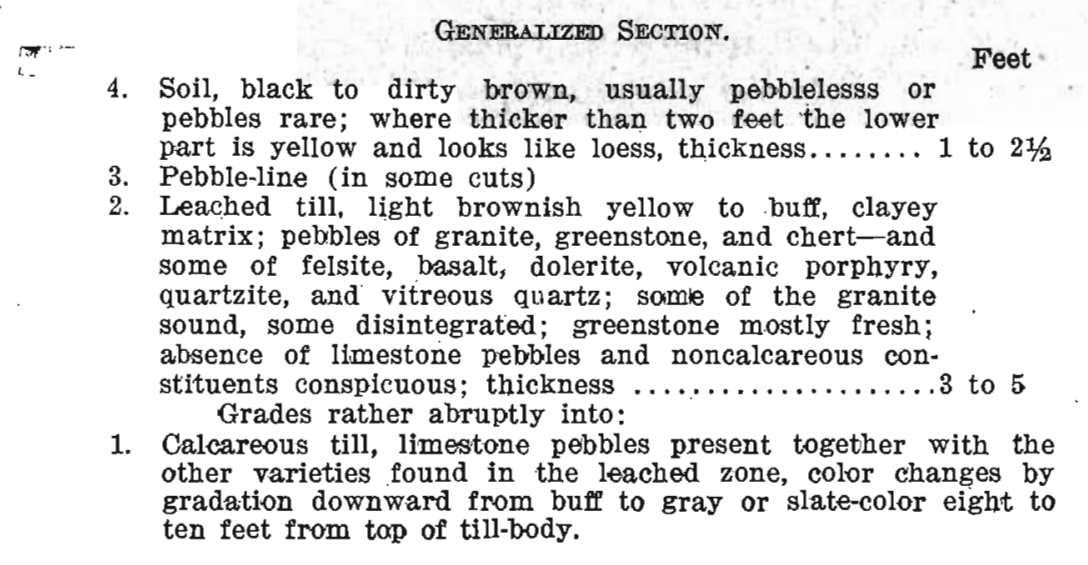

The Lithology of the Iowan Drift and Its Comparison With Other Drifts.

Rough determinations of lithologic composition were made by collecting and sorting pebbles from numerous exposures of each of the following drift sheets in Iowa, the Nebraskan, Kansan, Iowan, and Wisconsin drifts. The results of these, together with numerous similar estimates made by R. T. Chamberlin 
in 1907, are presented in tables in Appendix A for ready comparison. From Table 2 it will be seen that the pebbles of the unleached Iowan drift comprise mainly granites, greenstones, limestones, schists, quartzites, quartz, cherts and sandstone. It will be noted that the percentage of each constituent varies considerably from place to place, and that the general composition of this drift is not distinctive. This being the case, unless the two drifts are exposed in the same section with a weathered zone or interglacial deposits olearly marked between, one cannot always be sure that any particular section is in Iowan till and not Kansan. The only lithologic distinction which the Iowan drift sheet possesses seems to be the greater abundance of large granite bowlders in the eastern and central parts of the area. These bowlders are considered in Chapter V.

In general, however, it may be stated that the limestone content of the Wisconsin drift is higher than that of any other (See Table I); that the formation of ironstone concretions in the altered zone and the concentration of calcium carbonate in the unleached zone of the Iowan drift are less notable than is the case with the Kansan drift. ${ }^{5}$ The latter point suggests that the Kansan drift has undergone more prolonged weathering than the Iowan.

THE OXIDATION OF THE TILL.

In most places oxidation to a buff or bright yellow tint has extended to depths below the reach of the eight-foot auger. Yet in many places bluish gray unoxidized till was reached in boring. As seen in cuts, oxidation was found, in most places, to have changed the original bluish gray or drab-gray color of the till to light buff to depths somewhat greater than the leaching had extended, that is, usually to depths of seven to ten feet. Below these depths the color gradually changes. The color in the oxidized part of the till generally ranges from light buff at the bottom to brown at the top. In many places, as in Bremer county, the upper part below the soil is a bright ocher-yellow, but rarely is it orange and seldom is there a distinct reddish tint as in the Kansan ferretto. In some places the bluish gray

-It should be noted that the true percentages of clay ironstones and calcareous concretlona are nnt pemerally shown in tho tahles na antimates since in collecting pebbles, the writers almed to avold these secondary constituents. 
till is considerably more dense and hard than the oxidized and leached till and grades below into dense, hard, dark, slatecolored till. In these instances the unoxidized till, at least, is probably Kansan.

If the interglacial deposits or the red ferretto characteristic of the top of the Kansan have been removed by erosion and a deposit of Iowan till left instead a given cut may show buff Iowan till over buff Kansan till with no apparent break between. This is one of the factors that makes the determination of the exact limits of the Iowan drift well-nigh impossible. It certainly is not safe to regard all the buff or yellow till as Iowan and only the blue-gray or blue-black unoxidized part as Kansan, as seems to have been done in some cases.

Fortunately, however, as described on page 92 there are a number of places where the weathered zone and interglacial soil at the top of what is regarded as Kansan drift are well preserved with an overlying deposit of till, presumably Iowan.

THE EFFECTS OF LEACHING.

Examination was made of sixty-five exposures which showed the change from calcareous to leached till. The clayey matrix was tested with cold dilute hydrochloric acid. The limestone pebbles were present in the former but mostly absent from the latter. As shown in Table 3, Appendix A, seven estimates where the pebbles were taken only from the leached upper part of the drift show an average of but three per cent of limestone and dolomite, while the percentages of the relatively insoluble constituents were correspondingly higher.

Besides examining the exposures, 250 auger borings were made, where cuts were not available, to ascertain the depth of the leached zone and character of the till. One hundred and sixty-five of these' were in the interior of the area and eightyfive nearer the border.

Following is a tabulation of the results obtained by examining the exposures and making auger borings: 


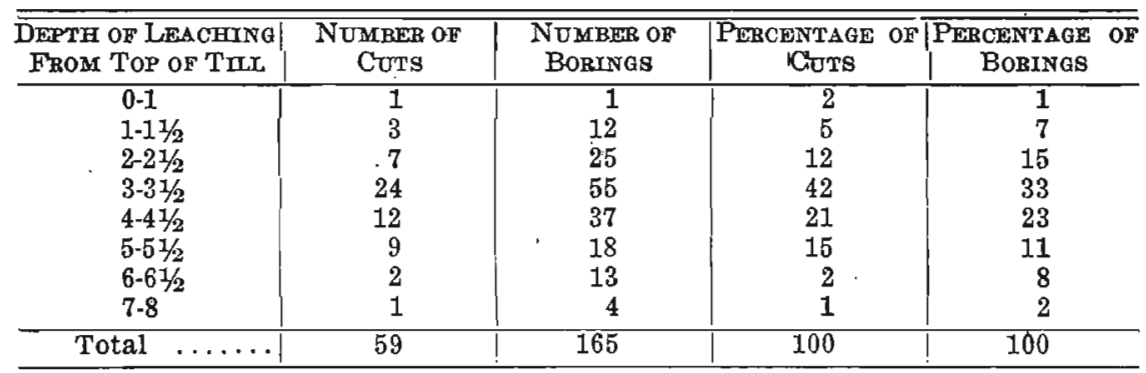

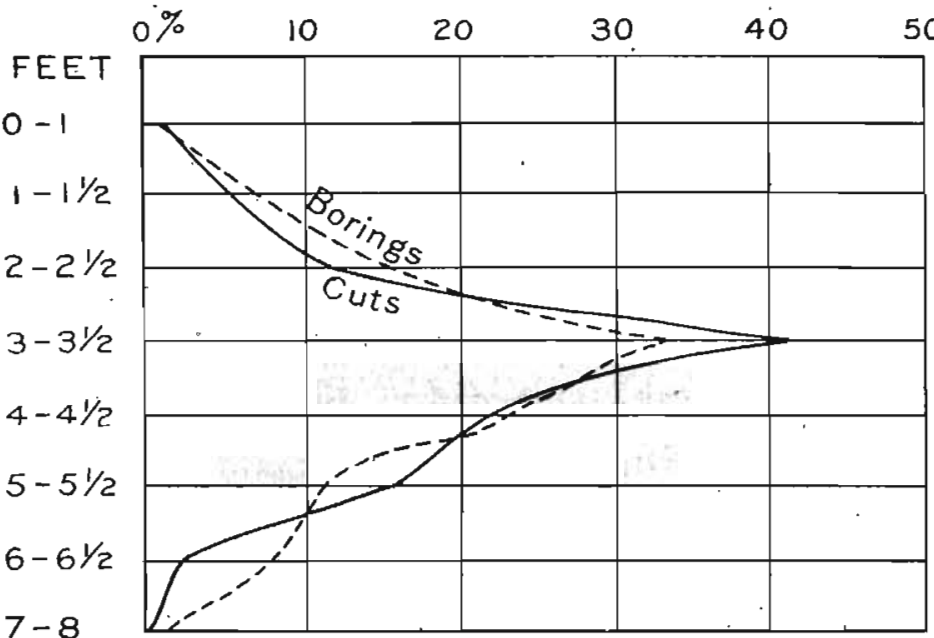

Fig. 2.-Diagram of percentages of cuts and borings showing different depths of leaching of the uppermost till at various places in the area of the Towan drift.

The curve in figure 2 represents graphically the foregoing results.

This compilation shows that the larger number of cuts and borings give a depth of leaching of three to three and one-half feet; that seventy-eight per cent of the cuts and sixty-seven per cent of the borings indicate a range of depth from three to five and onè-half feet; and that only one per cent of the cuts and two per cent of the borings showed as much as eight feet of leaching.

In the border belt the depth of leaching is less uniform and averages somewhat more. Fifty-four per cent of the borings showed the depth of leaching as four to six and one-half feet, thirty-two per cent less than four feet, and fourteen per cent as much as seven and one-half feet. 
The overlying loesslike clay.-Generally soil and loesslike clay one to two and one-half feet thick overlie the till of the Iowan area. This deposit is not included in the measurements of leached till. It appears to be a thin mantle of loess which has largely lost some of its typical character as the result of leaching, freezing and thawing, burrowing of animals, the influence of vegetation and mixing with humus in the upper foot or so. Where the deposit is more than two and one-half feet thick, its lower part is identical in character with loess. As seen in cuts it is generally separated from the till by a distinct line of pebbles, which are probably the residue from wash and winderosion of the upper part of the till.

If this thin coating of loess was deposited as calcareous material immediately after the deposition of the till, its thickness should be included in the depth of leaching which has taken place since the till was deposited. If it was added later as noncalcareous material derived from the weathered surface of the till, then its effect on the leaching of the underlying till has been slight. A part of it may have had the former history, a part of it the latter.

COMPARISON WITH THE KANSAN TILL.

The oxidation of the Kansan drift.-The uppermost till of the unquestioned Kansan area was studied in railroad sections and road cuts to the south and east of the Iowan drift area. Its oxidation, decomposition, and leaching were carefully noted: The change in the Kansan drift as the result of oxidation differs from that of the uppermost drift of the Iowan area in two particulars, -in degree and in depth. In most of the places seen the Kansan drift is overlain by loess. The prevalence of a reddish brown or dark brown ferretto zone at the top of the. till and beneath the loess is a conspicuous phenomenon. This ferretto, which averages one to one and one-half feet thick, consists of a dense, sticky clay containing many decomposed granites, greenstones, and other igneous rocks, together with quartzites, quartz, cherts, and clay ironstones. It grades downward into brownish and yellowish leached till. The material has the appearance of being the relatively insoluble residuum of prolonged leaching, oxidation, decomposition, and dehydration 
of a somewhat greater thickness of the upper part of the till. Its advanced state of decay matches its setting in the much eroded Kansan area. In many exposures the ferretto is cut off well up in the eroded slope as though it had been formed before the present stage of dissection was reached.

The ferretto band is fairly persistent in the crests of the ridges throughout those dissected parts of the Kansan drift area which were visited by the writers, and it is strongly in contrast with the brownish yellow color of the upper part of the drift in the Iowan area. The ferretto was seen within the boundaries of the Iowan area, in three or four places only. At one or two of these there was evidence of mechanical mixing with fresher till, as if the ferretto had been disturbed by an overriding ice-sheet. The other cases were in isolated localities of sharp; mature erosion, where the topography lacks the mantled aspect.

Not only is there a significant difference between the degree of oxidation of the uppermost till in the Iowan area and that of adjacent parts of the Kansan areas, but also in the depth of oxidation. The Kansan drift is oxidized to depths of fifteen to twenty-five feet below the base of the loess, as compared with eight to ten feet for the Iowan drift.

While the writers regard this sort of evidence as entirely legitimate, they do not think these measurements, those given above, or those following, can be applied indiscriminately in other areas. The similarity in climate at present between northeastern Iowa and adjacent parts of southern Iowa and Illinois seems to warrant direct comparisons of the amount of modification by weathering of the several drift sheets. Going to another region, however, as, for example, to the drier climates farther northwest, the same differences may not be found. If contrasts in degree and in depth of oxidation of deposits in two areas, lying side by side, are to be regarded as at all indicative of difference in age, the data cited are certainly significant. The strong oxidation is found where there is the deeply dissected topography of the Kansan, the moderate oxidation is associated with the mantled and little eroded topography of the Iowan area. This evidence seems to support the conclusion of difference in age reached from the study of the topography. 
The leaching of the Kansan drift.-If mature erosion, the presence of a ferretto, and greater depth of oxidation distinguish the drift of the Kansan area from that of the Iowan area and indicate a greater age for the former, the leaching of the Kansan till should at least be consistent with this view.

In critically examining data bearing on the leaching of the Kansan till, attention to the topographic position of the exposure is important. In a sharply dissected topography, the leaching of the till on the lower slopes must date from the time that the drift in that topographic position was brought within the zone of leaching by the removal of the overlying material, i. e., from a time when most of the erosion had been accomplished. The diagram (figure 3 ) of a specific case illustrates

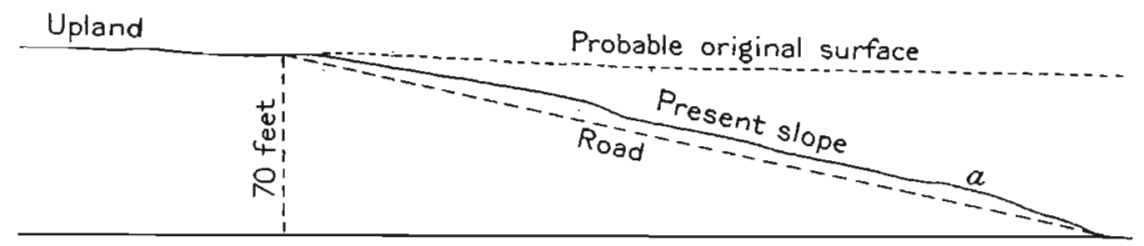

Fig. 3.-Diagram of valley slope in Kansan drift area four miles northeast of Victor (Iowa County. Hartford township; Township 80 North, Range 12 west. east line southeast quarter section 3 . a. Position of road cut showing till leached to depth of five feet.

a prevalent condition. A road cut at $a$ shows a leached zone of five feet. Obviously, this thickness may have been added to by deposition or subtracted from by slope-wash. But if we assume that the thickness is a true record of the depth of leaching in place, it still can not be taken as indicative of the full age of the drift but rather as a measure of the time since that particular portion of the drift was subjected to leaching.

One must discriminate also in interpreting the data collected from railroad cuts, similarly located. To illustrate again, reference may be made to a Chicago, Milwaukee and St. Paul railway cut in a locality of sharp dissection in Tama county, west of Vining, Otter Creek township, southwest quarter of section 13. The cut is 150 yards long, has a maximum depth of 25 feet, and transects the lower parts of two long spurs. In vertical section the relations are as follows (figure 4).

At $a$ a ferretto and a leached zone of till four or five feet thick lies beneath calcareous loess. At $b$ and $b^{1}$ these are absent and 
NW.

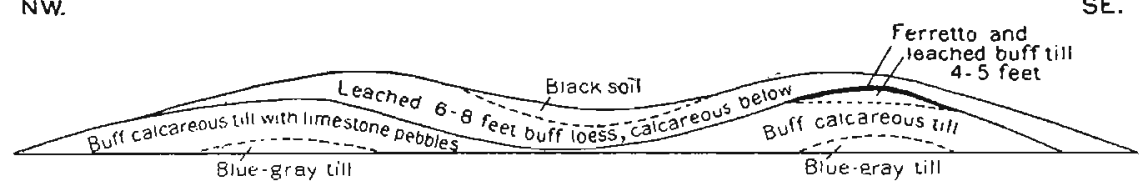

Fig. 4.-Dlagram of drift exposed in Chicago, Milwaukee \& St. Paul Railway cut three miles west of Vining, Tama County, Iowa, showing relation of loess to weathered and unweathered Kansan drift. Length 450 feet. Holght 25 feet.

the calcareous loess rests directly on calcareous till containing limestone pebbles. The relations at $a$ record an interval of leaching and oxidation between the development of the surface of the till at this horizon and the deposition of the overlying loess. This record, however, covers only a fraction of the interval between the deposition of the till and the deposition of the loess. It lacks at least the time consumed in the erosion of the original drift plain down to this horizon. Furthermore, the difference in relations at $a$ and $b$ are suggestive of the unreliable character of the data even for the interval between the slope development and the deposition of the loess. If the relations at $b^{1}$ only were known, there would be absolutely no record of the interval of leaching. Obviously, erosion; or slope-wash, at $b$ and $b^{1}$ overtook and surpassed the rate of leaching so that the weathered zone was removed before the loess was deposited.

It is evident from such conditions that the depths of leaching ascertained from exposures on slopes may be much less than the actual total amount of leaching of the Kansan till. Better places for such measurements would probably be in cuts through the upland divides, but such are few.

A cut forty-five feet deep, about three-fourths mile east of Vining, situated almost half way up the slope of a spur, shows as much as seven feet of leaching at the top of the till below calcareous loess, which in turn is overlain by leached loess. But even here the top of the till is considerably below the general upland level and its surface is rounded.

West of Melbourne, Marshall county, there are three cuts within four miles, similarly situated topographically, which show a like depth of leaching, and four others higher up on the slopes of spurs, which show leaching to depths of twelve, thirteen, twelve and eleven feet, respectively. In all of these cuts the leaching took place before the loess was deposited. 
Two and one-half miles west of Rhodes, Marshall county, at the edge of the Wisconsin drift sheet, in a cut seventy feet deep, ten feet of nonoalcareous gumbo and ten feet of leached Kansan till overlie calcareous Kansan till and underlie loess and Wisconsin drift. If the gumbo is the product of weathering of the Kansan till, as is believed by some recent workers, the leached zone in this case would be at least twenty feet.

If the gumbo is really the concentration of the least readily soluble constituents of the upper part of the till, i. e., the residuum of long leaching, each foot of its thickness represents more than one foot of the original till before the soluble parts were removed. Whether or not the gumbo is such, it seems clear that the ferretto zone is the result of such concentration, together with oxidation, and represents a somewhat greater thickness of unleached till.

It appears that some appreciable part of the till is composed of the soluble part of the limestone pebbles, since these comprise nearly fifty per cent of all the pebbles in the drift and with these goes the calcareous rock flour in the matrix of the till. If accurate determinations were being made of the total depths of leaching, some small amount should be added to the present thicknesses of the leached zone. In the rough determinations made in this investigation, however, this factor may be omitted.

Comparing then the leached zone of the Kansan drift near the original upland in adjacent areas with the leached zone in the Iowan drift area, depths of eleven to thirteen feet in the former as compared with three to five and one-half feet in the latter emphasize the greater age of the Kansan drift over that of the Iowan.

But yet the whole difference has not been pointed out. The rate of leaching undoubtedly decreases with depth, due to (1) the less amount of percolating water on account of capillary action bringing a part back to the surface;(2) the slower movement of the ground water with increased compactness, and (3) the decreased solvent action of the water as the result of the dissolving of some materials during descent. Hence, the relative length of time is probably something more than the ratio of the foregoing figures. 
Another point of importance remains to be noted. The leached zona of the Kansan drift lies beneath calcareous loess, which in turn is overlain by leached loess five to ten feet thick. This stratigraphic relation shows that the period of leaching of the Kansan drift is separated from the present by an interval of loess deposition and of subsequent leaching of the loess to depths varying from five to ten feet. In most of the Iowan drift area, the leaching of the drift has continued to the present without. much interruption. Therefore, in order to make proper comparisons, the equivalent of the leaching of the loess should be added to the leached zone of the Kansan.

The phenomena of weathering, therefore, seem to indicate that there is in northeastern Iowa a drift sheet which is young as compared with the Kansan drift.

COMPARISON WITH THE WISOONSIN TILL.

The Wisconsin till was examined for purposes of comparison at several points from Cerro Gordo county south to Jasper county and along the Chicago, Milwaukee and St. Paul railway across the southern part of the Wisconsin drift plain.

In practically all places the oxidation of the Wisconsin till is to a light buff tint, and the leached zone is in general two to three feet deep. In many places limestone pebbles are present at or near the surface: Locally there are occurrences of loess on the Wisconsin drift but the amount is generally negligible. The topography of the Wisconsin is typically glacial and the amount of erosion is slight except near major streams. There seems to be little ground for doubt that the Iowan drift is distinctly older than the Wisconsin. 


\section{CHAPTER III}

\section{THE SUPER-KANSAN “GUMBO,” ITS CHARACTER, RELA- TIONS, AND SIGNIFICANCE.}

\section{In the Kansan Drift Area}

An overlying later till may not be distinctly separable in many places from an underlying earlier till, especially if no interglacial deposits or weathered zone have survived the abrasion of the later ice sheet. Nevertheless, it would be strange, if, in an area as large as 9,000 square miles, and with the Iowan drift as thin as has been described there should not be found unmistakable evidence of separation from the Kansan till.

A number of exposures have been found in northeastern Iowa showing what appear to be remnants of the super-Kansan "gumbo" with, in some places, a black carbonaceous layer representing an old soil at the top and above this a later till of moderate thickness. In these places the supposed Iowan till is clearly separated from the older drift. The character, distribution, and mode of origin of the super-Kansan "gumbo" of southern Iowa are to be discussed by Doctor Kay in a forthcoming paper. A preliminary paper has been published already by him. ${ }^{\circ}$ So important are the occurrences of "gumbo" of this age to the question of the differentiation of a post-Kansan drift in northeastern Iowa that a brief description of "gumbo" exposures observed by the writers is presented here.

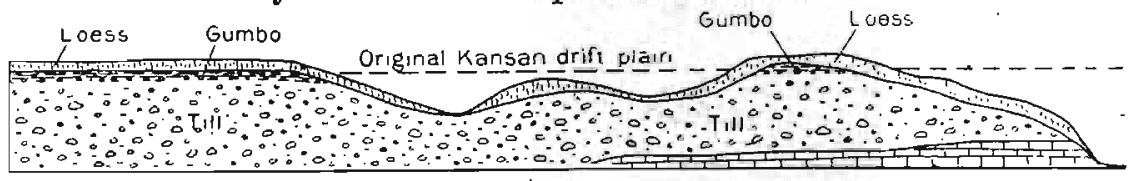

Fig. 5.-Diagram showing relations of super-Kansan "gumbo" and of loess to remnants of the original Kansan drift plain.

Overlying the Kansan till on the uplands, that is, on remnants of the original Kansan plain (figure 5) throughout much of southern Iowa is a deposit of clay which, for want of a better name, may be called "gumbo." This clay is dense, sticky, and

\footnotetext{
-Kay, Geo. F-, Some Features of the Kansan Drift in southern Iowa: Bull. Geol.

Soc. America, Vol. 27 , pp. 115-117. deposits. See Kay, Geo. F. Gumbotil, a new term in Pleistocene geology: Science, N. S., Vol. XLIV, pp. 637-638, 1916.
} 
very slippery when wet. It is generally noncalcareous and dull gray in color. Sometimes the color is gray mottled with brown and the upper part is oxidized to a reddish or brownish tint. It has not the loose porous texture of loess and the sun-dried face of the exposure generally differs from that of loess in being checked by sun cracks. A fresh-fractured surface of a lump of "gumbo" often shows minute pellets, a millimeter or so in diameter, of clay, or sometimes of oxide of iron or manganese dioxide, such as characterize the so-called "buckshot" clays. Removal of the pellets leaves the surface pitted with little concave depressions.

There are places where the "gumbo" is rather sandy, though even here a sticky clay matrix makes the grains adhesive rather than loose; so also the clay may contain, in patches, small angular bits of feldspar, quartz, and other minerals such as might result from the disintegration of included granite pebbles or bowlders. Some instances are reported by Doctor Kay of granite bowlders being included and still retaining their form though so much disintegrated as to be easily cut through by a pick or spade. The "gumbo" is nowhere very stony but it generally contains" scattered small pebbles, mostly less than one inch in diameter. These are predominantly of chert and quartz but with these are occasional crystallines and quartzites. An estimate of pebbles collected from a road cut in the "gumbo" one-half mile south of Russell, Lucas county, showed the following:

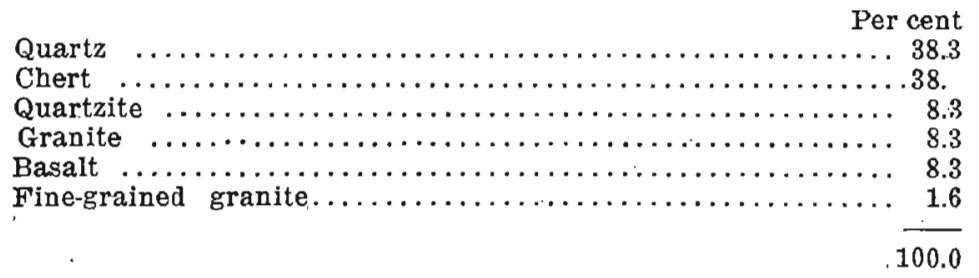

Careful examination of numerous exposures shows no lamination of the clay such as usually characterizes waterlaid silts and shows no definite line of demarcation separating this clay from the Kansan till below. The change from the stony till to the less stony "gumbo" above takes place in a narrow zone' but it seems clearly to be one of gradation. The till may be leached of its calcareous material for a few feet below the base of the 
"gumbo" or it may be highly calcareous nearly or quite to the narrow zone of transition. The limestone and dolomite pebbles and most of the crystallines become smaller and smaller from the base of the transition zone up into the "gumbo," where they disappear; and the few crystalline pebbles which remain are usually badly decomposed and are smaller and still fewer toward the top of the "gumbo." This condition gives rise to the suggestion that the "gumbo" is not a distinct and later deposit but that it is the residuum of thorough weathering and long leaching of the upper part of the Kansan till.

The "gumbo" where seen by the writers ranges in thickness from a few feet to eighteen feet. If it really is the residuum of the upper part of the Kansan till after the more readily soluble constituents have been removed by leaching, it evidently represents a very long time of exposure since the disappearance of the Kansan ice sheet.

The upper part of the "gumbo" is generally colored reddish or brownish as the result of oxidation and hydration and where the gray clay has been burned for brick or railroad ballast; it changes to a red color. The part of the till immediately beneath the "gumbo" is also generally oxidized orange, brownish, or buff, and the latter tint may continue downward fifteen or twenty feet before grading into the original blue-gray or blue-black color of the unoxidized till.

With some exceptions, which may be the result of redeposition, the "gumbo" lies on the upland remnants of the Kansan drift plain. It does not extend down the slopes but is cut off by erosion. From this it is inferred that the "gumbo" was developed (possibly when the plain was low-lying) before any considerable amount of dissection of the Kansan plain had been accomplished. If all these suggestions are really true, it is apparent that the interval between the Kansan and Mlinoian stages of glaciation, the Yarmouth interval, was of very long duration, for studies in southeastern Iowa and western Illinois (see page 199) show that the super-Kansan "gumbo" there underlies the Illinoian drift.

In the Kansan area, this "gumbo" lies on top of the Kansan drift, and near the Iowan-Kansan border it underlies loess. Wherever the loess is more than six or eight feet thick, its base 
is calcareous, whereas the "gumbo" is leached and the upper one foot or so is oxidized to a brownish gray with reddish specks scattered promiscuously. There is no doubt that the "gumbo" is much older than the loess.

These various questions will be considered by Doctor Kay in his forthcoming paper. Whatever may be the final conclusion. in regard to them, one thing seems to be clear, the "gumbo" has so wide a development on the remnants of the Kansan plain that whatever its origin it seems to mark fairly definitely the stratigraphic horizon of the original top of the Kansan drift, even in the Iowan drift area. ${ }^{8}$ The only qualification of this statement as far as the relations of the Iowan drift are concerned arises from the fact, (discussed in another connection) that a similar bed of "gumbo" occurs in places at the top of the Nebraskan drift. The finding of somewhat similar deposits at the top of the Illinoian drift while affecting the interpretation as to relative age of the Iowan and Illinoian drifts does not directly affect the question of the Iowan drift being a distinct post-Kansan drift sheet.

\section{In the Iowan Drift Area}

In the Iowan drift area a number of exposures of "gumbo," probably the super-Kansan "gumbo," have been observed, and overlying this is a deposit of glacial till. If this "gumbo" is really super-Kansan the drift over it is clearly the product of a distinct ice invasion of post-Kansan age. This upper till the writers believe to be the Iowan till. This "gumbo" is identical in character with that found on the Kansan of southern Iowa. It has, in places, a black carbonaceous layer, an old soil, at the top. So far as observed it is noncalcareous while the overlying till is in some places seen to be highly calcareous. At other exposures the drift is so thin that it has been leached of its calcareous constituents. The observed exposures of the "gumbo" are mostly in the higher parts of the Iowan drift area, in those places where it would be expected that remnants of the original Kansan plain might be preserved. These exposures are mostly in recentlymade cuts for electrio, steam, and wagon roads, so that but few

\footnotetext{
${ }^{3}$ For purpose of record and to make the data readily accessible for study, there are inserted in Appendix B notes on exposures of the super-Kansan "gumbo" in the area seen by the writers immediately south and east of the Iowan drift area.
} 
of them seem to have been observed during the earlier studies of the area and such as were seen were not recognized as having the significance now attached to them. Besides being observed in exposures, the "gumbo" was encountered in some of the borings made by the writers. These new items of evidence are important as lending definite support to the theory of post-Kansan glaciation in northeastern Iowa. Considering the fact that only a very small part of the roads of the Iowan area were actually traversed during these two field seasons, the study being in the nature of a review rather than a detailed survey, it is not remarkable that so small a number of exposures of the gumbo were found. Further examination throughout the area along the roads not already traversed may yield additional data: So important is the evidence in hand that detailed descriptions of the occurrences noted are given herewith. They may thus be compared with the descriptions of occurrences of "gumbo" in the Kansan area and in the Illinoian drift area. (See Appendix B.)

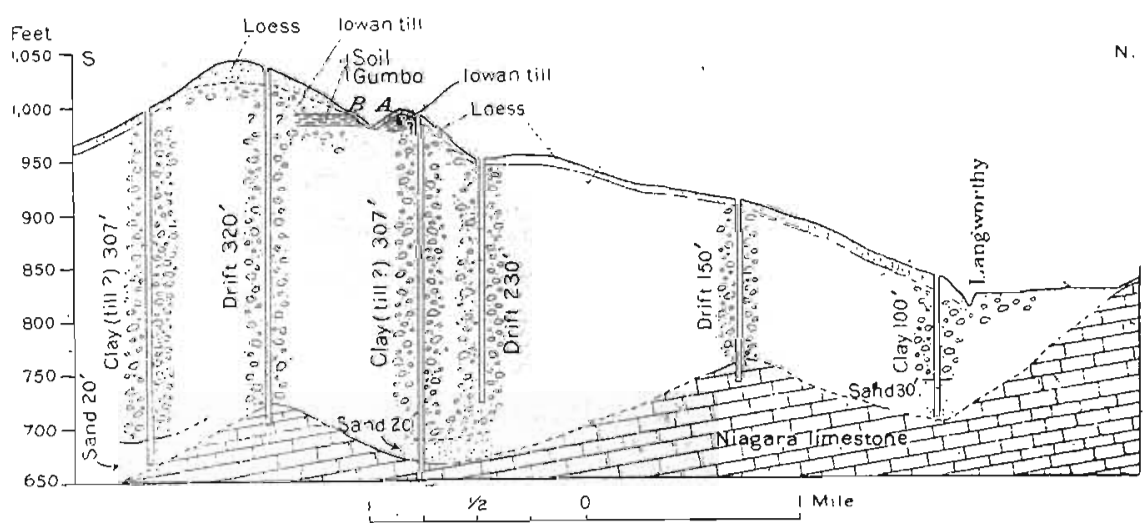

Fig. 6.-Diagrammatic section across ridge south of Langworthy, Iowa, showing relations of loess: (1) Iowan till; (2) Yarmouth soil and super-Kansan "gumbo"; (3) Kansan drift; (4) earlier deposits.

JONES COUNTY.

One of the most significant exposures is in Jones county on the top of the ridge between Monticello and Anamosa. The relations are shown in figure 6 . The general relation of this ridge are shown on a smaller scale in figure 1.

The exposure is south of Langworthy and about five miles northeast of Anamosa in the south slope of a lobe of the ridge, in 
Jones county, Wayne township, (Township 85 North, Range 3 West, section 30 near the middle of the north line). The beds exposed in the road cut and penetrated by boring with an auger are as follows (see A, figure 6) :

Drmpt South of Langworthy, Iowa.

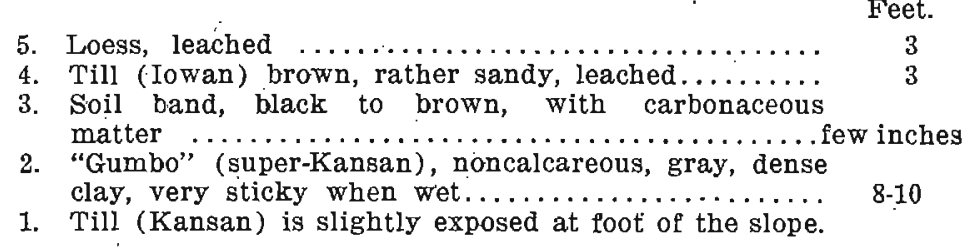

Across the sag to the south ( $\mathrm{B}$, figure 6 ) similar relations are shown at the same level. The cut and boring here showed:

Drtgit South of Langwortery, Iowa:

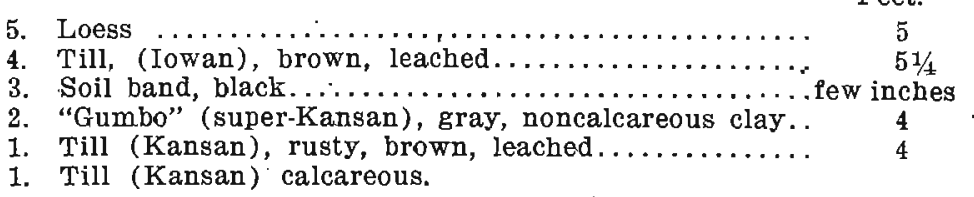

The "gumbo" is like that overlying the Kansan drift in southern Iowa and is believed to mark the same horizon.

Neighboring wells show this ridge to be wholly of drift and to overlie an old valley cut in the rock. Numerous wells have penetrated 200 to 400 feet or more of drift and underlying sand and gravel. It is quite possible that this includes both Kansan and pre-Kansan, besides Iowan, deposits. Farther southeast the ridge is much dissected and numerous cuts show the highly oxidized upper part of the Kansan till but with no overlying later till. The loess-mantled ridge is eut by sharp ravines where crossed by the Anamosa-Monticello road, on which are the exposures described above, but farther northwest the surface becomes smoother and less dissected. These relations indicate that the ridge of Kansan drift was overridden by the Iowan ice as far southeast as this road but not much if any farther. The buried soil and "gumbo" thus mark the horizon of the original Kansan plain which is here nearly 1,000 feet above sea level. 
DELAWARE COUNTY.

In the southwestern part of Delaware county where the mantled topography is very well developed there is a belt of thick drift and here the super-Kansan "gumbo" and soil are found beneath the Iowan till. The "gumbo" was found by Mr. Leighton, exposed about five miles northeast of Ryan (Milo township, Township 88 North, Range 5 West, section 34, west line of southwest quarter) in a road cut in a small hill on top of the ridge at $1060 \pm$ feet above sea level. The cut, together with a boring, showed the following:

DrIFT NORTHEAST OF RYan, IOWA.

Feet.

5. Soil, pebbly $\ldots \ldots \ldots \ldots \ldots \ldots \ldots \ldots \ldots \ldots \ldots \ldots \ldots \ldots$

4. 'Till (Iowan), bright yellow, calcareous nearly to top.....

3. Silt, gray to drab, slightly calcareous.............. 3

2. "Gumbo" (super-Kansan), drab to ashen-gray silt, contains considerable grit and some pebbles, noncalcareous.......4

1. Till (Kansan), reddish brown at top with clay ironstones and ferruginous streaks, leached five feet, calcareous be-

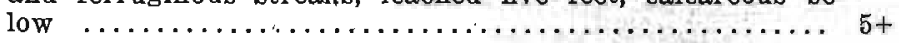

This hillook is one of a group having somewhat the appearance of a moraine.

In a boring on the ridge crest on the opposite side of Lime creek valley at a point about two miles southeast of Ryan (Hazel Green township, Township 87 North, Range 5 West, seotion 29, north line of northwest quarter) the following similar series of beds were penetrated:

Drift Southeast of Rran, Iowa.

Feet.

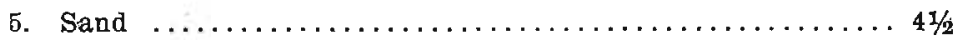

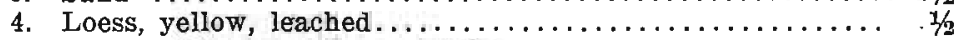

3. Till (Iowan), yellow, leached.................. 1

2. Silt, very dark gray, loesslike in texture, noncalcareous.... 11/2

1. "Gumbo"-like clay (super-Kansan), gray, mottled brownish, containing quartz pebbles and samse decomposed greenstones and granite pebbles, penetrated.............. $1 / 2$

This is on the highest part of the broad ridge at $1080 \pm$ feet above sea level, in a district where wells show 160 feet of drift.

Later, in company with R. D. Salisbury, Frank Leverett, and G. F. Kay Mr. Alden observed several exposures (at 1040 \pm feet above sea level) in cuts on the north-south road between sections 28 and 29,32 and 33 , showing: 
DrfFT SOUTheast of Ryan, Iowa.

3. Till (Iowan), leached, a few feet.

2. Soil, black, carbonaceous, a few inches.

1. "Gumbo" (super-Kansan?), dense,. gray, noncalcareous clay containing small pebibles; exposed for a few feet.

BUCHANAN COUNTY.

On going northwest along the same belt of relatively high country and thick drift some exposures were found in eastern Buchanan county.

About four miles southwest of Masonville (Middlefield township, Township 88 North, Range 7 West, section 3, west line) the north-south road crosses the crest of a high ridge, the continuation of the belt of thick drift seen farther southeast. The crest stands 1,100 feet above sea level. Wells on this ridge are said to penetrate 200 to 265 feet of drift so that it appears that a valley cut in the rock underlies the ridge. A cut and boring on the crest of the ridge showed:

Drift SOUTHWest of Masonville, Iowa.

Feet.

Soil, black, sandy, pebbly loam..................

Till (Iowan), brownish yellow, leached four feet and calcareous

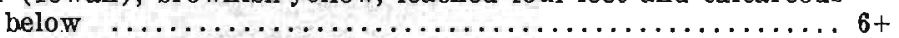

At a point fifty to sixty feet below the top of the south slope a bed of "gumbo" was slightly exposed in the ditch (at 1050土 feet above sea level) beneath a thin covering of till. The ditch and boring showed:

Drift Southwest of Masonvmle, Iowa.

Feet.

Loam, black, pebbly................... 11/2

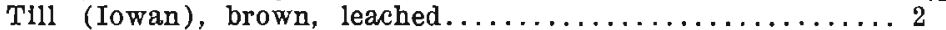

"Gumbo". (super-Kansan) dense, sticky, gray, noncalcareous. . 3+

If one may judge from the relations noted elsewhere the "gumbo" probably extends back horizontally into the ridge so that there may be fifty feet of Iowan till above it. The underlying till is not exposed but the wells of the region indicate that there is probably a considerable thickness below the horizon of the "gumbo."

About six miles north of this place (Fremont township, Township 89 North, Range 7 West, section 11, west line of northwest quarter) in the same high belt of thick drift, a boring on the slope 
of the ridge about fifty feet below the top (at 1,090-1,100 feet above tide) showed:

DRIFT NoRTHWEST OY Masonville, Iowa.

Feet.

Till (Iowan), brown, leached and very stony.......... 11/2

"Gumbo" (super-Kansan), dense, gray, noncalcareous clay 4

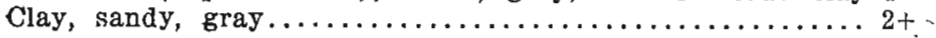

A boring on the crest of the ridge a mile farther north at.1,140 feet above sea level showed:

Drift Nerthwesx of MasontmLe, lowa.

F'eet.

Soil, black ...........................

Till (Iowan), yellow, leached..................

Till, calcareous below ........................ $51 / 2+$

Here again it appears there may be a considerable thickness of Iowan drift above the horizon of the "gumbo" in the body of the ridge though it is very thin at the point of outcrop in the slope.

A cut on the Chicago, Anamosa and Northern railway one mile east of Kiene in Middlefield township, Township 88 North, Range 7 West, section 34, southwest quarter, exposed the following:

Drift on Chicago, anamosa \& Northern Rathway East ot Krent, Iowa.

Feet.

6: Humus. dark, and brown pebbleless clay..........11/2

5. Line of pebbles.

4. Till, buff to brown, leached, clayey.............. 4-6

3. Till, similar to above, but calcareous, with abundant iimestone pebbles ......................... 2

- Distinct line of division, not a gradation zone.

2. Clay, dense, dark slate colored, ashen gray in places and oxidized brawn along joints and bedding or cleavage planes. Suggests the super-Kansan "gumbo".......... 5

1. This grades down into dark, slate-colored, pebbly clay till, brown in places, noncalcareous.

The lower till No. 1, resembles the unoxidized Kansan except in being noncalcareous where tested. The upper till, Nos. 3 and 4, above the distinct division line, is like that generally present at the surface in the Iowan area.

\section{LLNN ROUNTY.}

In Linn county about four miles northeast of Center Point (Otter Creek township, Township 85 North, Range 7 West, section 4, south line) a boring made in a shallow road cut oil the gently undulating plain showed the following: 
Till (Iowan), leached ..........................

Clay, yellowish gray, gritty and noncalcareous and of texture suggesting super-Kansan "gumbo" .............. 3

Three miles northwest of Central City (Jackson township, Township 86 North, Range 6 West, section 21, north of center) "gumbo" is exposed beneath till in a road cut near the top of the east slope of the hill. The road cut and test bores made in the bottom of the cut show the following beds:

Drift Northwest of Central City, Iowa.

Feet.

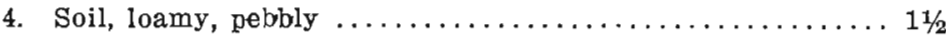

3. Till (Iowan), brownish yellow, leached............. 21/

3. Till (Iowan), calcareous, yellow, grading downward into

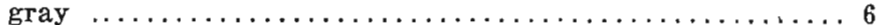

2. "Gumbo" (super-Kansan), noncalcareous, black soil with wood at top, dark gray below, with "buckshot" texture and rare small pebbles of chert and quartz (one dolerite found)

1. Sand and gravel.

This exposure is about twenty-five feet below the top of the ridge and about 120 feet above Wapsipinicon river, one mile distant. The relations here and at the following exposures suggest that a thin bed of Kansan till underlain by sand or sand and gravel has been wholly changed to "gumbo."

In the southwestern part of the county four miles east of Atkins (Linn county, Clinton township, Township 8:3 Nortts, Range 8 West, section 16, southwest quarter) a cut on the Chicago, Milwaukee \& St. Paul railway through the southeast end of a paha shows the following:

\section{DrTPT EAst of ATKINS, Iowa.}

Feet.

5. Loess, buff, calcareous in lower part ..............15

4. Till (?) (Iowan?), reddish to yellow leached pebbly clay.0-1

3. "Gumbo" (?), soft, dull brownish to reddish gray clay, noncalcareous and with some small pebbles and sand

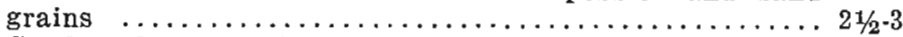

2. Sand and gravel, buff $\ldots \ldots \ldots \ldots \ldots \ldots \ldots \ldots \ldots$

1. Till (Kansan?), leached, with rotten pebbles and bowlders 1

1. Till (Kansan?), gray, calcareous ..................

BENTON GOUNTY.

Three or four miles southeast of Brandon (Harrison township, Township 86 North, Range 10 West, section 12, northwest quar- 
ter) the deeper part of a cut on the electric railroad, on top of the ridge (at $900 \pm$ feet above sea level) showed the following:

Dritit Southeast of Brandon, Iowa.

Feet.

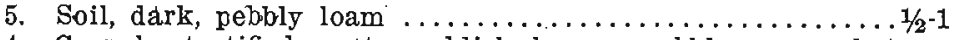

4. Gravel, stratified, rusty reddish brown, pebbles somewhat decayed, clay ironstone present, noncalcareous.......... $0-4$

3. Sand and gravel, brown, cross-bedded, noncalcareous..... 3-4

2. "Gumbo", dense, sticky, gray, noncalcareous, pebbleless clay 3

1. Grading down, in one part, into gray clayey sand to loose sand. In the lower part a bright yellow streak and below this the nearly white sand, total exposed.............6

The "gumbo"' (No. 2) resembles the super-Kansan "gumbo" of southern Iowa, but it is overlain by sand and gravel and grades down into loose sand.

Two miles north of Newhall (Eldorado township, Township

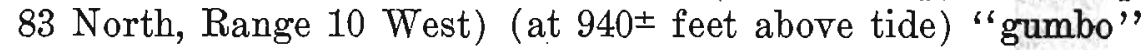
was observed in cuts on the road north and west of the southeast corner of section 1 about ten feet below the top of the slopes. Cuts and borings gave the following section:

DRIFT North of Newhill, Iowa.

Feet.

3. Till (Iowan), yellow, leached $\ldots \ldots \ldots \ldots \ldots \ldots \ldots \ldots$

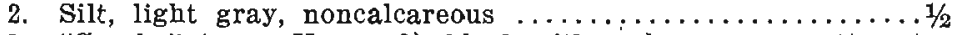

1. "Gumbo" (super-Kansan?), black with carbonaceous matter at top, dark gray below, dense rubber-like clay, noncalcareous, exposed $\ldots \ldots \ldots \ldots \ldots \ldots \ldots \ldots \ldots \ldots \ldots \ldots \ldots$ few feet

This is on one of the highest tracts in this part of the country. The "gumbo" is cut off by the slope, apparently having been eroded prior to the deposition of the upper till which now mantles the slope and covers the "gumbo."

Three miles south of Vinton (Eden township, Township 84 North, Range 10 West, section 3) a boring on the ridge just south of the northwest corner penetrated the following:

DrHFT South of VInToN, IOWA.

Feet.

4. Loess, brownish yellow, leached $\ldots \ldots \ldots \ldots \ldots \ldots \ldots \ldots . \ldots . \ldots$.

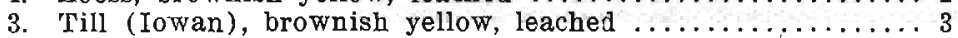

2. "Gumbo"-like clay (super-Kanson), dark gray, leached..... 1

1. Till (Kansan), brownish yellow, leached; penetrated....... 2

BLACK HAWK COUNTY:

In the southwestern part of Black Hawk county the following was found in the Chicago \& North Western railway cut one-half mile northwest of Voorhies. Part of the section was determined 
by boring at two different levels, the lower hole reaching a depth of five and one-half feet bielow the track.

Drtat NomThwest of VookHIEs, Iowa.

Feet.

7. Clay, loesslike

$31 / 2$

6. Till (Iowan), buff, leached, clayey $\ldots \ldots \ldots \ldots \ldots \ldots \ldots 3-31 / 2$

5. Till (Towan), buff, calcareous ................ $11 / 2$

4. Clay, dense bluish gray, noncalcareous, containing small quartz pebbles; "gumbo" (?) .................. $3-31 / 2$

3. Clay (Kansan till), brown to gray, leached, pebbly..... 俈

2. Clay, brownish gray, mostly leached but calcareous in spots or with small limestone pebbles, crystalline pebbles rotten (Kansan till) $\ldots \ldots \ldots \ldots \ldots \ldots \ldots \ldots \ldots \ldots \ldots \ldots 7$

1. Till (Kansan), dense, buff, calcareous ............. $51 / 2$

While the part of this section determined by the two borings maÿ not be exactly continuous, it seems probable that Nos. 5 and 6 comprise the Iowan till. Number 4 is like the super-Kansan "gumbo," and Nos. 1, 2, and 3 are probably Kansan till, including the gradation zone.

This cut was examined by. Prof. M. F. Arey and described somewhat differently in his report ${ }^{9}$. At the time of the writers' visit in 1914 the section was obscured by vegetation.

\section{FAYETTE COUNTY.}

To the northwest, in Fayette county, one of the best exposures was found five miles west of West Union (Windsor township, Township 94 North, Range 9 West, section 16, north line of the northeast quarter), in a road cut through a small ridge or lobe of the slope at $1200^{ \pm}$feet above sea level. The cut and boring showed the following:

DRART WRST OF WEST UNION, IOWA.

Feet. Inches.

5. Till (Iowan), yellow, calcareous in lower part.. 10

4. Clay, loesslike, gray above, rusty brown in lower

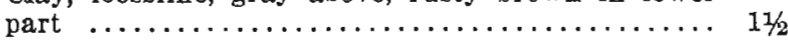

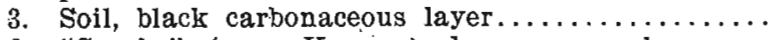

2. "Gumbo" (super-Kansan) dense, gray clay, noncalcareous ......................... $5 \pm$

1. Till (Kansan), rusty brown, leached......... $31 / 2$

1. Till (Kansan), calcareous.

The soil and "gumbo" were exposed at both ends of the cut, but were below the level of the road in the middle of the cut. A boring through No. 4 in the bottom of the middle of the cut showed that the soil (No. 3) and "gumbo" (No. 2) really extend 
through the ridge. A boring in the bottom of the ten-foot cut on the east line of the northeast quarter of the same section showed the black soil No. 3 and "gumbo" No. 2 to be'present there also.

Two miles south, on the west line of the northwest quarter of section 27 (at 1220 feet above sea level) a boring with the anger penetrated the following:

DRMT EAST OF HAWREYE, IOWA.

Feet.

4. Soil, dark, pebbly.

3. Till (Iowan), yellow, sandy, leached............ 3

2. Soil, dark, carbonaceous band.

1. "Gumbo" (super-Kansan), dense, tough, rubber-like gray

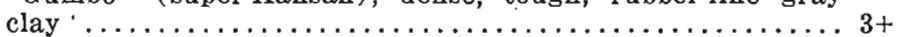

These occurrences of the buried soil and "gumbo" are in the higher parts of the gently undulating upland plain at $1140 \pm$ feet above sea level.

\title{
HOWARD COUNTY.
}

Still farther north near the eastern border of the Iowan area in Howard county, an exposure in the new pit at the brick yard just north of the railroad, together with a boring made in the bottom, showed:

DrLFT ax CBesco.

\author{
Feet.
}

3. Soil, pebbly . . . . . . . . . . . . . . . . .

2. Till (Iowan), brownish to yellow, sandy, leached, with crystalline pebbles and bowlders up to two foet in

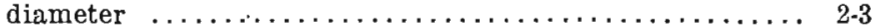

1. Clay, "gumbo"-like, (super-Kansan), noncalcareous, "buckshot" texture in places, upper lew inches to one foot light drab, darker drab two to four feet (as though colored by carbonaceous material), light greenish drab, then mottled brownish yellow to drab below......... $7+$

In this connection the following description of exposures at Cresco from the notes of R. T. Chamberlin, made July 18, 1907, is of interest. This shows the presence of calcareous till (Kansan) below the gummy clay.

Cresco brick yard.- South pit, this is the deepest pit but is not used at present. At northwest end of this pit the bank shows three and one-half feet of yellow brown Iowan drift noncalcareous throughout. The upper portion merges into the surface dirt. I failed to find a single limestone pebble in it even after a careful search. There are frequent cherts and a good many quartzites and the tiny pebbles of gray or white granite and other 
light-colored igneous rocks which are so characteristic of the Iow.an. Below the Iowan is a nondescript gummy clay mixed with some sandy layers which looks very much like interglacial material. The gummy clay contains many of the polished quartz pebbles and may have been washed in from a gummy portion of the older drifts during the Buchanan period. It is noncalcareous.

I looked over the bank of Iowan very carefully, noting carefully several hundred pebbles-in fact all that could be seen in some twenty feet of bank, collecting all the suspicious cherts that might possibly prove to be still calcareous but though I split open and tested with acid fifty or more of these (chiefly cherts for I could spot the igneous rocks readily) there was not a single pebble that effervesced to the slightest degree.

The bottom of the brickyard is strewn with numerous large bowlders of the Iowan type, doubtless encountered in and left behind when that drift was removed. At the lowest point in the pit a prospect hole has been dug some feet deeper (how much is not apparent since it is filled with water and is now a small pond). The material taken out has been piled nearby. It is found to contain abundant limestone pebbles, but this comes from below the gummy stuff and the layer of sand and is neither the Iowan nor the olay used for the brick. It is probably Kansan drift. The foreman volunteered the information that the clay which they used contained no lime but that they got in their prospect lower down contained limestone pebbles and hence was not desirable.

In the west pit the Iowan drift is only about $2 \mathrm{ft}$. thick. Then comes a horizon of bluish-grayish brown gummy clay with lenses and patches of gray sand. The thickness of this is about 3 feet to the floor of the pit. The floor of the pit is a layer of grayish sand which is not desirable and avoided. Below this as shown in the other pit is another drift containing limestone pebbles.

\section{MITCHELL COUNTY.}

About eight miles west of Osage (Rock township, Township 98 North, Range 18 West, section 34, middle of west line) a boring on a low slope penetrated mottled gray and yellow, dense, sticky clay with few pebbles. This clay suggests the superKansan "gumbo" rather than the normal weathered till. Five feet down this becomes sandy and wet.

A few miles to the north in section 11 (south line of the southeast quarter), a boring on the extensive flat plain showed: 
2. Clay humus, black....................... 11/2-2

1. "Gumbo," dense, sticky, gray, noncalcareous clay containing fow small pebbles..................... 8

Near the underlying limestone the clay is yellowish in color.

A cut on a short steep slope a short distance east of this, and about three miles west of Mitchell, together with a boring, penetrated nine feet of "gumbo," dense, tough, rubber-like, brownish, noncalcareous clay. There is no overlying till (Iowan) at these places but drift pebbles and bowlders scattered over the surface show that the "gumbo" has been overridden by later ice.

One mile north of Mitchell (Mitchell township, Township 98 North, Range 17 West, section 5, west line of the southeast quarter), a boring on the flat upland plain (at $1190 \pm$ feet above sea level) penetrated, beneath two feet of dark loesslike loam, the same dark brown to gray, dense, noncalcareous "gumbo" clay, rusty in spots, to a depth of nine feet. There is here no overlying till, only drift pebbles and scattered bowlders one to three feet in diameter. Two miles east of Mitchell (section 11, west line of the southwest quarter) the same dense brown clay, with "buckshot" of $\mathrm{MnO}_{2}$, was found by boring beneath five and one-half feet of loess and one and one-half feet of sand.

At another place about five miles northeast of Mitchell (near the northeast corner of section 1) a boring on the flat plain revealed:

$$
\text { Draft Northeast of Mrtcherl, Iowa. }
$$

3. Humus, black clay .................................

2. 'Clay, gray, loesslike, no pebbles excepting at bottom...... 1

1. "Gumbo," dense, brownish gray, noncalcareous clay, sandy

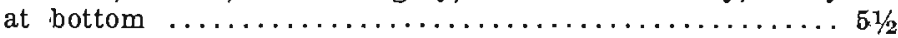

Again, a boring one and one-h́alf miles east of St. Ansgar (at $1170 \pm$ feet above sea level) showed:

DrmT EASt of St. ANsgar, Iowa.

3. Soil, black, and loess.......................

2. Clay, sandy, brown, with some pebbles (possibly Iowan

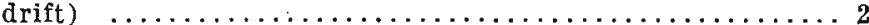

1. "Gumbo," dense, sticky, gray to brown, noncalcareous clay with scattered small chert pebbles and sand grains...... 41/2 
This becomes light buff in color at the bottom near the underlying limestone. There appears to be but little glacial drift of any kind at these places. The nearly flat plain may be part of the original Kansan upland, which escaped erosion and on which the conditions for "gumbo" development existed.

WORTH COUNTY.

In borings at two points in the southeastern part of Worth county on the plain east of Manly, there was penetrated very dense, brownish to gray clay, noncalcareous, and containing few small pebbles. This suggests the "gumbo"-like clay found farther east in Mitchell county, and may really be the long weathered upper part of the Kansan till with no overlying Iowan drift. 'A short distance from one of these places, that is, in the low slope just east of Manly, fresh-looking till containing limestone and other pebbles was thrown out in digging a ditch. This may be the Iowan.

CERRO GORDO COUNTY.

In the western part of the Iowan area, at several places on the gently undulating, little-dissected plains of Cerro Gordo county, the auger penetrated very dense, noncaleareous clay, in most cases gray or drab colored, in some cases brownish. This clay contains few or no pebbles and suggests the super-Kansan "gumbo." It is unlike the ordinary weathered upper part of the Kansan till or of the Iowan till. In places this grades down into clay which is of similar color and texture but is calcareous and contains limestone and other pebbles, which indicates that it is till. It might be that the character of the clay here is due to the incorporation of much material from the underlying Lime Creek shale.

\section{FRANKLIN COUNTY.}

Several miles southeast of Hampton there is a loess-mantled, bulky ridge between Squaw and Haynes creeks. This may be a remnant of an old divide on the Kansan drift plain. A cut and boring near the crest of the ridge (Geneva township, Township 91 North, Range 19 West, section 7, northwest quarter) (at 1200 feet above sea level) showed: 
DRIFT Southegast of Hampton, Iowa.

Feet.

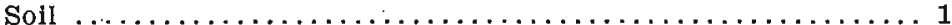

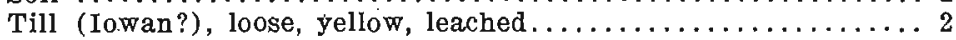

Clay, "gumbo"-like, lense, dark brown, sticky, noncalcareous and with coarse sand grains or small pebbles in lower part......6

Dark browh sandy material (decayed limestone?)........... 1

Limestone.

Two miles southwest of Faulkner (Osceola township, Township 90 North, Range 19 West, near southwest corner of section 17) three feet of dense, gray, noncalcareous "gumbo" is exposed in the slope beside the schoolhouse (1140 \pm feet above sea level) below thin pebbly till. This is near the foot of the slope which marks the margin of the Wisconsin drift. It is thus impossible to say whether the thin pebbly till above the "gumbo" is Iowan or Wisconsin.

TAMA COUNTY.

There are several exposures of "gumbo" in Tama county, but the interpretation to be placed upon them is, at present, somewliat problematical. The exposures are in tracts where much dissection has occurred so that it is possible the overlying till, where such is present, may be Kansan instead of Iowan till. At one exposure there is no overlying till and the "gumbo" may be regarded as super-Kansan.

About four miles northwest of Toledo, near the middle of the east half of section 7 (Township 83 North, Range 15 West), gray, noncalcareous "gumbo," spotted with red at the top, outcrops beneath the loess, in the west-facing slope, about twentyfive feet below the top. Beneath is leached, brown till (Kansan?). Between two and three miles northeast of Gladstone (Otter Creek township, Township 83 North, Range 14 West, line section 22) the Chicago, Milwaukee \& St. Paul railway cut just east of the viaducts affords an interesting exposure of the following deposits (figure 7):

Druip NoRtheast of Gladstone, Iowa.

4. Loess, buff, leached for four feet, gray in lower part where thickest and contains $\mathrm{CaCO}_{3}$ concretions............. 5:10

3. Upper till, oxidized brownish in upper part and with distinct pebble band at top, leached for three feet, highly calcareous below, with $\mathrm{CaOO}_{3}$ concretions.............. 3-6 
2. Clay, "gumbo," dense, gray, noncalcareous and containing scattered small pebbles. Upper surface uneven as though eroded or disturbed by the overriding ice............ 6

1. Lower till, oxidized brownish for ten feet \pm , highly calcareous to base of "gumbo." This grades downward into gray to dark slate-colored till full of $\mathrm{CaCO}_{3}$ concretions;

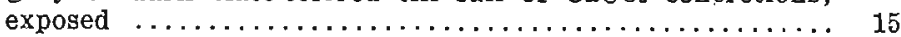

$\Xi$.

W.

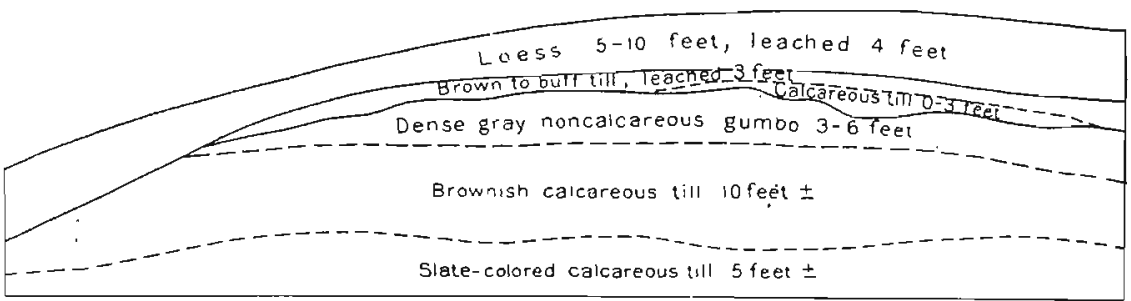

Fig. 7.-Diagram of drift exposed in Chicago, Milwaukee \& St. Paul railway cut northeast of Gladstone, Iowa.

There is gradation between No. 1 and No. 2. Numbers 2 and 3 were cut away at both sides by erosion prior to the deposition of the loess. The latter mantles the crest and slopes of this spur of the upland. Estimates of pebbles from the upper and the lower tills show no marked difference in lithology.

About a mile northeast of this place (in Otter Creek township, section 11, near the southeast corner) dense, dark gray gumbo, mottled with red in the upper part, was seen exposed beneath five to ten feet of loess and still farther northeast a road cut just south of the middle of section 1 exposed the following:

Drift Northwest of VINING, Iowa.

Feet.

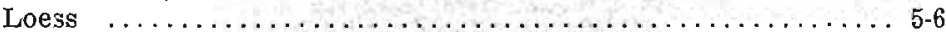

"Gumbo," dense, brownish gray, tough and noncalcareous..... 5

Till (Kansan?), brown, leached, exposed in slope........... 7

Between four and five miles north of the railroad cut and about three miles northwest of the exposure last noted. above (in a slope one-fourth mile south of the schoolhouse on the east line of section 33, Carroll township, Township 84 North, Range 14 West) gray gumbo was exposed twenty-five to thirty feet above the bottom of the till slope. This has a thickness of at least five feet, as was determined by boring; it appears to grade into the till below and is overlain by thin brownish till. At levels six and ten feet higher up the gumbo is slightly exposed in patches 
surrounded by till as though it outerops through holes in an overlapping thin mantle of till.

Some of the other cuts in Carroll and Otter Creek townships show a distinct reddish brown ferretto at the top of the till and beneath the loess. At these places and at those where the top of the till is less highly oxidized, the "gumbo" and upper till are not seen, evidently because of their removal prior to the deposition of the loess. These exposures in Tama county are in a belt of country five to twelve miles wide which lies north of Iowa river valley and west of Salt creek valley, and in which a notable amount of erosion was accomplished prior to the deposition of the loess. Most of this area has been mapped as outside the limit of the Iowan drift and there is good reason for regarding it as such. The presence, however, of an upper till overlying the gumbo in the exposures in Otter Creek and southern Carroll townships raises the question whether the Iowan ice may not have extended as far south as Iowa river valley. Is the succession to be regarded as:

Loess

Till (Iowan)

"Gumbo"

Till (Kansan)

or, as in Carroll county:

Loess

Till (Kansan)

"Gumbo"

Till (pre-Kansan)

The same question is raised by conditions observed about twelve miles farther north. Seven or eight miles west of Traer (Grant township, Township 86 North, Range 15 West, section 33 , near middle of south line) a road cut on the steep slope of a ravine tributary to' Four-Mile creek exposed the following, when seen in September, 1915:

DRIFT WEST OF TRAER, IOWA.

6. Loess, buff to grayish....................... 20

5. Till, rusty brown and very stony at top........... $5-10$

4. "Gumbo," dense, sticky, gray, noncalcareous clay..........4 
3. Till, gray, crumbly and full of arkosic material as from

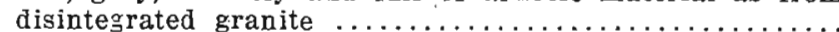

2. Till, brown, leached........................... 4

1. Till, brown, highly calcareous.

There is gradation from No. 1 to No. 2, from No. 2 to No. 3 and from No. 3 to No.4. A boring sunk through the lower four feet of No. 5 into No. 4 showed that the "gumbo" really extends back into the hill beneath the upper till. Between two and three miles farther east on the north side of Wolf creek valley there is, beneath ten feet of loess, a dark ferretto at the top of the leached till. A little lower down the valley gumbo is exposed but.it appears not to extend into the hill. At one place the gumbo itself is red. Unfortunately there was insufficient time, when this exposure was found, to determine what were the real relations, as they were not clearly shown in the cut.

The country bordering Wolf and Four-Mile creeks west of Traer has a maturely dissected topography with seventy to one hundred feet of relief, in contrast with the little-eroded, gently undulating topography immediately to the north and south, so that there is the same question as to whether the succession is:

\section{Loess}

Till (Iowan)

"Gúmbo"

Till (Kansan)

or :

\section{Loess}

Till (Kansan)

"Gumbo"

Till (pre-Kansan)

The question concerning the interpretation of the age of the deposits in these Tama county exposures arises from the fact of their occurring in tracts where the amount of erosion which has been accomplished since the deposition of the upper till is considerably more than that generally seen in the Iowan area and about the same as that in the Kansan area south of Iowa river. Further, in several new cuts along the line of the Chicago, Milwaukee \& St. 'Paul Railway west of the area of the Des Moines lobe in southern Carroll county and southeastern Craw. 
ford county, a well developed bed of similar dense, gray, noncalcareous "gumbo" lies between two highly calcareous' till sheets. Here the general relations and the large amount of erosion which has been accomplished since the deposition of the upper till indicate that the latter is of Kansan age. If this be correct, there is clearly a pre-Kansan (or super-Nebraskan) "gumbo" as well as a super-Kansan "gumbo." As indicated above, the relations are much the same in Tama county, so that, for the present at least, final judgment as to these latter exposures must be suspended.

The question may be asked, "If there is evidence of a preKansan bed of "gumbo" why may not the "gumbo" at all the exposures cited above be of pre-Kansan age and the overlying till in the Iowan area be Kansan?" In answer to this it may be said that the wide distribution of "gumbo" on top of the Kansan drift in southern Iowa and its general absence from the surface of the uppermost till in the Iowan area, excepting near Mitchell, makes it much more probable that the upper till in the Iowan area is post-Kansan and that the underlying "gumbo" is super-Kansan. Then too the moderate amount of modification by weathering and the small amount of erosion of the uppermost till of the Iowan area, taken as a whole, seems. to the writers evidence that the latter till is younger than Kansan. The different lines of evidence, support each other.

While it may be necessary to withhold judgment concerning some of the occurrences cited above, it seems to the writers that there remains a body of definite evidence indicating that there really is a distinct super-Kansan "gumbo" and a post-Kansan drift in the Iowan area.

Day. G. F., Pleistocene deposits between Manilla in Crawford County and Coon Rapids in Carroll County: Iowa Geological Survey, Vol. XXVI, pp. 213-231. 


\section{CHAPTER IV}

\section{OTHER EVIDENCES OF POST-KANSAN GLACIATION. \\ General Character}

Besides the lines of evidence which already have been presented and those which are to follow, certain phenomena have been noted which, though susceptible of various interpretations and not conclusive in themselves, are, in a way, corroborative and lend support to the foregoing conclusion. These include descriptions of some exposures of Iowan drift and logs of wells taken from the reports of the Iowa Geological Survey and from W J McGee's paper on northeastern Iowa, which may be presented together in this chapter.

In the course of the present investigation an effort was made to examine most of the exposures to which definite reference had been made in the published papers as showing Iowan till distinguishable from older deposits. Some of the old exposures are now so badly slumped and overgrown that no accurate determination of the deposits can be made. Most of those seen were unsatisfactory. Some of the old exposures and some of the new ones are suggestive. Taken by themselves most of them are of very slight value as evidence of post-Kansan glaciation. A few, such as the cut in Johnson county, are important. They embrace occurrences of till over silt or loess; of two tills with. an intervening soil; till over weathered gravel; till over more weathered till; till with apparent intermixture of older "gumbo" or other deposits.

For readiness of reference, these are presented somewhat in detail in the form of notes.

Notes on certain other supposed occurrences of Iowan drift may be found in Appendix $\mathrm{C}$.

WINNESHIEK COUNTY:

A boring at a point about five miles southwest of Ridgeway (in Sumner township, Township 88 North, Range 10 West, section 4, west line of the northwest quarter), showed the following: 
DRTFT SOUTHWEST OF RDGEWAY, IOWA.

Feet.

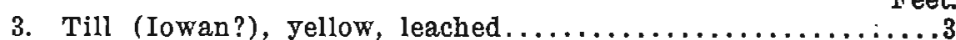

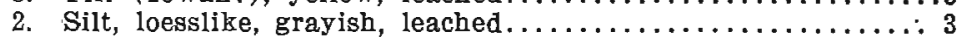

1. Till (Kansan?), leached for one foot, calcareous below.

HOWARD COUNTY.

Professor Calvin ${ }^{10}$ described the section exposed in a cut on the Chicago Great Western railway south of Elma, as follows:

A deep railway cut one and a half miles south of Elma reveals the Kansan drift in its unweathered phase. A few rods north of a wagon bridge which here spans the cut, the section shows:

3. Yellow, unweathered Iowan till................ 6

2. Old peaty soil developed in the intervals between the Kansan

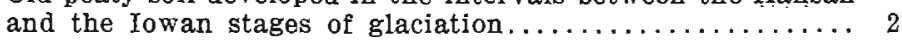

1. Blue unweathered Kansan to bottom of the cut........... 15

There is here no ferretto zone at the surface of the Kansan; the organic material of the peaty soil bed was capable of more than counter-balancing any effects of oxidation which might have taken place before the Kansan surface was covered and protected from further change by the deposition of the Iowan drift.

\section{CHICKASAW COUNTY.}

In July, 1907, R. T. Chamberlin examined the cuts southeast of New Hampton on the Chicago Great Western railway. At the gravel pit one-fourth mile southeast of the station, overlying ten feet of rusty red-brown sand and gravel at the south end of the exposure, he found "'nearly two feet of a yellowbrown, non-calcareous drift, presumably Iowan, since there are Iowan bowlders on the surface of the hillside." The following also is from his notes:

Half a mile from the station at the overhead bridge is a cut nearly 20 feet deep where the steam shovel has been within a year or two. This cut is through a ridge so that the level of the tracks is slightly higher than the top of the gravel in the pits just mentioned (Top of both gravels appear same height). The section here is :

Iowan drift

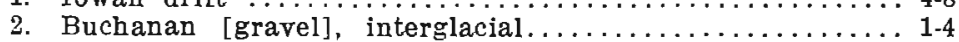

3. Kansan, brown above, but chiefly bluish till............6.6

4. Aftonian sands and gravels, upper eight inches cemented with $\mathrm{CaCO}_{3}$. Below this non-consolidated and easily dug. Upper part at about the level of the tracks. Thlckness exposed by digging a little into the talus...............

${ }^{10} I$ owa Geological -Survey, Vol. XIII, p. 63. 
The bottom of the ditch is here several feet below the level of the tracks. The Iowan is here noncalcareous, yellow brown, and stands well as a cliff face. The Buchanan is very variable. In some places there is a distinct soil line at its top. Throughout most of the cut it contains layers of clean yellow sand and generally free from pebbles. In some places this is very soft; elsewhere it has been cemented into a true sand stone. Interbedded in some places are clayey layers. Where the Kansan and Aftonian are best exposed the Buchanan loses its chief characteristics, being represented here by altered streaky sandy and clayey till.

The upper portion of the Kansan becomes brownish but the greater part is bluish. It is calcareous throughout. The Aftonian resembles that at Afton Junction closely.

See tables (Appendix A) for estimates of pebbles from these various deposits.

The cuts were examined in 1914 by the present writers. At the gravel pit Mr. Leighton found:

$$
\text { DBIFT SoUtheast of NeW Hamptor, Iowa. }
$$

Feet.

Clay, yellow, with occasional pebbles............... 2

Gravel and sand, yellowish brown to reddish brown, cross. bedded, leached of all calcareous material, granites, greenstone and dolerites much decomposed. Clay ironstones present 20

The railroad cut at the viaduct was too badly obscured by vegetation and slumping for accurate determination except in the upper part.

\section{BUCHANAN COUNTY.}

An exposure frequently mentioned in connection with discussions of the Iowan drift is the old gravel pit near Doris on the Illinois Central railroad, about four miles east of Independence (Byron township, Township 89 North, Range 8 West, section 32 , northwest quarter). This was Doctor Calvin's type exposure of Buchanan gravel, if not also of Iowan till. The exposure is almost wholly obscured by slumping and vegetation. Trees up to eight inches in diameter have grown in the bottom of the excavation and the banks are mostly grassed.' On the north side, when the pit was visited by the present writers in 1914, there had been some recent excavation for road gravel so that the upper till and the underlying gravel were well exposed through 
a space about fifty yards in extent. The following" was seen below the level of the gently undulating bowlder-strewn Iowan plain:

Ditift at Ilinnols Central Rallood Gravet Pit, Doris, Iowa.

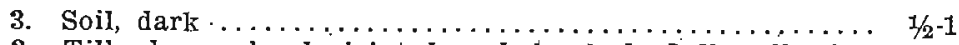

2. Till, dense, hard, jointed and leached, dull -yellowish,

pebbly. No limestone pebbles seen............... 3

1. Gravel, rusty brown, ferruginous, pebbles small to eight inches in diameter, largely of polished quartz and chert

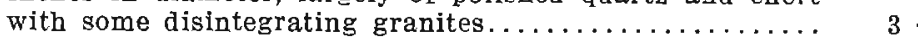

In two places stringers of gravel run up into the till and in one place the till extends down one and one-half feet into a depression in the gravel. The deposit overlying the gravel is clearly glacial till and the only question is that of its age. The gravel as originally exposed is reported to extend down to a depth of twenty feet below the base of the upper till and to be underlain by dense bluish till.

In September, 1907, this pit was visited by T. C. and R. T. Chamberlin. The following is from the notes of the latter:

From Independence we drove east to see the famous cut along the I. C. R. R. tracks three miles east of the town. This is the type locality for the Iowan drift. On the way out there we saw sloughs and slight hummocky bunches which cause a slight unevenness in the regular slopes. The topography looks youngalmost Wisconsin in places.

The cut is just west of Doris station and has been used extensively for gravel. The pit shows Buchanan gravels capped by 0-6 feet of a fresher appearing yellowish till which closely resembles the upper yellow till at Oelwein. It is a brighter colored material than is usual in the oxidized part of the Kansan, but it contains more $\mathrm{Fe}_{2} \mathrm{O}_{3}$ apparently for the shades are deeper than the yellow gray Kansan upper zone. The upper part is non-calcareous as is the till at Oelwein, but the lower portion is calcareous. Leaching has gone down about 4 feet.

Below this till are the Buchanan gravels which is the material sought for the railroad. They are considerably oxidized but contain inclusions of till. Fifty pebbles dug from the Iowan drift at this gravel pit were classified. (See Table No. ITT, Appendix A.)

The striking feature of this set of pebbles is the old and weathered condition of the igneous rocks and the great propor- 
tion of polished quartz and chert pebbles. The granites were crumbly while the greenstones generally were incased in thick weathered zones. The mica schist was very rotten.

The highly polished quartz and chert pebbles were of the type usually assigned to pre-glacial deposits. They may have been subject to wind polishing while resting upon the surface of the older drift, while the Iowan glacier was advancing. However, some of the other quartz pebbles were sub-angular and not polished at all though they might have been buried beneath the surface.

On the whole it looks as though the Iowan ice had merely scraped up the surface portion of the older drift and that these old and weathered pebbles received most of their weathering before incorporated in the Iowan drift.

The idea of the Iowan being "calcareous to the grass roots" is not supported at Independence nor at any other point where I have seen this drift. Its darker color compared with the fresh yellow Kansan may be due to the fact that some of the oxidized ferretto material has been mixed with scrapings of the yellow till. The Buchanan gravels below looked older than the Iowan.

The relations of the Iowan till to the older deposits are illustrated by the following cited by Doctor Calvin ${ }^{11}$ :

A very common relation of Pleistocene deposits is illustrated by the well section on land of J. W. Welch, in the southwest quarter of section 28, Buffalo township. The record shows,

. Feet.

3. Dark soil and yellow till...................... 4

2. Reddish ferruginous sand and gravel............... 23

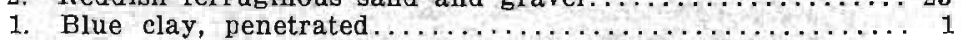

No. 1 of this section is Kansan drift, No. 2 is Buchanan gravel, and No. 3 is Iowan till. In the same quarter section another well shows:

Feet.

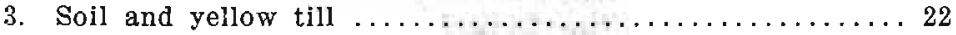

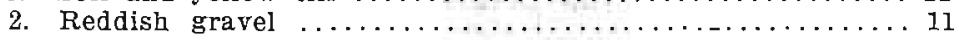

1. Blue clay, with pockets of sand................. 19

Concerning the relations at the Doris gravel pit. Doctor Calvin wrote $^{12}$ :

The gravel rests on typical Kansan blue clay and is overlain by yellow Iowan till which varies from less than a foot in thickness at the western end of the exposure to more than six feet at the extreme eastern end. Two facts are at once apparent; first,

110wa Geological Survey, Vol. VIII, pp. 239-240, 1897.

${ }^{13} \mathrm{Op}$. cit, p. 242. 
the gravel is interglacial in position; second, it is very old as compared with the overlying Iowan till.

\section{LINN COUNTY.}

Cuts along the newly graded line of the Waterloo, Cedar Falls \& Northern electric railway afforded numerous clean exposures of the upper part of the drift. In one of these, northwest of Marion (Monroe township, Township 84 North, Range 8 West, section 4, southwest quarter), there is a suggestion of overriding by a readvance of the ice. There seems to be a mixture of leached and calcareous till. The till (Iowan?) at A (figure 8) is highly calcareous below a leached zone three feet in

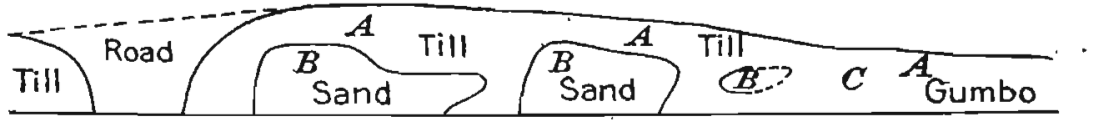

Fig. 8.-Diagram of cut on Waterloo, Cedar Falls \& Northern Electric railway, northwest of Marion, Towa, showing relations of Iowan (?) till to dune sand (B B) and "gumbo" (C) super-Kansan?.

thickness. At B. B. are two pockets of fine sand with dimensions of six by ten feet, which resembles dune sand, and at $\mathrm{C}$ is dense, noncalcareous, gray clay with small pebbles. This resembles the super-Kansan "gumbo.", While the deposits suggest overriding by a readvance of the ice, the relations are not sufficiently clear to make sure that there is more than one till sheet. So also with the next cut in the northwest quarter of section 4 , which shows:

Demit on Waterloo, Cedar Fallas \& Northirk Rantwat, NorthWEST of MaRToN, Iowa.

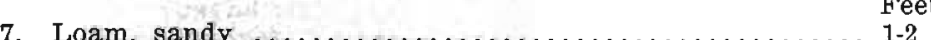

6. Gravel, rusty, in layers and pockets............. $0-2$

5. Till (Iowan?), brown, leached.................

4. Till (Iowan?), brown, calcareous.............. 2-3

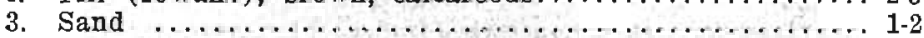

2. Clay, brown to gray, partly leached, partly calcareous... 1-3 This grades down into

1. Clay (Kansan?), dense, dark, slate-colored, pebbly till, In one place below a black strip, possibly a remnant of an old soil, this clay is greenish and calcareous....... 1t

There is more or less mixing and the relations are not so clear and simple as the above might seem to indicate.

And again at the viaduct in Otter Creek township (Township 85 North, Range 7 West, section 29, northeast quarter) is the following: 
Dritt on Waterloo, Cedar Faris \& Norteern Ramway, Six Mores Southeast of. Center Point, Iowa.

Feet.

4. Dune sand, stratified ....................... 5-12

3. Till (Iowan?), light buff, pebbly, leached............ 3

2. Till, similar to above (Iowan?), calcareous............. 1

1. Till (Kansan), dense, brown, calcareous, of different tex-

ture from No. 2 and with a fairly distinct line of division 0. 4

On the washed surface of the lower till (No. 1) are small, brown, pebble-like masses of clay one-fourth to one half inch long which can be crushed with the fingers. They suggest "buckshot" or ferruginous coneretions seen in some of the glacial clays. They are not seen in the upper till, Nos. 2 and 3.

JONES COUNTY.

The large cut on the Chicago, Milwaukee \& St. Paul railway about two miles east of Martelle, (Greenfield township, Township 83 North, Range 4 West, section 9) affords the interesting exposure illustrated in figure 9.

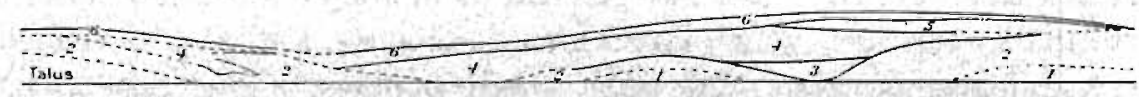

Fig. 9.-Diagram of cut on Chicago. Milwaukee \& St. Paul railway east of Martelle, Iowa, showing relations of Kansan till (1 and 2$)$; gray clay (8); Buchanan (?) gravel (4); Iowan (?) till (5): loess (6).

The generalized section is as follows:

Drift on Chicago, Milwadkee \& St. Paul Railway, Two Miles East of Martexle, Iowa.

Feet.

6. Clay (loess), pebbleless, thicker in sag than over the swells 1- 5

5. Till (Iowan?), lens-shaped bed, buff to gray, leached, pebbly 0- 5

4. Sand, buff to brown, over rusty gravel (Buchanan?) ..... 0.10

3. In a buried sag which the cut crosses obliquely is gray clay, nonealcareous and not well bedded in the upper part ("gumbo"-like), and laminated and calcareous below (Yarmouth?) .......................... 0 - 8

2. Till (Kansan), buff, leached 3-5 feet, calcareous below; exposed ............................... 15

1. Till (Kansan), calcareous, gray on dry face, dark slatecolored where moist; exposed .................... 1-10

In places at the top of No. 2 is a limy crust. or a line of concretions composed of the calcium carbonate leached from No. 3. The thin upper bed of till (No. 5) suggests a readvance of the ice after the deposition and weathering of the sand and gravel and the correlations indicated may perhaps be made. 
Professor Calvin ${ }^{13}$ gives the following log of a well bored on the gently undulating plain at a point three or four miles north of Martelle (Fairview township, Township 84 North, Range 4 West, section 20, near center). The log is said to be typical of a very large number of wells in this county.

Log of Werl ONe-Half Male Southwest of Fatrview, Iowa.

. Toam or vegetable

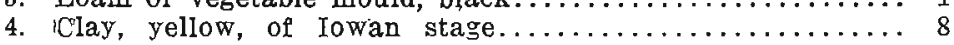

3. Dark brownish band, upper portion of Kansan stage....... 4

2. Blue unoxidized portion of Kansan stage............... 12

1. Sand in which occurs an abundance of water...........4 4 JOHNSON COUNTY.

One of the most significant exposures seen was the first cut north of Iowa river on the electric railroad about thirteen miles northwest of Iowa City (Jefferson township, Township 81 North, Range 7 West, section 2, southeast quarter). This was examined by Mr. Alden in 1905, and in 1912, 1913 and 1914 by Mr. Leighton who has published views and a description of the exposure ${ }^{14}$. The cut is in the lower slope seventy or eighty feet below the highest part of the ridge to the north and its base is not over thirty feet above the river.

NW.

SE.

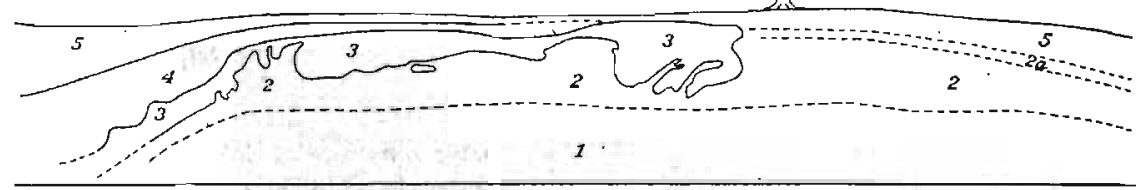

Fig. 10-Diagram of cut on electric railway near Iowa river, northwest of lowa City, Iowa, showing relations of Kansan till (1,2 and 2a); Buchanan gravel ( 3 ); Iowan till (4); loess (5).

Rising above the track level to a maximum height of about twelve feet (figure 10 and Plate VII) is dense, dark blue, calcareous till (No. 1) (Kansan.). This grades upward into buff to rusty brown, oxidized, partly leached till (Kansan) (No. 2) from nothing to ten feet thick. Overlying this is a bed of rusty brown gravel (Buchanan) (No. 3) which is partly cemented by iron oxide and in which the erystalline pebbles, which range in

\footnotetext{
${ }^{23}$ Iowa Geological Survey, Vol, V, p. 65, 1895.

i+Leighton, M. M., An exposure showlng post-Kansan glaciation near Iowa City, Iowa: Jour. Geology, Vol. 21, pp. 431-435, 1913. The Pleistocene history of Iowa river valley, north and west of Iowa City in Johnson County: Iowa Geologica. Survey, Vol. XXV, (1914) pp. 142-146, 1916.
} 
size up to one foot in diameter but are mostly less than three inches, are much decayed. The gravel bed is contorted and folded as if by pressure from the northwest. One of the synclinal folds is seven feet deep. Overlying the gravel is yellowish, blue-streaked till (Iowan) (No. 4) two to four feet thick across the summit and attaining a thickness of at least eight feet along the west monoclinal limb. This till is highly calcareous excepting in the upper few feet where it is leached. Yellow fossiliferous loess (No.5) lies on the northwest slope and loess and sand occur on the southeast or riverward slope.

This cut was reëxamined by Mr. Alden in June, 1915, and again in September, the last time in 'company with R. D. Salisbury, Frank Leverett, and George F. Kay. Beneath the southeast slope of the hill, in the lower end of the cut the relations are not entirely clear but there is here, below the loess, a thin bed of bluish gray clay (No. 2a) similar to the super-Kansan "gumbo." This rises westward in the section on top of the rusty jointed and weathered lower till (No. 2). Just below the trees, this is covered by only three feet of loess and soil. Immediately west of the trees (A) the crumpled bed of gravel shown in Plate VII comes in and the "gumbo" clay disappears. The crumpled condition of the weathered gravel bed and the presence of the overlying fresher till appears to be good evidence of a post-Kansan readvance of the ice at this place. The upper till, gravel, and lower till were carefully examined and pebbles collected from each. Secondary constituents, such as clay ironstones and calcium carbonate concretions were avoided. The results of the analyses as given in tables $I I, I V, V$ of $A p-$ pendix A show a higher percentage of greenstones in the upper till but no marked difference. The gravels have a higher percentage of granites and a lower percentage of limestone, and dolomite than either till.

Thirteen or fourteen miles southeast of this place in the first cut west of the river on the electric railroad at Iowa City (West Lucas township, Township 79 North, Range 6 West, section 9), there is exposed dense, dark, slate-colored till, regarded by Doctor Calvin as Kansan, and overlying it is rusty red gravel (Buchanan) twelve feet thick. Above the gravel is twenty-five 


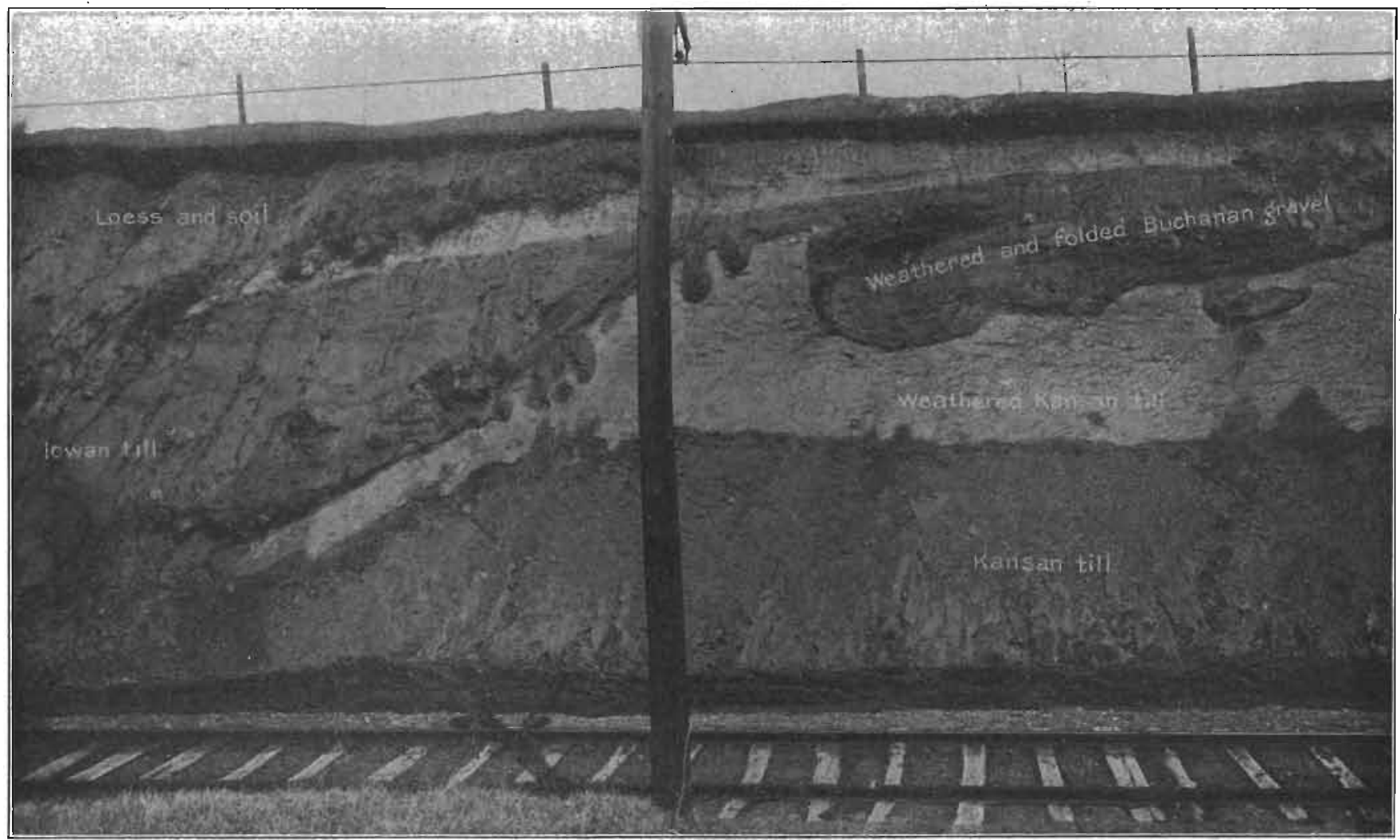

View of cut on interurban railway northwest of Iowa City, Iowa. 
feet of loess. This is about five miles southeast of what is regarded as the limit reached by the Iowan ice sheet. The absence of a till overlying the gravel and the undisturbed character of the deeply weathered gravel in this cut are in striking contrast with the conditions found in the cut in Jefferson township described above.

\section{CHAPTER V}

BOWLDERS.

\section{Bowlders in the Iowan Area}

Character and size-Discussions by former investigators of the Iowan drift have given prominence to the presence of notably large granite bowlders scattered over much of the Iowan drift, and these have been regarded as particularly characteristic of the Iowan drift.

These bowlders are dominantly coarse-grained granites, either light gray or pink, some so coarse that the term pegmatite is applicable. Basic rocks, greenstones, and quartzites are much less common and are not generally so large as the granites. Among the latter diameters of ten to twenty-five feet are common, and some measure as much as thirty-five, forty, or even fifty feet. The largest one known is in Floyd county, Riverton township, in the northwest quarter of the southwest quarter of section 22 (Plate VIII A). Its dimensions are fifty by forty by eleven and one-half feet above ground. A smaller piece which lies beside it and apparently is a fragment of the larger, measures seventeen by seven by one and one-half feet.

As a rule. the granites show some effects of surficial weathering, such as rounding of their angles and exfoliating shells. A few are badly decomposed, but most of them are far from being in an advanced state of decay. Slight accumulations of arkosic material lie in cracks and cavities, but otherwise most of the bowlders are relatively sound. 


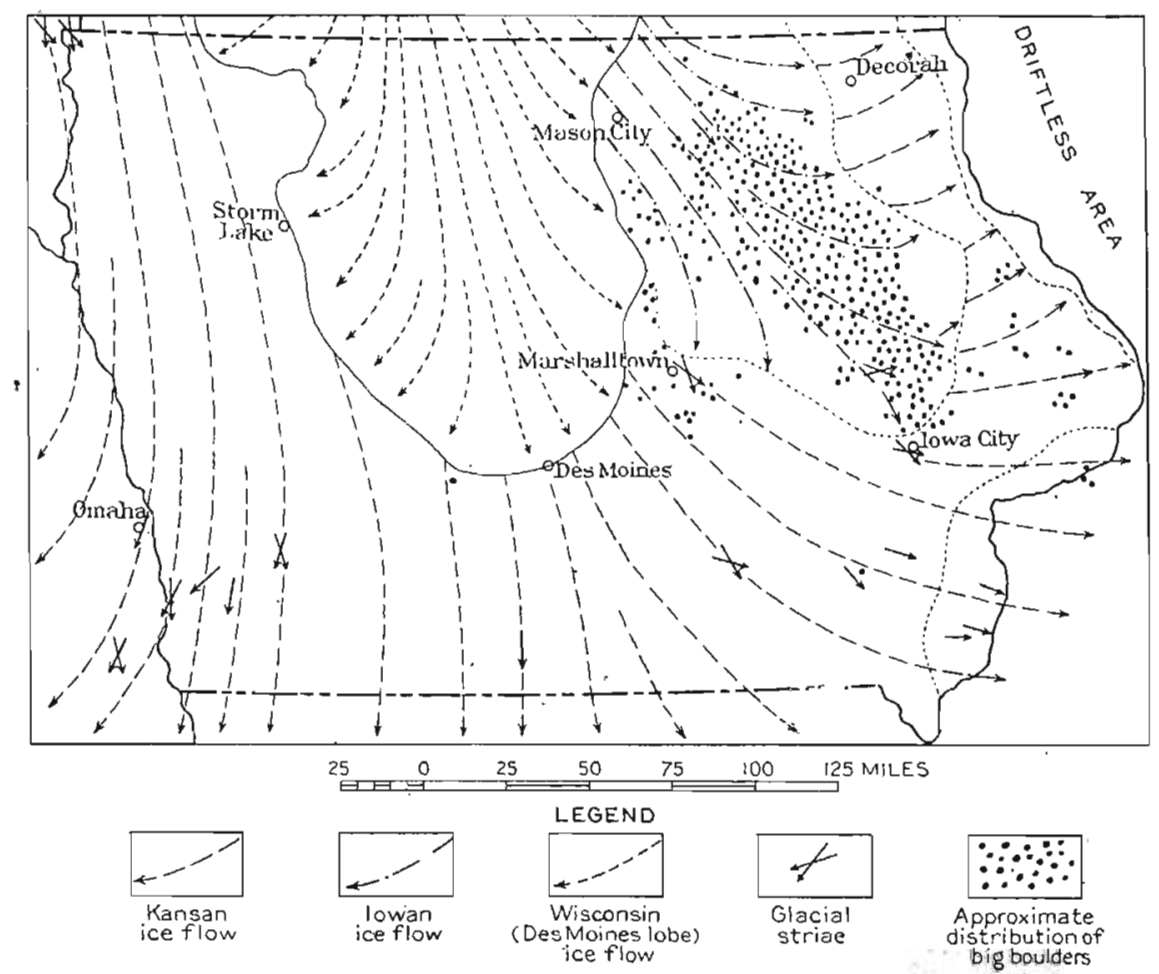

Fig. 11.-Diagram showing the distribution of big granite bowlders as related to probeblo dire-tions oi rovonent of te shets in Iswa.

Geographic Distribution-The big bowlders are most numerous in a broad belt, or bowlder train, extending southeastward in what was probably the zone of axial flow of the Iowan ice through Mitchell, Floyd, Chickasaw, southwestern Fayette, Bremer, northeastern Black Hawl, Buchanan, northeastern Benton, and Linn counties (figure 11). Not only are many large ones to be seen here, but smaller bowlders are numerous also, and are being used for foundations of buildings and, rarely, are piled as stone fences. Many of the smaller bowlders and some large ones are scattered both east and west of the main belt. In the southwestern part of the area bowlders, especially large ones, are much less numerous. In this part one may travel several miles without seeing more than a very few bowlders perhaps two or three feet in diameter, and then suddenly may come upon a huge one. 
Icwa Gesiorical Survey.

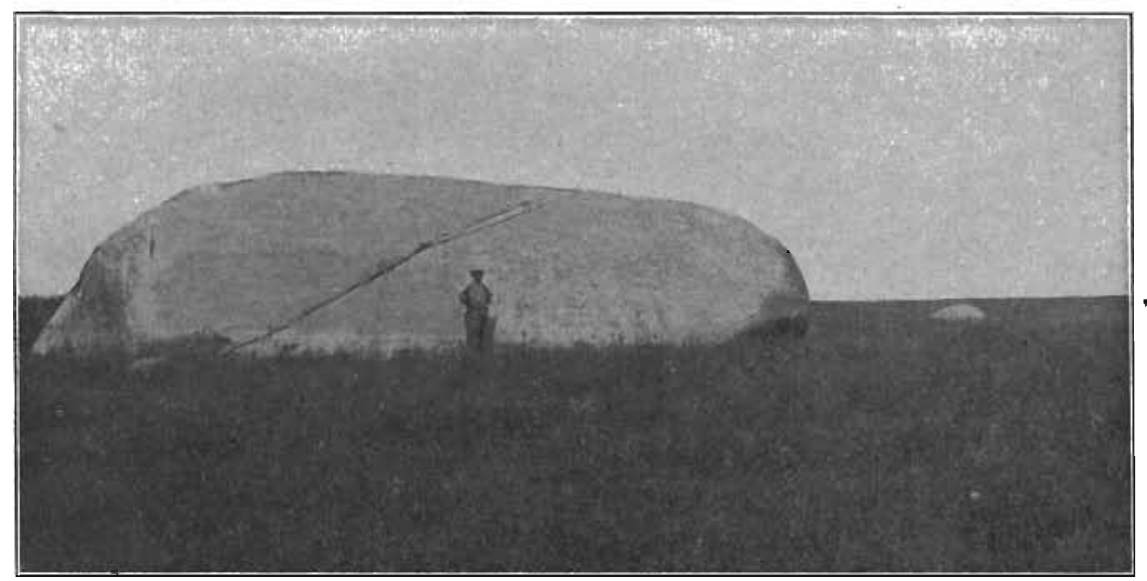

A. Large Iowan bowlder in Floyd County, Iowa.

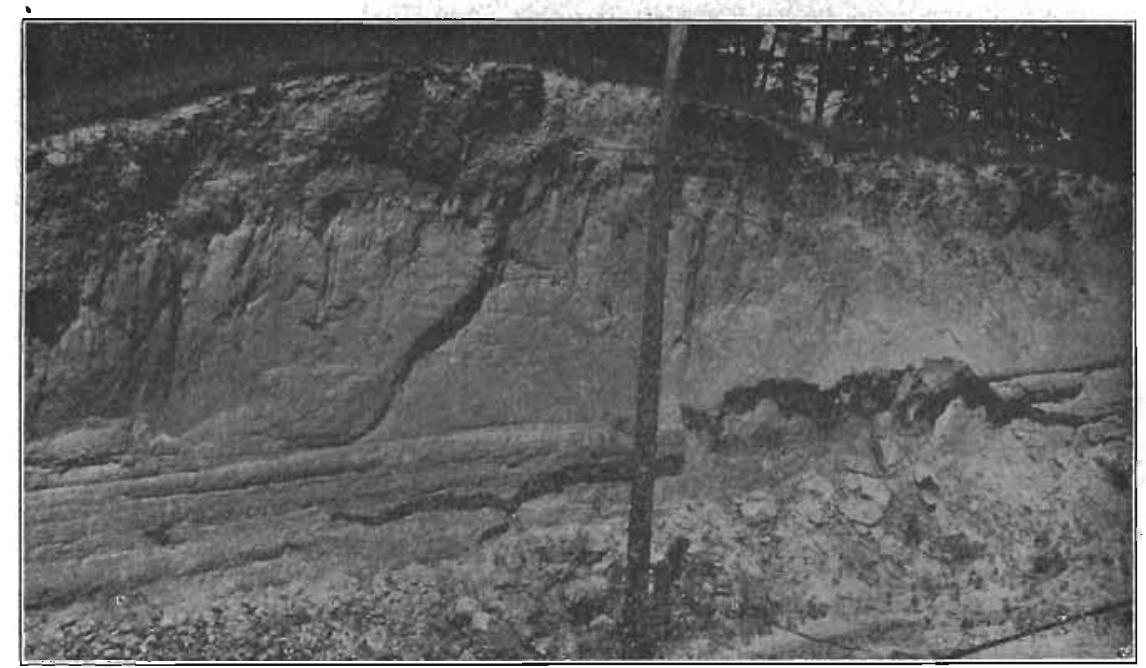

B. Vertical face of loess in railway cutting near Bertram, Iowa. 

Topographic Distribution-Some writers have described these bowlders as being confined principally to swales, or depressions in the slopes, and from this it has been inferred by some that most of the bowlders are the residue left on the removal of considerable drift by erosion when the broad open swales were being formed. It is true that most of the bowlders left scattered on the land at the present time lie in these swales, yet the writers' observations show that many erratics, both large and small, do occur on the uplands as well as in swales. This leads them to the opinion that originally the bowlders were seattered indiscriminately over uplands, slopes and swales. Since the region has been occupied by white men, however, nearly all the bowlders have been gathered from the tracts desired for cultivation, both in order to clear the land and in order to use the stone for foundations of buildings and abutments for bridges. Over a large part of the area the ground water level is so high that except in the driest seasons water seeps out of the lower slopes and in the bottoms of the shallow swales. These tracts, being wet lands, are not generally cultivated but are reserved as pastures for stock, and the farmers have not taken the trouble to remove the bowlders therefrom; hence at present most of the scattered bowlders lie in the swales. The typical Towan topography is apparently not due primarily to erosion since the last ice disappeared from the area, but is the result of mantling of an older mature erosion topography with a post-Kansan sheet of drift. It thus appears that the bowlders in the swales can not be regarded as the residuum of a much eroded drift sheet, and their presence in the swales can not be regarded as evidence of much erosion. Most of the bowlders evidently were left by the melting ice on the surface of the drift where they lay before man began his collection of them. Some are wholly or partly buried in the drift.

Doctor Calvin and others have shown that some of these bowlders have beveled surfaces and bear glacial striations, and thus show that they were transported, for a time at least, in the basal part of the ice. Such-striations were observed by the writers also. It is probable that the striations on many bowlders have been obscured by etching and exfoliation, inasmuch as the 
striæ seen are in most cases on surfaces which have been but recently uncovered by excavation.

Character of the Embedding Till.-Borings were made by the side of several partly buried big bowlders to determine the character of the embedding drift. These showed that the drift is the same yellow, moderately weathered till, which is leached to depths of three to five feet, as seen in most of the exposures, and which is regarded as Iowan.

\section{Bowlders in the Kansan Area}

There seems to have been a general impression that the large granite bowlders in Iowa are strictly confined to the Iowan drift area. ${ }^{15}$ Indeed, the presence of large granite bowlders in some outlying tracts has been taken to indicate the presence of Iowan drift. The supposed lobe of Iowan drift in southwestern Tama county was mapped partly because of the presence of such bowlders ${ }^{16}$. And in Jasper county, in certain townships which have the aspects of Kansan topography, the occurrence of one bowlder with a diameter of thirty feet and of other large ones of granitic composition led Mr. I. A. Williams to postulate an extension of the Iowan ice into that area to explain their presence $^{17}$.

It appears, however, that occasional large granite bowlders occur farther south in Iowa, some of them remote from the Iowan drift area (figure 11). Several erratics with diameters of ten to thirty feet have been reported from Lucas county. ${ }^{18}$ In section 32 of Center township, Wapello county, A. G. Leonard found a fine-grained granite measuring six by twelve by five feet $^{10}$. J. A. Udden reports finding in section 15 of Walnut township, Jefferson county, ${ }^{20}$ a porphyritic granite seventeen by twelve by seven feet in size. Besides these some granites ten feet in diameter were noted in Henry county. ${ }^{21}$

During the present investigation several other large bowlders were seen in the Kansan area. Of these, three were in Marshall

\footnotetext{
${ }^{15}$ Calvin, Samuel, The Iowan drift: Jourt. Geology, Vol. XIX, p. 599, 1911.

JoSavage, 'T, E., Iowa Geological Eurvey, Vol. XIII, p. 200, 1903.

ITIowa Geologtcal Survey, Vol. XV, pp. $288-290,1905$.

19Kay, G. F. in a personal communication.

19owa Geological Survey, Vol. XII. p. 439, 1902

Nowa Geolorical Survey, Vol. XII, p. 358,1902

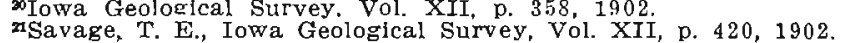


county; one in Logan township. in the southeast quarter of section 4, which measured ten by four by six feet; one in the central part of section 8, Eden township, which measured fifteen by fifteen by three feet; and one in the southwest quarter of section 33, Timber creek township, which measured eight by five by three feet. In Jasper county a bowlder with a diameter of ten feet was seen protruding from a cut on the Chicago, Rock Island and Pacific railway, six miles east of Kellogg. In Cedar county, in the northwest quarter of section 21, Gower township, another bowlder with a diameter of ten feet was found. MeGee reported ${ }^{22}$ other large bowlders as occurring near Davenport, Iowa. Big bowlders also occur in the northwest and southwest parts of Jackson county, near Epworth in Dubuque county, and in Clinton county, at places to which it is doubtful if the Iowan ice extended.

Professor Savage ${ }^{23}$ also reports considerable numbers of bowlders as occurring northeast of Maquoketa in Jackson county. "Many of these," he states, "are of exceptionally large size for drift of their age (Kansan), the larger masses having a diameter of six to nine feet."

\section{Big Bowlders As Evidence of Iowan Glaciation}

Inasmuch as large granite bowlders occur outside the Iowan drift area, it is apparent that some such bowlders were carried by the Kansan drift There is, therefore, some question as to how far the big bowlders within the supposed limits of the Iowan drift can be regarded as evidence of a distinct post-Kansan ice invasion.

In this connection it is well to consider the direction of movement of the Kansan ice which spread over the eastern half of the state (figure 11). Several observations of glacial striæ have been noted. In 1914 striæ were found on limestone underlying the Kansan drift at Kuhnle's quarry at Charles City, Floyd county, trending south-southeast. Professor S. W. Beyer ${ }^{24}$ observed striæ in Marshall county, in LeGrand and Timber Creek townships, trending south $20^{\circ}$ to $25^{\circ}$ east. Professor W. H.

mU. S. Geol. Survey Eleventh Ann. Rept., p. 482.

mavage. 'T. E., Iowa Geological Survey, Vol. XVI, p. 634, 1906.

Mowa Geological Survey, Vol. VII, pp. 239-240, 1897. 
Norton ${ }^{25}$ found two sets of striæ at the quarry one and onefourth miles northeast of Quarry Station (Section 1, LeGrand township, Township 83 North, Range 17 West); one bearing soutl $22^{\circ}$ east to south $47^{\circ}$ east; the other, south $35^{\circ}$ to $64^{\circ}$ west. Dr. H. F. Bain ${ }^{28}$ reports the observation of strix at Eddyville near the south line of Mahaska county. These consisted of an earlier set trending south $42^{\circ}$ east and a later set trending south $70^{\circ}$ east. Doctor J. A. Udden ${ }^{27}$ observed obscure striæ northeast of Perlee in northeastern Jefferson county. The trends are given as south $35^{\circ}$ east, and south $75^{\circ}$ west. Possibly the direction of movement making the latter may have been north $75^{\circ}$ east, since so westerly a direction of movement at this place of either the Kansan or pre-Kansan ice seems rather doubtful, while local northeasterly deflection is quite possible.

At Brighton in southwestern Washington county striæ reported by $H$. F. Bain ${ }^{28}$ trend south $4^{\circ}$ to $6^{\circ}$ east with a few scratches south $6^{\circ}$ west to south $4^{\circ}$ east. Not far away on Crooked creek striæ were seen trending south $67^{\circ}$ east. In a paper "Glacial scorings in Iowa,"' C. R. Keyes ${ }^{28}$ cites observations of strix near Iowa City, as reported by MeGee, Calvin, and others, trending south $52^{\circ}$ to $62^{\circ}$ east. Striæ trending south $70^{\circ}$ to $73^{\circ}$ east were observed also near the western end of the electric railway bridge at Iowa City by W. C. Alden.

W. H. Norton ${ }^{30}$ discovered striæ at an old cut on the Chicago, Milwaukee \& St. Paul railway five miles northwest of Cedar Rapids, Linn county; (one mile west of Linn Junction) ranging south $79^{\circ}$ east to east $14^{\circ}$ north.

In 1915 W. C. Alden observed a finely glaciated ledge recently exposed in grading a road six miles east of Delmar, Clinton county (Watêrford township, Township 83 North, Range 4 East, section 21 , southeast quarter). Here the striæ trend east $11^{\circ}$ north.

Towa Acad. Science, Vol. 18, pp. 80-83, 1911

Towa Geological Survey, Vol. IV, p. $343,1895$.

${ }^{27}$ Iowa Geological Survey, Vol. XII, p. 431, 1902.

${ }^{28}$ Iowa Geological Survey, Vol. V, p. i5s, i896.

Towa Geological Survey, Vol, TI. pp. 148-165, 1894

${ }^{30}$ Iowa Acad. Sclence, Vol. 18, pp. 80-83, 1911. 
Somewhat doubtful striæ bearing east $43^{\circ}$ north were seen by the writers on a limestone ledge in the road at a point about one mile southwest of Monticello, Jones county (Monticello township, Township 86 North, Range 3 West, section 33, northeast quarter).

If these several striæ, or even most of them, were made by the Kansan ice, as seems probable since most of them are outside the area of the Iowan drift, they show something as to the direction of the ice flow reaching these parts of Iowa. If one may judge from these as well as from general consideration of the eastern limit of the drift in northeastern Iowa, the Kansan ice in the eastern half of the lobe which invaded lowa radiated eastward, the directions of flow shifting from south $20^{\circ}$ or $25^{\circ}$ east in Marshall county, to south $70^{\circ}$ to $73^{\circ}$ east in Johnson county, east $10^{\circ}$ north in northern Clinton county, and thence in northeastern Iowa also toward the east. Ice currents crossing Johnson county thus must have swung eastward to the vicinity of Muscatine and Davenport. Thus the main stream of Kansan ice which crossed northeastern Iowa where are now most of the big bowlders, probably did not reach the Kansan area south of the Iowan drift boundary. Some big bowlders certainly were carried by the Kansan ice. If only that part of the ice flow which spread over northeastern Iowa crossed the ledges yielding most of the massive blocks of granite, the distribution of the big bowlders would be such as we now find it to be even had there been no post-Kansan ice invasion. The big bowlders of southern Iowa are few but it was also noted that the big bowlders are much less abundant in the southern part of the Iowan drift area west of Linn county than farther north, so that if such bowlders were carried by the Kansan ice it might be expected that but few would be seen in the Kansan area west, southwest, and south of Johnson county.

Judging from their distribution alone, therefore, it would seem that the big Iowan bowlders could just about as well be referred to transportation and deposition by the Kansan ice as by the post-Kansan glacier. The writers are therefore not inclined to place very much weight on these erratics, taken by themselves, as evidence of a distinct post-Kansan glaciation of 
northeastern Iowa. It is, however, a notable fact that by far the larger part of the big bowlders of Iowa, probably 99 per cent of them, occur within the supposed limits of the Iowan drift, and taken in connection with the other evidence they may be said to support the theory of a post-Kansan glaciation.

\section{CHAPTER VI.}

\section{IOWAN OUTWASH AND OTHER GRAVELS.}

In accordance with the evidence already presented which indicates that there really is an Iowan drift-sheet, it would be expected that outwash gravels of post-Kansan and pre-Wisconsin age would be found in valleys which received the drainage from the Iowan ice.

VALLEY TRAIN TERRACES.

In practically all of the valleys of northeastern Iowa there are gravel deposits. A few of the valleys head in the area of the Wisconsin drift and much of the gravel in these probably is Wisconsin outwash. The rest of the valleys, however, head in the Iowan drift area and much of the gravel in these probably is Iowan outwash.

It may be well to give some details as to the occurrences of gravels near and outside of the limit of the Iowan drift. These deposits were carefully examined at many places. None of the valleys was studied throughout its full extent and the relations to the gravel deposits on Mississippi river have not been determined.

Starting at the north in Howard county, a gravel terrace was observed fifteen to twenty feet above Upper Iowa river at and west of Florenceville, Iowa, and Grainger, Minnesota. Near the state line a cut south of the bridge showed coarse gravelly material composed mostly of limestone fragments, partly angular and partly waterworn, with some intermingled crystalline pebbles, but the gravels here appeared more like the material of a local alluvial fan than glacial outwash. Ten Mile creek heads in a broad open swale east of Ridgeway. At the point where the 
Iowan drift boundary has been mapped as crossing, the valley narrows sharply and the stream enters a gorge between bluffs of shale. One would expect to find here a well-marked deposit of gravel washed out from the Iowan ice front, but none was noted in the two or three miles traversed.

There is some development of a terrace in the Upper Iowa river valley above Decorah, but this was not examined. Well marked terraces occur at points below this place. About a mile north of Freeport interesting exposures of old drift and of fresher gravel were seen. The relations are shown in figure 12.

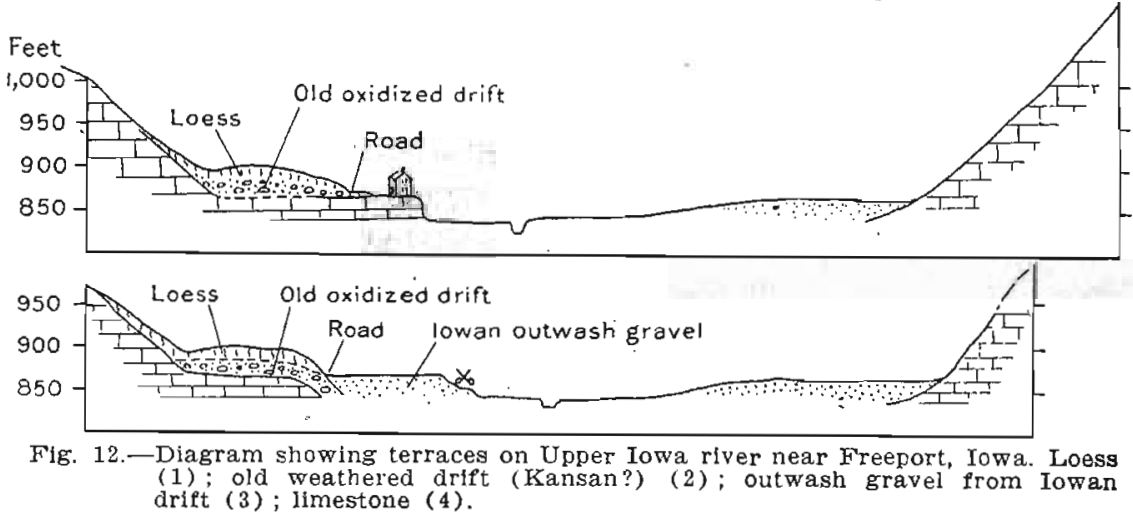

At this place (Decorah township, Township 98 North, Range 8 West, section 12, southwest quarter) A. M. Sheets has a gravel pit in a remnant of a terrace just below the road. The stratified sand and gravel exposed here (eight feet) are fresh, clean, and unoxidized. The pebbles are largely of limestone with intermingled cherts, quartzites and crystallines. It seems probable that this fresh-looking gravel is outwash to be correlated with the Iowan stage of glaciation. The house stands on a terrace just south of the road at about the same level, but underlain by limestone and sandstone. Just west of the house and above the terrace, deeply weathered red gravelly drift is exposed in the road cut. No limestone pebbles were found in this, only cherts, quartzites and dense fine-grained crystallines. It is probable that this is at least as old as the Kansan stage, as is also that on top of the bluff near the Freeport bridge. Farther down the valley in Glenwood township, (Township 98 
North, Range 7 West) limestone gravels were seen at several points, notably at the new dam and powerhouse in section 8 .

Doctor Calvin ${ }^{31}$ describes these gravels, referring to them as "deposits of uncertain age, probably Kansan." He writes, "Along the river from the county line westward, in the southeast quarter of section 36, Pleasant township, the terraces are well developed. Not far from the line the stratified terrace materials have been undercut by the river so as to show a fresh section forty feet in height. Near and below the middle of the section there are many coarse blocks from the Oneota and Saint Peter formations, but the main body of the deposit consists of rounded fragments of chert and local limestone, with some pebbles of quartz, diorite, granite and other northern crystallines, all embedded in quartz sand. Some small streaks made up almost exclusively of northern pebbles and quartz sand are iron stained and resemble the ordinary Buchanan gravels. Between section 36 of Pleasant township and section 16 of Decorah, there are many remnants of the same terrace deposits." Doctor Calvin regarded only the deposits of fresh clean sand, such as that on the southeast side of the valley northeast of Freeport, as outwash from the Iowan ice.

There is a gravel terrace on North Branch of Turkey river south of Cresco (section 2, New Oregon township), fifteen feet above the stream. Similar deposits were also seen at points farther down stream in Winneshiek county, west and southwest of Ridgeway. Four miles south of this place (Sumner township, Township 97 North, Range 10 West, section 11, northeast quarter) the sand and gravel terrace stands twenty feet above the stream. At and near Spillville is a fifteen-foot gravel terrace. Below this the valley is largely a narrow winding gorge. Remnants of the terrace were seen down to and below Fort Atkinson. This place stands on a bench which appears to be underlain by gravel. About two miles farther southeastand one and one-half miles west of Festina, the gravel terrace is well developed near the bridge. Twenty feet above the present flood plain an exposure in the cut bank showed two feet of brown loamy soil overlying the gravel from which the lime-

"Iowa Geologlcal Survey, Vol. XVI, p. 124. 
stone pebbles had been removed by solution to a depth of six feet (that is, eight feet from the surface). Below this the gravel contains plenty of waterworn pebbles of limestone and some angular fragments. Gravels head in some of the tributaries on the west, but one is somewhat surprised not to see them more markedly developed in situations where there were such direct lines of drainage from the Iowan ice front.

The streams at and near Waucoma are bordered by a gravel terrace about twelve feet above the flood plain. At one point where an examination was made no limestone pebbles were noted within eight feet of the surface. In Fayette county a terrace is well preserved above, at and below Eldorado, in which the gravel is largely composed of limestone pebbles. Near the bridge in section 35, Dover Township (Township 95 North, Range 8 West), this bench stands about thirty feet above the stream and there are plenty of limestone pebbles with the crys-. tallines. There is also a large terrace remnant at the east line of the township. The towns of Clermont and Elgin stand on broad remnants of this terrace. The Chicago, Rock Island \& Pacific Railway has a large pit in the well stratified gravels north of Elgin. At the latter place the terrace is about twenty feet above the broad flood plain. Where they were examined near the cemetery, the gravels are rusty in the upper part, but the crystalline pebbles are fresh and sound and limestone pebbles were plentiful below five feet from the surface.

In his report on Fayette count: ${ }^{32}$ Prof. T. E. Savage referred the deposition of these gravels to waters from the Kansan ice sheet. Those seen by the writers, however, appear quite fresh enough to be correlated with the Iowan stage of glaciation. In his recent volume on the Pleistocene Mammals of Iowa ${ }^{83}$ Dr. O. P. Hay makes the following reference to these gravels:

Near Clermont. In Nettie C. Anderson's list, page 28, Prof. T. E. Savage reported a mastodon tooth from near Clermont, which was in the possession of Mr. C. E. Allen, of Clermont. Mr. Allen has sent the writer a drawing which shows that the tooth is that of Elephas, probably Elephas primigenius. Professor Savage has kindly informed the writer that the tooth

${ }^{82}$ Iowa Geological Survey, Vol. XV, pp. 451-53.

31owa Geological Survey, Vol. XXIII, pp. 433 and $434,1913$. 
came from materials filling the valley of Turkey river. $\mathrm{He}$ believes that these were deposited during the melting of the Wisconsin ice-sheet. If this is true, the animal which bore the tooth lived at the close of the Wisconsin stage or afterwards. Near this same place was found a part of a skull of the musk-ox Ovibos moschatus. Mr. Allen states that the tooth was taken out of the gravel pit of the Rock Island Railway between Clermont and Elgin, Iowa, and that it was found at a depth of about twenty feet. The tooth, or what remains of it, is in the possession of Mr. Allen.

The present writers regard this gravel as of Iowan rather than Wisconsin age. The terrace is reported by Prof. A. G. Leonard ${ }^{34}$ to be fifty-five feet above the stream at Elkader, where much of the town east of the river is built upon it, and at Osterdock it is sixty feet above the river.

The valley of Otter creek between West Union and Elgin was not examined for outwash gravels.

Volga river, a tributary of Turkey river, receives drainage from the Iowan area from the vicinity of West Union to Edgewood in southwestern Clayton county. The lower part of Fayette is built on a well marked terrace ten to fifteen feet above this stream and below the bench on which stands Upper Iowa University. At the mouth of this branch of the valley at Albany is a broad gravel terrace.

At and above Wadena the gravel terrace is twenty-five to thirty feet above the stream. The main part of Volga stands on a terrace of fine gravel which occupies a broad abandoned channel surrounding the low hill on which is the cemetery. West of town a pit in the edge of the terrace showed three feet of sand over five feet of sand and fine iron stained calcareous gravel. This terrace is twenty or thirty feet above the present stream.

The tributaries from the south have a fall of 300 to 400 feet in distances of three to six miles between the border of the Iowan drift and Volga river. They are in sharply cut valleys which, so far as was seen, do not contain outwash deposits. They"were not, however, carefully examined. From a point about three miles east of Greeley, Delaware county, southeast

अIowa Geological Survey, Vol. XVI, pp. 287-288. 
nearly to Dyersville the drainage is toward rather than away from what has been mapped as the Iowan border.

A gravel terrace stands twelve to twenty feet above the streams just north and northwest of Dyersville, also south of this place and at Worthington. With these may belong the terrace gravels seen on the same stream at Fulton and Hurstville, north of Maquoketa in Jackson county.

Well preserved remnants of terrace gravels were examined at many places along. Maquoketa river from Manchester to Maquoketa. The former place is built upon a broad flat beneath which wells penetrate as much as forty feet of gravel, an amount sufficient to divert the river over limestone ledges. Southeast to Hopkinton the terrace stands twenty to twenty-five feet above the stream. The gravels are well exposed at the mouth of the gorge traversed by Lime creek and also west of the point where this stream enters the gorge on its way down from the upland. Doctor Calvin" in describing the terrace states that "excavations show that the main body of this terrace is made up of very old, weathered, ferruginous material of the age of the Buchanan gravels"; also:

It is interesting to note that the terraces observed in this county are nearly all referable to the period of ice melting following the invasion of the Kansan glaciers. In some cases there have been some additions to the terrace deposits in times more recent than the Buchanan gravels, but the significant point is that these valleys are pre-Kansan in origin.

The gravels where seen by the present writers seem not too old to be regarded as Iowan, while other evidence cited above (page 71) seems to show that the valley cut in the limestone is itself of post-Kansan rather than pre-Kansan age, at least in the part examined.

Four miles south of Lime ereek, only the upper leached part of the gravel was seen.

At and north of Monticello the terrace is well preserved. Exposures show the gravels to be well stratified and crossbedded. They are noncalcareous, partly fresh and partly rusty. Though the gorge below Monticello is narrow and winding remnants of the terrace were noted at many points. The pebbles

"Iowa Geological Survey, Vol. VIII, p. 176. 
in the sand are mostly fine but range in size up to eight or ten inches; the crystalline pebbles are mostly sound and hard, not much decomposed. But few limestone pebbles were found. The village of Canton at the east line of Jones county stands on a bit of this terrace.

A terrace near Newport is well preserved and north of Olin on Wapsipinicon river, and at the bridge between Hale and Oxford is a terrace of fine sand and gravel twelve to thirteen feet above the stream.

Rochester, on Cedar river south of Tipton, stands on a gravel terrace, but not much attention was given to deposits along this stream. Some of these, such as those on the broad flat opposite and above Cedar Bluff, may have resulted from slackwater during the Illinoian stage. Such slackwater must have occupied the valley as far up as Ivanhoe bridge southwest-of Mount Vernon.

In the Iowa river valley, below the North Liberty lobe, there are terrace remnants of probable Iowan age. It does not seem likely that these are Wisconsin, since terraces of that age play out before reaching Marshalltown and since the terraces to which reference is here made are mere remnants at the bends of the stream. A similar terrace on Pardieu creek about four miles north of Iowa City (Penn township, Township 80 North, Range 6 West, section 29) is regarded by Mr. Leighton as composed of outwash from the North Liberty lobe of the Iowan ice. ${ }^{36}$

The gravels distributed along the courses of the streams within the Iowan area, but which do not head in the Wisconsin drift area, were probably deposited by the outflowing waters as the margin of the Iowan ice sheet retreated across the area during the final stage of melting. Such gravels are well developed in the Wapsipinicon river valley. at Central City, Linn county, at Quasqueton, Buchanan county, and east of New Hampton, Chickasaw county; in the Little Cedar river valley at Bassett, Chickasaw county, at Stacyville, Mitchell county, and in the valleys of numerous small streams.

State of weathering.-As noted above, these gravels are unconsolidated and moderately fresh in appearance. Decayed

${ }^{26}$ Leighton, M. M., Additional evidences of Post-Kansan glaciation in Johnson County, Iowa : Proc. Iowa Acad. Scl., Vol. 20, pp. 251-256, 1913. 
pebbles and whole ironstone concretions are comparatively few, though there are numerous fragments of ironstone concretions, as if these had been derived from such older gravel-bodies as the Buchanan. The amount of solution which the limestone pebbles have suffered is considerable. This varies according to the coarseness of the material. Fine sandy gravel commonly contains no limestone pebbles in the upper ten to twelve feet, whereas in coarser materials calcareous constituents have been removed to depths of three to five feet. Gravel of the latter sort was exposed in the Chicago, Anamosa \& Northern Railway pit near the depot in Quasqueton, Buchanan county, on a terrace of Wapsipinicon river. The upper three to four feet of the gravel contain cherts, greenstones, granites, dense igneous rocks, and quartz, with no limestone, whereas below there are many irregular fragments of limestone as large as four to six inches.

In Chickasaw county, one mile west of Bassett, the Chicago, Milwaukee \& St. Paul Railway has a. large gravel pit nearly fifteen feet deep in a well developed terrace bordering Little Cedar river. The gravel consists mostly of pebbles half an inch to an inch and a half in diameter. The limestone constituents seem to have been removed by solution to depths of eight to twelve feet from the surface.

THE ABSENCE OF GLACIOFLUVIAL GRAVEL IN CERTAIN VALLEYS OF THE KANSAN AREA.

It appears from the literature of the Kansan drift of southern Iowa that there is a general absence of gravel terraces irom that area. 'So far as the present writers have had opportunity to examine the valleys this seems to be true of those which do not reach into areas of younger drift. This opposes an interpretation which regards the gravels described above as due to increased erosion of drift on the slopes and deposition in the valleys during the Wisconsin stage or at any other post-Kansan time. The lack of erosional details on the slopes of the Iowan drift also opposes this view. These gravel terraces are, therefore, regarded by the present writers as composed of glacial outwash of Iowan age.

UPLAND GRAVEL.

Two phases of upland gravel were found throughout the Iowan area, which appear to be of two distinct ages: Kansan and Iowan. 
Iowan Kames.-Reference is elsewhere made to the occurrence of morainal knolls of relatively fresh gravel in Winneshiek county. Besides these, knolls of similar material were seen in Howard county, Sumner township, in the eastcentral part of section 5 and the west-central part of section 4 ; and in Mitchell county, Cedar township, in the northwest quarter and northeast quarter of section 5. Deposits of upland gravel, not in distinct knolls and showing moderate weathering, were also examined in Linn county, Jackson township, central part of section 21, and in Delaware county, Oneida township, west line of the southwest quarter of the northwest quarter of section 12. Limestone pebbles are present in most of these below depths of three to five feet. Comparison of the amount of weathering of the upland gravels and of the gravel terraces of the Iowan area, taking into consideration their topographic positions, indicates that the gravels are probably of the same age.

Kansan Kames.-At many places in the Iowan area, and especially in Buchanan county near Independence, there are low rounded knolls on the upland which apparently belong to an older deposit. These knolls contain highly oxidized and decayed ferruginous gravels, with an abundance of ironstone concretions and disintegrated granites, greenstones, and other igneous rocks. The surfaces of some of the quartzites even show etching. Calcareous material is generally lacking, having been removed by solution. Everywhere the gravels have a distinct brown color, and in all respects show great age. The materials range in size from sand to small bowlders a foot in diameter. The smaller pebbles, and many of the larger ones, can readily be cut in two by a chisel-edged hammer. These gravels are better for roadmetal than those of the Iowan or Wisconsin terraces, as their more advanced state of decay permits them to pack well. Professor Calvin called these deposits Buchanan gravels and considered them as having been deposited as the Kansan ice sheet was melting away. Since they occur as knolls on the upland, it appears that they are of the nature of kames. Some of the knolls are thinly mantled with younger drift (Iowan). 
COMPARISON WITH GRAVELS OF WISCONSIN AGE.

Wisconsin valley-train gravels were examined somewhat in Cerro Gordo, Floyd, Franklin, and Hardin counties. The amount of leaching of these is much less than in those of the Iowan terrace gravels and other alteration is less also. Limestone pebbles occur up to the soil or within two feet of the surface. The erosion of the Wisconsin terraces is also considerably less. There can be little question but that the gravels here regarded as Iowan are older than those washed out from the Des Moines lobe of the Wisconsin stage.

\section{SUMMARY.}

The chief facts which were noted in the field regarding the gravel phenomena are:

1. Terraces of glacio-fluvial gravel occur in all the major valleys in the Iowan area and continue for some distance beyond the limit of the Iowan into the Kansan drift area. Those in the Wapsipinicon, Maquoketa, Volga, Little Turkey, Turkey, Upper Iowa, Little Cedar, and certain smaller valleys have no other source than the Iowan area.

2. So far as noted valleys in the Kansan area which do not head in areas of younger drift do not contain gravel terraces.

3. The sand and gravel of the Iowan terraces are moderately weathered.

4. Some small gravel knolls occur in connection with local morainic features of the Iowan area. The materials of these are weathered similarly to the Iowan terrace gravels.

5. Here and there in the Iowan drift area there are low rounded knolls of much-decayed gravels (Buchanan). These gravels are probably of Kansan age. Some of them are mantled with the later drift.

6. The Iowan gravels are considerably more weathered and eroded than the Wisconsin gravels.

These facts support the theory that an ice sheet invaded northeastern Iowa at a time considerably later than the Kansan and some time prior to the incursion of the Des Moines lobe of the Wisconsin ice sheet. 


\section{CHAPTER VII \\ THE LOESS AND ITS SIGNIFICANCE.}

One cannot work in the area of the Iowan drift or adjacent areas of older drift without being confronted with the problem of the loess. The writers did not undertake an exhaustive study of the various deposits of loess but some observations were male which have direct bearing on the main question under investigation. Deposits of loess known to be of pre-Iowan or of post-Wisconsin age are not included in the following discussion, excepting as specifically indicated. This does, however, refer to the main body of loess in the Upper Mississippi valley region.

GENERAL CHARACTERS.

Earlier students have shown that the constituents of the main body of loess of the Upper Mississippi Valley are such as would be derived from glacial rock flour, that is, such as might be blown from the surface of the drift or from the flood plains of valleys draining a drift area. ${ }^{37}$ The loess is a fine-textured, dustlike silt, buff in color as seen in most shallow exposures, and gray in the lower parts of deeper ones. Generally, when rubbed between the fingers, it feels floury. From this it varies locally to sandy and not infrequently is it found closely associated with wind-blown sand, especially in the lower part. There are also in places intercalated layers of fine sand. The writers have not observed coarse sand or pebbles included in what they would regard as undisputed loess. In parts of many clean exposures there is a more or less definite banding or semblance of stratification, usually conforming to the surface or slope on which the deposit lies. A sort of flakiness also has been noted, suggesting stratification, but clear-cut lamination, so characteristic of glaciolacustrine silts, is rarely if ever seen; so also definite crossbedding is comparatively rare and such as is seen suggests eolian rather than stream deposition. There are also faint dark colored lines here and there which may be the residue of carbon from vegetation buried during the deposition of the loess. ${ }^{\pi}$ Chamberiin, T. C., and Salisbury, R. D. Preliminary paper on the driftless area of
the Upner Mississippi Valley: U. S. Geol. Survey Sixth Ann. Rept., pp. 281-283, 304305, 1885. Chamberlin. T. C., Supplementary hypothesis respecting the origin of the loess of the Misslssippi Vajley: Jour. Geology, Vol, V, pp. 794-802, 1897 . 
One of the notable characteristics of the loess when it is dry is vertical cleavage (Plate VIII B). Unprotected, nearly vertical faces will stand for years without slumping and even retain for a long time marks of the excavator or "jack-knife carved initial." This peculiarity probably results from homogeneity of texture and interlocking of the minute angular particles of which it is composed, combined, perhaps, with incipient cementation by iron oxide or calcium carbonate as the result of alternate wetting and drying.

The loess bordering and overlapping the Iowan drift area is rarely thicker than thirty feet and in most places there is less than fifteen feet.

THE FOSSIL CONTENT AND ITS SIGNIFICANCE.

In many places the calcareous part of the loess contains small shells. These vary in size from tiny spirals to shells half an inch or more in length. In some places they are numerous, in others moderately so, in still others rare or absent.

Professor Bohumil Shimek, of the University of Iowa, has made an extensive study of the character, composition, relations and fossils of the loess and has published his results in a long list of papers covering a period of twenty-five years. The chief points of significance to which he has called attention in these several papers ${ }^{38}$ are: (1) the shells are preponderantly of land snails; (2) they are identical in most cases with those of snails now inhabiting damp, shady places and feeding on vegetation in the same localities; (3) the small percentage of fresh-water forms which are found are similar to those which now live in seepy places on slopes and in ponds; (4) many of the shells are fragile, yet generally nearly perfect in their preservation.

These and other facts as to texture, composition, geographic and topographic distribution indicate, according to Professor Shimek, that the loess was deposited by wind, that the sites of deposition were clothed with vegetation, and that the climate was much like the present, in other words interglacial. $\mathrm{He}$ writes $:^{39}$

\footnotetext{
${ }^{38}$ Shimek $B$ The loess and the Lansing man: Bull Lab Nat. Hist. State University of Iowa Vol. $V$, pp 327-346, 1899-1904 Loess and the Iowan drift: Bull. Lab. Nat. Hist., State University of Iowa. Vol. V, pp. 352-367. 1899-1904. The significance of Pleistocene mollusks: Sclence (New Ser.), Vol. XXXVII, pp. 501-509, 1913.

aSclence, N. S., Vol. XXXVII, p. 508 .
} 
The only conclusions then which can be drawn from the fossils of the loess is that during the deposition of the several loesses climatic conditions were not materially different from those which exist in various parts of the same general region today. Such differences as do exist point rather to a drier climate in the northern part of the loess-covered area than that of today.

Since no plant remains have been found in the loess, he argues that the rate of deposition was slow, so slow that the generations of trees and other plants had time to decay and their humus residue to be dissolved out before being buried to depths sufficient for preservation.

Most of the foregoing conclusions seem sound. The great predominance of land shells and the relative scarcity of aquatic forms, together with the peculiarities of its topographical distribution, have had considerable influence in leading many to an acceptance of the eolian theory of origin of the loess. It is not 'always possible, at least without very careful study, to determine that the loess at any given exposure has not been modified or moved since its original deposition. So it is probable that in many cases some of the textural properties of the loess as seen are due to other factors, mainly secondary, such as rehandling by slope-wash, creep and slump, some local deposition in transitory ponds, disturbance by burrowing animals, penetrating roots, and uprooting of trees, frost action, removal of soluble constituents by percolating waters and their redeposition as layers, concretions or tubules - that all of these and perhaps others have contributed to its present physical properties.

With allowance made for such factors the eolian theory of origin for the loess which borders and overlaps the Iowan drift seems to the writers to meet most, if not all, of the requirements of the case if a source of the material is available.

MODIFICATION OF THE LOESS BY WEATHERING.

Wherever thicknesses of eight feet or more of loess have been seenin cuts along the border of the Iowan drift, there is usually a gradation downward from leached to calcareous loess in the lower part. A few feet below this gradation zone the loess 
changes color from buff to gray. The features of an average exposure are given in the following generalized section:

Generafuzen Section of Loess.

3. Soll, black humus, changing below to brownish, no

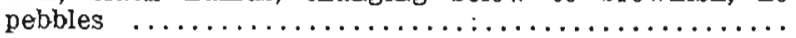

2. Loess, leached, buff to yellow, does not react to acid (dilute $\mathrm{HCl}$ ), no fossils or lime concretions in this

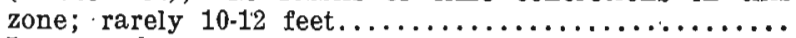

1. Loess, calcareous, upper few feet buff, grayish below, includes small shells and calcareous concretions in many places. This zone is usually not seen in exposures less than eight feet deep.

The persistence of these general characteristics in the region examined by the writers has an important significance in reading the history of the loess. Two things seem to be indicated by these phenomena: (1) That the color of the upper ten feet or more has been changed by oxidation from gray to buff or yellowish (and to brownish just below the soil); and (2) that percolating water has dissolved and removed the calcareous particles and snail shells from the upper six to eight feet or more, where they were present. If the calcareous zone is not exposed, fossil=shells may not be found.

The grayish loess has been regarded by some as a distinctly older deposit than the overlying buff loess. ${ }^{40}$ While this may be true of some of the gray or bluish gray loess described by Professor Shimek and others as occurring beneath the buff loess in places outside the Iowan drift area the writers have seen numerous exposures of buff loess grading downward into gray where the latter shows no particular evidence of greater age. In no case in the Iowan area have the writers noted any zone of leaching at the top of the gray loess and beneath calcareous buff loess, nor has such a definite, highly oxidized band been seen separating the two as Professor Shimek reports having seen in some places. The writers are inclined to regard the buff and the gray loess seen in most places in the northeastern quarter of the state as comprising respectively the oxidized and unoridized portions of one practically. continuous deposit. The general absence of shells and other calcareous material from the upper six to eight feet or more of Iowa, Vol. V, p. 366 . 
the loess, would seem to indicate either (1) that conditions during the time of deposition of this upper part of the loess were not favorable to local molluscan growth or (2) that the time since has been long enough for percolating waters to dissolve and remove the shells to the depths indicated, and that the deposition of this loess was in the main completed some time ago. So far as known to the writers there is no evidence warranting the first inference.

Leaching action would be accomplished by oxidation so that if the second deduction be correct it may. be inferred that the loess was largely unoxidized and gray or bluish gray in color when deposited. In those places where deposition of loess has continued to the present time it may be that some of the last of the transported dust was derived from the leached and oxidized portions of the drift and alluvial materials and so was oxidized and noncalcareous when deposited as loess.

The above phenomena also lead one to the inference that the main mass of the loess was once calcareous, that whereas now the leached zone is probably increasing in depth there was a time when calcareous loess accumulated at a rate greater than the rate of leaching. These inferences strongly suggest a sperial time of loess deposition, an epoch which may be considered as having practically closed when the rate of deposition became less than the rate of leaching. Since then there has probably been relatively little loess deposited in this region excepting locally in favored situations.

DISTRIBUTION OF THE LOESS.

The loess of the region under consideration is thickest in three situations: (1) along river valleys draining from the Iowan drift area; (2) around the border of the Iowan drift, and (3) in paha.

(1). In some places the buff loess and associated sand is so thick bordering the larger streams as to form hills and ridges rising distinctly above the adjacent interstream areas. This is so noticeable along Cedar river in Linn and Johnson counties and along Wapsipinicon river in Linn and Jones counties that one is reminded of the remark of earlier geologists, that the streams left the plains to cut through the hills. An exposure 
in a bluff in the northwest part of Cedar Rapids shows the unusual thickness of at least fifty feet of loess, and at the Chicago \& North Western Railway quarry southeast of that city there is at least thirty feet of loess overlying till and rock. . In some instances the loess in such situations is sandy.

Besides these cases of conspicuous topographic effects, there are many places along valleys where the loess is thick withont forming distinct ridges, and, in addition, sand dunes are to be found. The thickening of the loess along valleys is common both within and without the Iowan drift area, probably more so outside the marginal belt.

Just why the accumulation of loess should have been so marked along valleys is for the most part a question of source of supply and lodgment. It seems reasonable to refer the source of supply in large part at least to the river flats and the factors of lodgment to vegetation and topography. Northeastern Iowa was principally a prairie region at the time of settlement by white men, the timber being mostly confined to belts bordering the streams, ${ }^{41}$ and the thicker deposits of loess are found mostly in these timbered belts. There is no question but that the arboreal vegetation would favor deposition in these tracts. The same is true of the topography. Not only would the steep slopes and ravines cause lodgment, but furthermore the reduction of the velocity of air currents sweeping up over the bluffs from the valley bottoms would result in deposition in the lee of the crests.

(2) Another situation where the loess reaches considerable thickness is around the border of the Iowan drift area. It has been mentioned that the till within this area is generally at or near the surface, and that on crossing the border to the area of the Kansan drift the loess covering becomes notably thicker, even in locations not particularly related to valleys. As distance from the Iowan border increases the thickness of the loess on the Kansan diminishes, excepting where the loess is definitely associated with valleys. Over most of the Iowan drift area loess is in general either lacking or constitutes a very

\footnotetext{
tSiee map of primeval forests and swamps by W J McGee compiled principally from original records of the U S. General Land Office, U. S. Geol. Survey Eleventh Ana. Rept., PI. XXII, 1889-90. 
thin mantle rarely attaining a thickness of three feet, excepting in the southern and southwestern parts of the area, in Benton, Tama, and Grundy counties, where thicknesses of four to six feet are common. Reference is made elsewhere to this exceptional area.

As an excellent example of the areal relations of the loess to the Iowan drift, the North Liberty plain in the northern part of Johnson county may be cited. ${ }^{42}$

This plain, which is four to five miles wide and about eight miles long, appears to have been covered by an extension of $\mathbf{a}$ lobe of the Iowan ice across Iowa river. Its longer axis trends northwest-southeast. The drift here is covered by a thin mantle of wind-blown sand and loess but at the border these deposits thicken abruptly and form a prominent line of ridges and hillocks twenty to thirty feet high. As seen from the North Liberty plain this resembles a terminal moraine (Plate IX). Exposures and auger borings in this belt, however, reveal nothing but loess and sand. There may, perhaps, be a low core of drift, but positive evidence of such is wanting. As seen from the onter side, no immediate relief is discernible, the materials simply spread out over the Kansan drift surface and mantle the slopes of the adjacent valleys, that of Iowa river on the east and that of Clear creek on the south.

The ridges on the south and southwest sides of this plain are dominantly sand, but beyond these the texture of the material changes in a short distance to that of loess and the thickness of the deposit: is less. Cuts on the Interurban railway near the border of the plain which are twenty-five feet deep do not reach the bottom of the loess, whereas shallow road cuts five miles or less outside of this area expose the underlying Kansan till. These areal relations suggest that the materials of the bordering ridges were blown from the surface of the plain or from this and its westward continuation, the broad bottom of Iowa river valley in northeastern Iowa county.

Immediately, south of Blairstown, in southern Benton county, loess is thin or absent from the area having the Iowan type of

\footnotetext{
${ }^{2}$ Lelghton, M. M., Iowa Geological Survey, Vol. XXV, 1916. A full discussion of the evidences that the North Liberty plain is a part of the Iowan drift area is here glven.
} 
Iowa Geological Survey.

Prate IX.

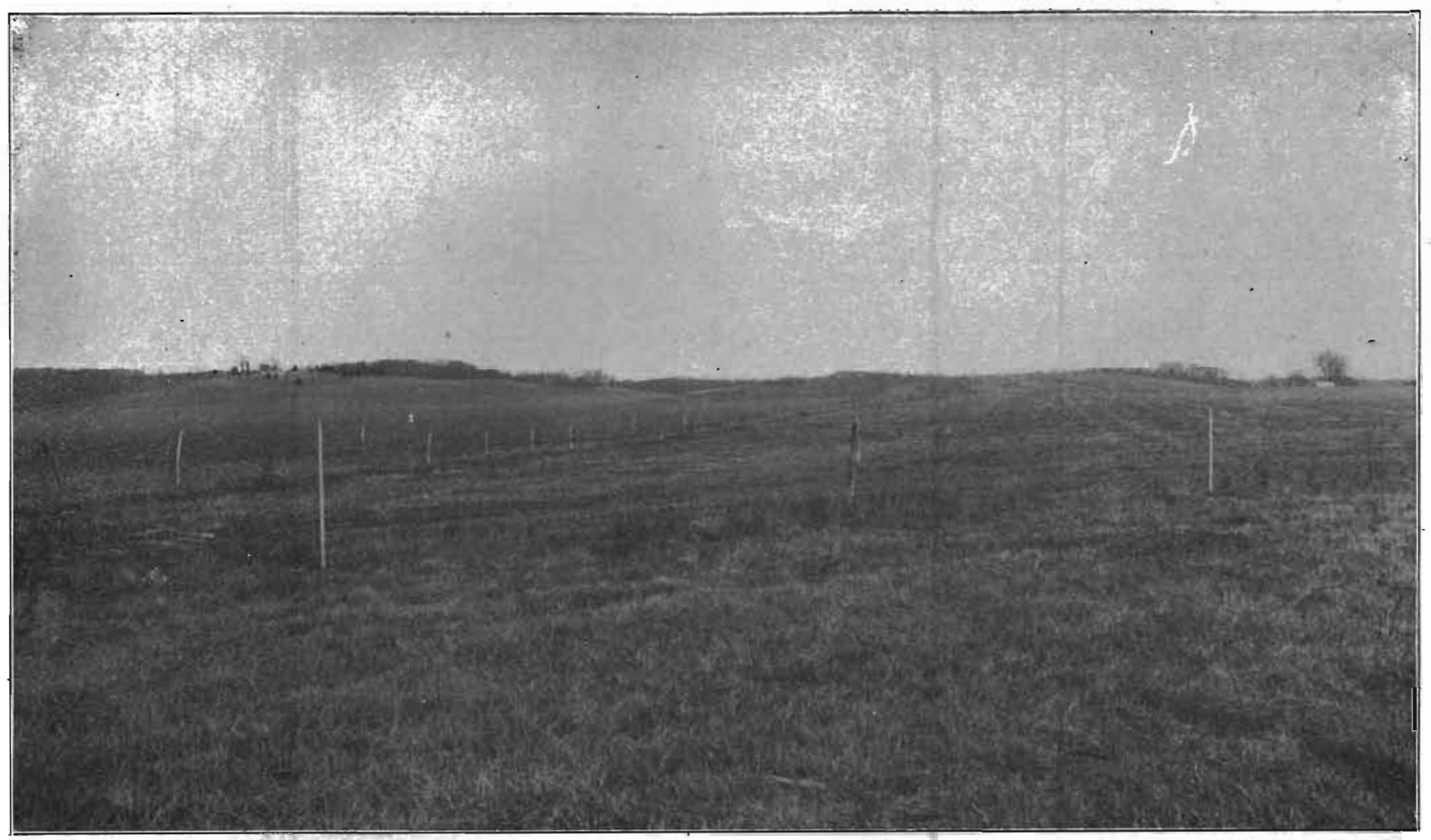

Loess hills and ridges bordering the North Liberty plain, Johnson County, Iowa. 

topography, but it thickens abruptly at the border of this area and mantles the rugged eroded surface of the Kansan drift beyond. If the loess came from Iowa river, five miles to the south, why should it thin so suddenly at the boundary of the area having the Iowan type of topography? Possibly because the drainage conditions of the dissected Kansan drift controlled the distribution of the timber and afforded conditions more suitable for anchorage of the loess than did the smoothly undulating prairie farther north. On the other hand the reason may be that the loess was blown southward from the raw surface of the newly deposited Iowan drift in the areas which continued as prairie. The winds may have been anticyclonic, blowing from the surface of the retreating ice sheet to the north and northwest.

Within that part of the northeast border of the Iowan drift area which extends from Fort Atkinson in southwestern Winneshiek county to Dyersville in western Dubuque county, the Iowan till is generally at or near the surface, but along the border the loess thickens into knolls and ridges. Throughout much of this distance there is clearly no genetic relation between the loess border and any streams. There is, however, a close general correspondence between this border and the line between prairie on the west and timber on the east, as shown by McGee's map. In other words, the thickening of the loess along this line is explainable on the ground that the forested surface of the dissected drift to the east afforded adequate anchorage for the wind-blown material but one must look elsewherè than to adjacent valley flats for the places of derivation of the dust by prevailing westerly winds. Professors Chamberlin and Salisbury, in their study of the Driftless Area, noted that this loess thins for a distance eastward and then thickens again in the immediate vicinity of Mississippi river. ${ }^{43}$ A corresponding change in texture is also said to take place, there being a sandy texture along the Iowan border, finer farther eastward, and then coarser again along the Mississippi. ${ }^{44}$ Professors Calvin, Leonard, Savage, Udden, and Bain in their reports on the counties east of and including the eastern border of the aU. S: Geol. Survey Sixth Ann. Rept., p. 283, 1884-1885.
HIbid, p. 281 . 
Iowan drift area ${ }^{45}$ refer to the thickened loess along this border as in contrast with the loess-free area to the west. Thicknesses are stated to range from a few inches to thirty feet. Professor Leonard states that the average thickness in Clayton county is not over ten feet, while Udden gives the average thickness on the Kansan drift in Clinton county as fifteen to twenty feet. All refer to it as probably, in large part at least, an accumulation of dust blown from the Iowan drift to the west.

These relations certainly strongly suggest that the loess. along the east border of the Iowan drift area from Winneshiek county to Dubuque county was derived from the surface of the Iowan drift. Here again anticyclonic winds from the retreating Iowan ice sheet may have been the transporting agent.

(3) Elliptical hills and elongated ridges of loess or capped with loess, which McGee called paha, ${ }^{46}$ are scattered over parts of the Iowan drift area, the large majority of them being concentrated in the southeastern part, in Benton, Linn, Johnson, and Jones counties. ${ }^{47} \mathrm{McGee}^{48}$ included in the type of topography represented by the paha "the elongated swell of soft and graceful contour, standing apart on the plain or else connected with its fellows sometimes in long lines, again in congeries, and locally merging to form broad loess plateaus" (Plate X). A few are situated in the Kansan drift area, but generally not far from the Iowan border. The paha of the Iowan drift area are situated on the uplands, and in most cases away from valley flats so that it is probable that in many cases the material comprising the mantle of the loess and sand was blown from the drift-plain itself.

One of the most notable characteristics of these hills and ridges is the prevalent northwest-southeast (south $45^{\circ}$ to $60^{\circ}$ east) trend of their longer axes.

Their persistent southeasterly trend suggests deposition of the loess by prevailing northwesterly winds, possibly anticyclonic winds blowing from the retreating ice sheet. There are, however, certain reasons for suggesting that, in some

\footnotetext{
sIowa Geol. Survey, Vols. IV, V, VIII, X, XIII, XV, XVI.

$46 \mathrm{H}^{2}$. ${ }^{47}$ See Stanwood, Fairfax, Rock Island, Cordova, Farley and Winthrop topographle sheets.

${ }^{48}$ Op. Cit., p. 397.
} 
instances at least, the direction of the wind was transverse rather than parallel to this trend, that is southwesterly, and that the trend itself is due to the orientation of drumloidal till cores.

Till was seen by the writers exposed up to thirty feet above the base of the eighty-foot north slope in the road cut on the paha ridge three miles northwest of Lowden, Cedar county. Above this level the cut, which was ten to fifteen feet deep, was wholly in loess to the top of the ridge.

Another hill, which would probably be classed as a paha, stands two miles north of Sand Spring, Delaware county. It is about one-half mile long, less than one-fourth mile wide, and its slopes rise sharply from the flat plain to a height of about fifty feet. Its long axis trends slightly south of east. A road cut at the crest of the ridge exposed seven feet of buff loess overlying four feet of leached till (apparently Kansan) with a wel]marked red ferretto zone at the top.

Professor Wm. H. Norton in his reports on the Geology of Linn, ${ }^{40}$ Scott, Cedar, and Bremer counties presented considerable evidence showing that some at least of these hills have cores of glacial till and he discusses the question of the nuclear till hills being genetically related to drumlins or other forms due to the moving ice. He cites the paha in Cedar county as found in three areas.

* * * an area peripheric to the Iowan frontier, in part within the Iowan drift, and in part situated on the Kansan overlooking the Iowan plains below, and an area npon the Kansan too remote from the Iowan border to have been under the control of the glacier ice of that invasion.

Although most of the paha are in the Iowan drift area and have been regarded by several writers as in some way related to the Iowan stage of glaciation they are not wholly confined to this area and as noted above the nuclei, in some cases at least, appear to be Kansan till.

Under the eolian hypothesis, drumlins of Kansan or Iowan drift, or of both, as well as other hills, would afford suitable

\footnotetext{
"Towa Geological Survey, Vol. IV, pp. 177-184, 1894; Vol. IX. 395, 1898; Vol. XI, pp. $356-366,1900$; Vol. XVI, pp. 376-386, 1905 . See also T. E. Savage's report on Benton county for description of till nuclei: Iowa Geological Survey, Vol. XV, pp. 141-143.
} 
-

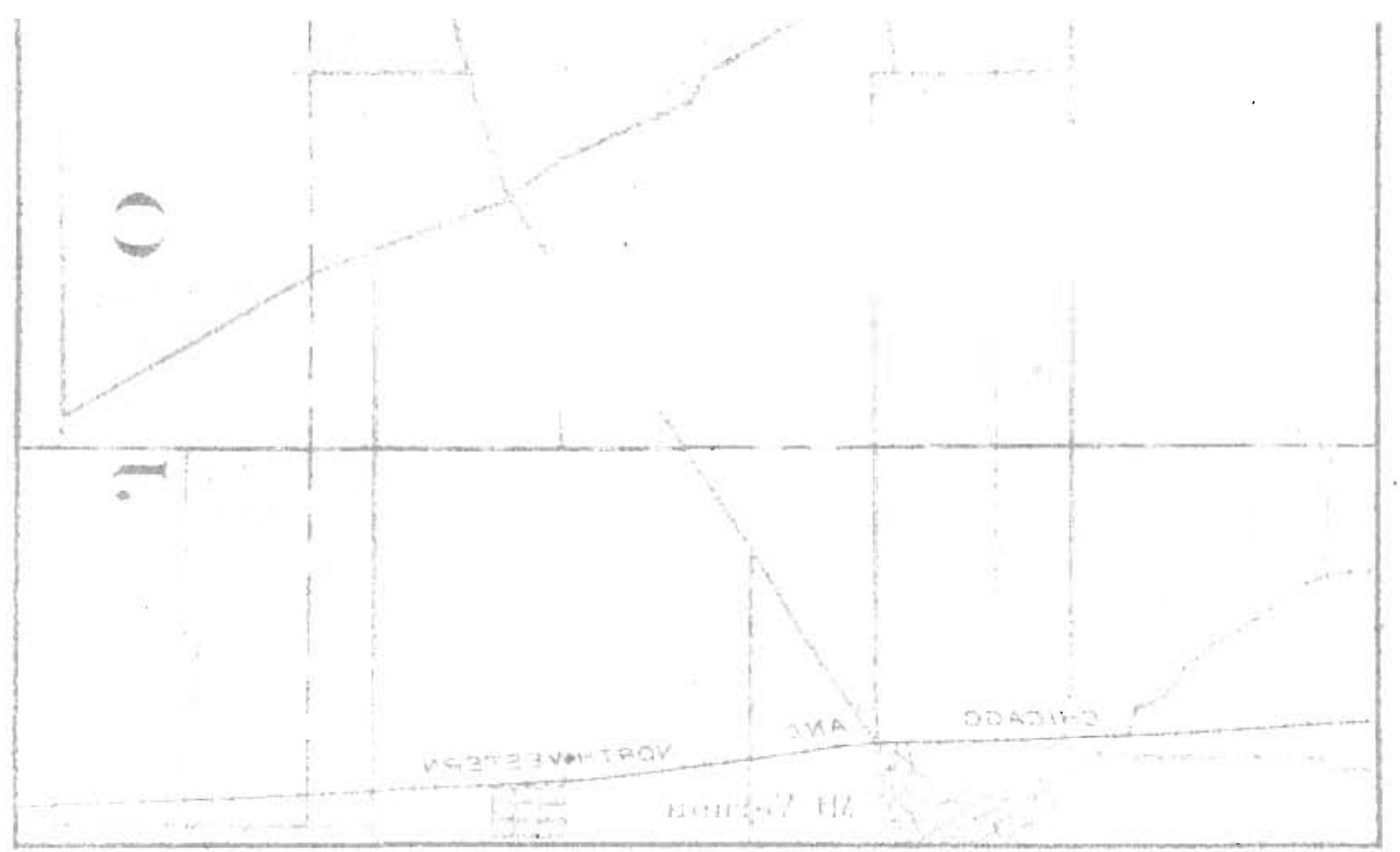

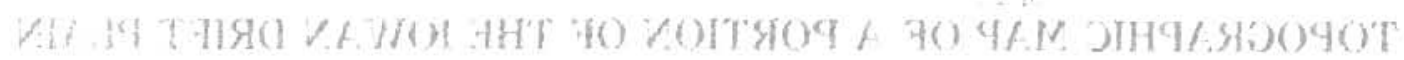

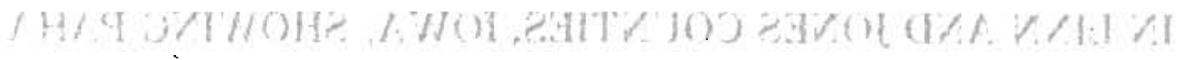


FROM U. S. G.S. TOPOGRAPHIC MAPS

IOWA GEOLOGICAL SURVEY (ANAMOSA AND MECHANICSVILLE SHEETS, IOWA) PLATE X

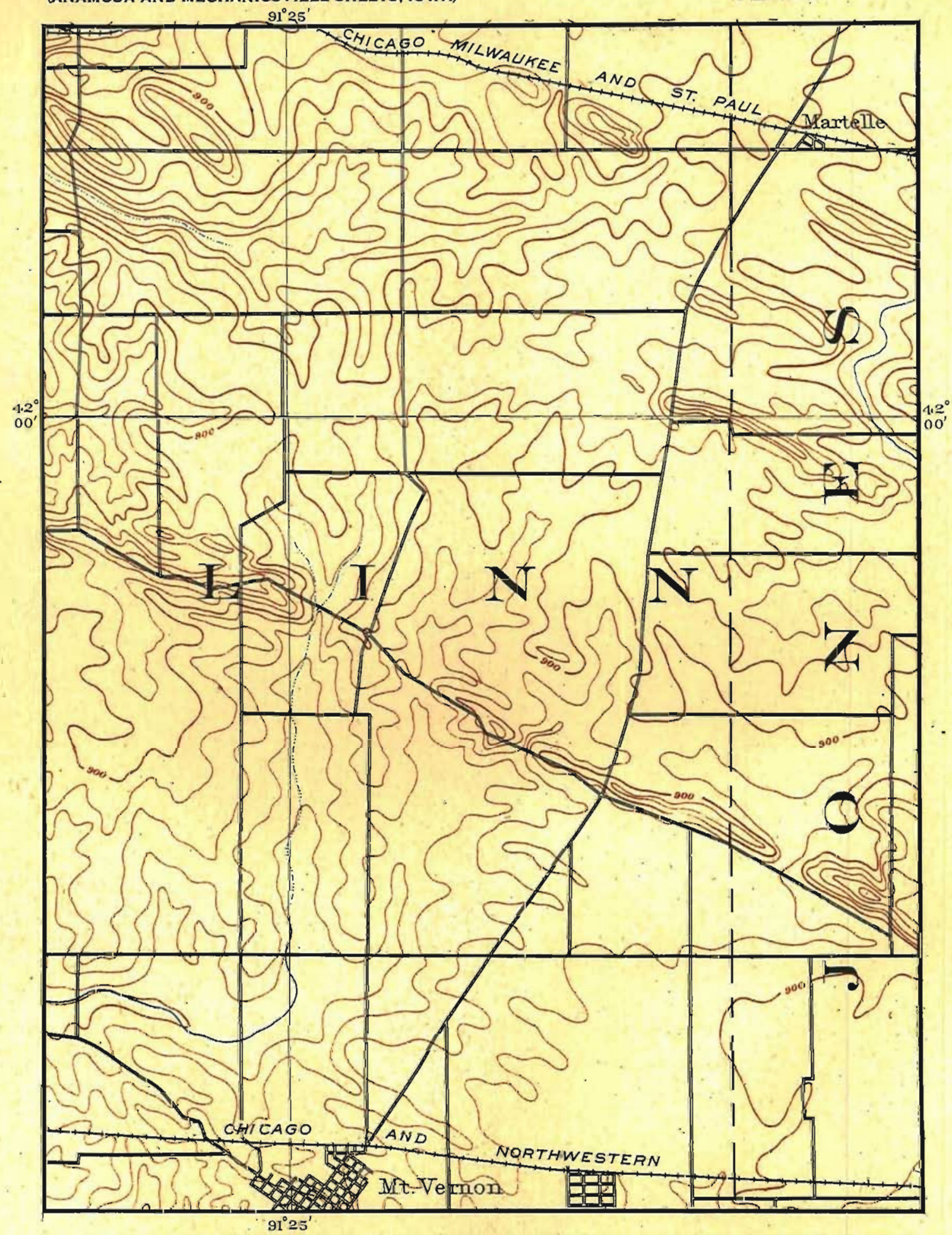

TOPOGRAPHIC MAP OF A PORTION OF THE IOWAN DRIFT PLAIN IN LINN AND JONES COUNTIES, IOWA, SHOWING PAHA

Scale $\overline{62,500}$

Contour Interval 20 feet

Datum is mean Sea Level. 
places for lodgment of wind-blown dust, both because of their own relief and because in many instances they were probably covered with timber. If the nuclei of the paha really are drumloidal the prevalent trend is explained as the long axes lie parallel to the known, or probable directions of the ice.movement. The thickness of the loess capping is in numerous cases fifteen or twenty feet or more.

Among the sections of paha examined by the writers were the cuts in the Norway paha described by Professor Savage ${ }^{80}$ where there seems clearly to be a till core to the ridge. The beautifully striated limestone bowlder pictured by McGee ${ }^{51}$ as from the loess of the Norway paha probably came originally from the till core of the ridge and was introduced into the loess by rolling or sliding down the hill slope while the loess was accumulating about it, though McGee did not so explain its presence. Writing of the foreign materials in the loess in this connection McGee states:

* * * Foreign materials are rarely found within it; in perhaps one in twenty of the sections commonly exposed in railway or roadway cuttings, cellar excavations, and roadside gullies, bowlder-like masses of drift clay, ranging from an inch to a foot or two in diameter, may be found; in one section in a hundred an erratic pebble (generally well rounded) may appear; in one section in five hundred a bowlder a foot or more in diameter may be found; and in one section of the many thousands examined a limestone bowlder, so beautifully striated as admirably to illustrate this class of icework, came to light.

Probably in most, if not all, cases the occurrence of pebbles or bowlders in the loess can be explained in a manner similar to that given above.

One relation of sand and loess to an included bowlder was very well illustrated in a cut on the interurban electric railway, one mile northwest of Bertram, Linn county, Iowa (Township 83 North, Range 6 West; north line of the northeast quarter of section 33) (figure 13). The section showed:

Nowa Geol. survey. Vol. XV. r. I42.

1U. S. Geol. Survey Eleventh Ann. Rept., Pl. XLVI. 


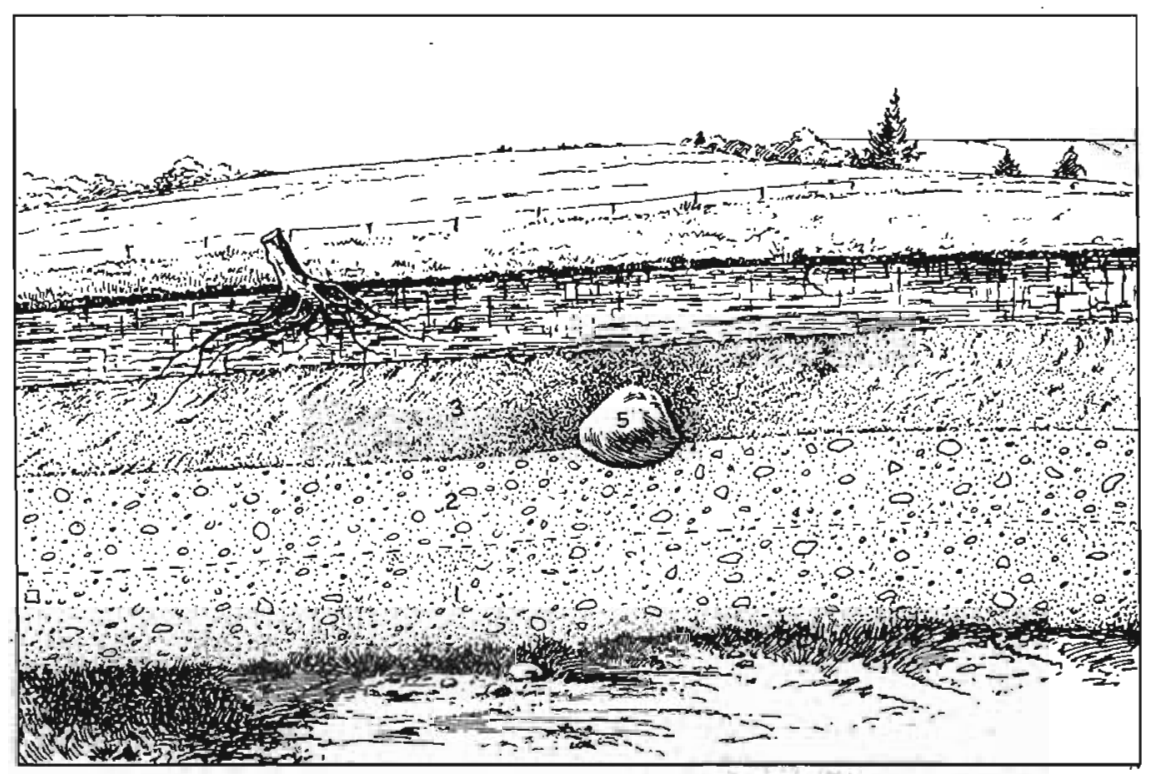

Fig. 13.-Diagram of drift exposed cn electric railway near Bertram, Iowa, showing relations of till (1 and 2$)$, wind-blown sand (3), and loess and soil (4),
to an included etched and polished bowlder (5).

DRIFT NORTHWEST OF BERTBAM.

4. Loess, buff-brown

Feet.

3. Alternating buff sand and brown clayey sand stratified, with cross-beds dipping eastward, wind-blown ........ 5

2. Till, sticky, brown, pebbly, noncalcareous clay.......... $3 \pm$

1. Till, dense, dark slate-colored, highly calcareous.........

Lying on the surface of the weathered till (No. 2) and embedded in No. 3 was a bowlder of coarse-grained red granite about three feet in diameter, whose sides and upper surface were etched and polished as by a sand blast. This sand was probably blown from the broad bottom of Cedar river about one mile to the southwest.

Conchusion as to the sources of the loess.-From the foregoing considerations it appears probable that the sources of supply of the loess in and adjacent to the Iowan drift area were in some cases the valley flats, in others the Iowan drift plain. The writers do not, however, extend this interpretation to the loess of southern and western Iowa and adjacent parts of Missouri, Kansas, and Nebraska, not wishing to express in this connection an opinion as to the sources of the loess of these more distant areas. 
STRATIGRAPHIC RELATIONS OF THE LOESS.

Relations to the Kansan drift.-In the Kansan area the loess mantles the slopes as well as the uplands, showing clearly that the Kansan drift-plain was dissected before the loess was deposited. There are also numerous sections which show this unconformity in another way; calcareous and fossiliferous loess overlies highly weathered Kansan drift. This is well shown by the relations in the cut near the west end of the interurban railway bridge west of Iowa City. Here approximately thirty feet of buff loess, leached of calcium carbonate to a depth of about ten feet, and calcareous and fossiliferous below, rests on nine feet of thoroughly leached, highly oxidized and partly decomposed Buchanan gravel, which lies in a sag on reddish leached Kansan till. The buff loess at its base grades into somewhat coarser, noncalcareous reddish material which may have been swept from the red soils of adjacent surfaces of Buchanan gravel or Kansan drift.

Widespread over the Kansan drift area south and east of the Iowan drift plain, a red soil or ferretto is found underlying the loess where these are exposed in many railroad and highway euts. In the new Chicago, Milwaukee \& St. Paul railway cuts near Melbourne in Marshall county, near Vining in Tama county, and east of Delmar Junction in Clinton county, the loess overlies the ferretto and the eroded surface of the Kansan drift.

Calcareous loess overlying noncalcareous super-Kansan "gumbo" has already been cited (See also Plate XI). The story told by this relation is the same as that read from the foregoing relations. In fact the evidence throughout the loesscovered Kansan drift area, from Marshall and Jasper counties on the west to Mississippi river on the east, and from Clinton county on the south to the Minnesota line on the north, shows that a long period of weathering and erosion intervened between the deposition of the Kansan till and that of the loess under consideration.

Relations to the Illinoian drift.-The loess is continuous across the Kansan drift to the Illinoian area in southeastern 
Iowa, and mantles the Illinoian drift. An examination of the deposit at many points in Scott, Muscatine, Louisa and Des Moines counties shows it to have practically the same constitution and amount of modification by weathering as the loess farther north.

Cuts on the Davenport and Muscatine interurban railroad through upland divides four miles west of Davenport, expose twelve to twenty feet of buff loess, leached to depths of seven or eight feet, and calcareous and fossiliferous below. There is a mantle of loess even on the flat upland which generally is thicker than the eight-foot auger could penetrate. In most places it is leached at least eight feet, but in one or two instances calcareous loess was struck at six to seven feet. In a few other places northeast and northwest of Davenport, the thickness of noncalcareous loess noted ranged from five to eighteen feet. In the area west of Muscatine, buff loess, with a leached zone similar to that of the loess immediately bordering the Iowan drift area, mantles the Mlinoian drift to depths of more than eight feet. The same is true about Wapello, and also west and north of Burlington, excepting that in the latter locality the loess is slightly thinner. Here no thicknesses greater than five to seven feet were noted, and in most cases it is leached throughout its entire thickness.

Examinations of the loess by Mr. Alden in the Mlinoian drift area, in parts of Rock Island, Henry, McDonough, and Fulton counties, Illinois, showed the prevalence-of similar characteristics as to thickness, composition, fossil content, and amount of modification by weathering. This deposit is continuous eastward to and across Illinois river where, as shown by $\mathrm{Mr}$. Leverett, $^{52}$ it passes under the early Wisconsin drift in the region of Peoria. ${ }^{53}$

While the loess lying on the Illinioan till is apparently of the same age as that overlapping the Iowan drift, it seems clear that the Illinoian till suffered much more modification by weathering and erosion prior to the deposition of the loess than did the Iowan drift. This is discussed in the following chapter.

\footnotetext{
s2Illinois glacial lobe, U. S. Geol. Survey Monor 38, p. 187, 1899.

s In places along the Mississippl bluffs there was observed light gray to light buff loess which is leached to a depth of but two to four feet. This may be the product of later eolian deposition, continuing to the present.
} 
Relations to the Iowan drift.-In the area of the Iowan drift the loess is generally so thin that the leached zone extends down into the till. None of the exposures or borings revealed calcareous loess overlying leached till. On the other hand, at least one section, in an interurban railroad cut near Lisbon, Linn county, exposed calcareous till immediately beneath calcareous loess and sand. The relations noted at this place were as follows :

Drift West of Lisbon, Iowa.

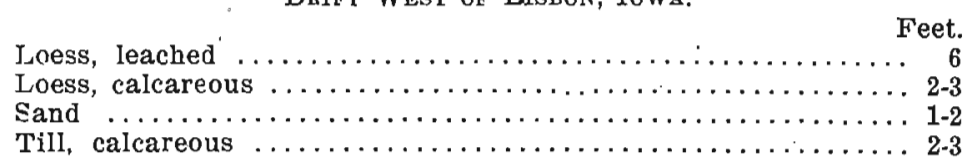

Relations similar to these were found by making borings in the southwestern part of the Iowan drift area, in Benton, Tama, and Grundy counties. The loess in this latter territory is thicker than in the rest of the Iowan area, and lies as a general mantle with an average thickness of four to six feet. In penetrating this again and again with the auger, it was found that the loess was wholly leached but that the till beneath was rarely leached more than a few inches to one and one-half feet. In other words, where the covering of loess on the Iowan drift is thicker the leaching of the till is less. This strongly suggests that the leaching process has but recently reached the till. The absence of any deeper color due to oxidation of the upper part of the till as compared with the color of the overlying loess is of like significance. It indicates that the Iowan till suffered but little modification by weathering before the loess was deposited upon it. There is generally at the top of the till and beneath the loess, as seen in cuts, a more or less definite line of pebbles. This is probably the residual coarse material left from the slight wind erosion and rain wash which occurred at those particular places before the till was protected by the loess.

In line with the foregoing evidences is the fact that no soil was seen between the loess and the underlying till in the area of the Iowan drift such as was observed in the Illinoian drift area in the vicinity of Wapello and Burlington. Moreover, the Iowan till, where not loess-covered, is leached to somewhat less 
depths than the average sections of loess in the bordering Kansan drift area. This is in harmony with the textures of the two formations. Since the loess is more porous than the till, it should show a greater depth of leaching if both are of approximately the same age.

All these considerations of the character and relations of the loess lead to the conclusion (1) that a very long time intervened between the disappearance of the Kansan ice sheet and the deposition of the main sheet of loess under discussion, (2) that there was also a considerable interval after the Illinoian ice melted away before the Illinoian drift became mantled with loess, and (3) that on the contrary, the deposition of this loess followed almost immediately the recession of the front of the glacier which laid down the Iowan drift.

This conclusion may at first seem incompatible with the presence of the fossil shells which, according to Professor Shimek, are like those species of snails which live in the same region today and feed upon vegetation. It should be recognized, however, that the climate at the close of a glacial epoch is probably different from that at the beginning. The formation and extension of a glacier is a consequence of glacial conditions having prevailed for some time. Its development and advance are preceded first by a change to glacial temperatures and a vast accumulation of snow. The retreat of the ice front, on the other hand, occurs only when the interglacial climate has become well established: Probably a zone adjacent to the retreating front of a continental ice sheet is affected by cold winds blowing from its surface and somewhat by the presence of the ice itself, but the conditions are less. severe than in the case of an advancing ice sheet. In the former case, the climate opposes the existence of the ice, while in the latter, it is responsible for it. Although present temperatures probably did not prevail in the immediate vicinity of the Iowan ice, it seems likely that after the climate had so changed that the ice had melted back hundreds of milés from its extreme. limit, seasons approximating those of the present may have prevailed over those areas where the loess now occurs. The length of time consumed in a retreat of even a thousand 
miles would be brief geologically, and probably would not have resulted in any conslerable amount of weathering of the new drift. The statement, therefore, seems sound, that the main sheet of loess under consideration was deposited immediately following the Iowan stage of glaciation. It is therefore a near-correlative of the Iowan drift, though it really represents the early part of the Peorian stage of deglaciation.

Relations to the Wisconsin drift.-If the conclusion is sound that most of the loess in and adjacent to the Iowan area was deposited immediately following the Iowan stage of glaciation, the main deposit of loess should be found extending beneath the Wisconsin drift.

No sections were observed by the writers in Worth, Cerro Gordo or Franklin eounties showing either the Iowan drift or the overlying loess extending westward under the late Wisconsin drift of the Des Moines lobe. Neither have such exposures been reported by the Iowa Geological Survey. No thorough search for such was made by the present writers nor was there any extended examination of the Wisconsin drift. A few short trips were made across the border in the last three of the counties named. In most of the places seen there was no loess on the Wisconsin drift. In a few places in Franklin a thin coating of loess or loesslike loam was found on the marginal slope of the Wisconsin drift while thicknesses of one to ten feet were found quite generally on the Iowan drift to the east. At one point six miles southwest of Ackley, Hardin county (near middle of south one-half of Aetna township, Township 89 North, Range 19 West), in the area of the Wisconsin drift, a boring was made which penetrated leached loess four and one-half feet and calcareous loess three and one-half feet without reaching the underlying till. This is probably a rather exceptional deposit blown up from Iowa river about one mile distant. On the Iowan drift plain to the east thicknesses of one to eight feet were observed, the lower part being calcareous where the thickness was greater than four to four and one-half feet.

These are, of course, not the first observations of slight local deposits of loess overlying Wisconsin drift. ${ }^{54}$ Similar occur-

Mallabury, R. D., Loess in the Wisconsin arift formation. Jour. Geology, Vol. 4, pp. $929-938,1896$. 
Lowa Geological Survey.

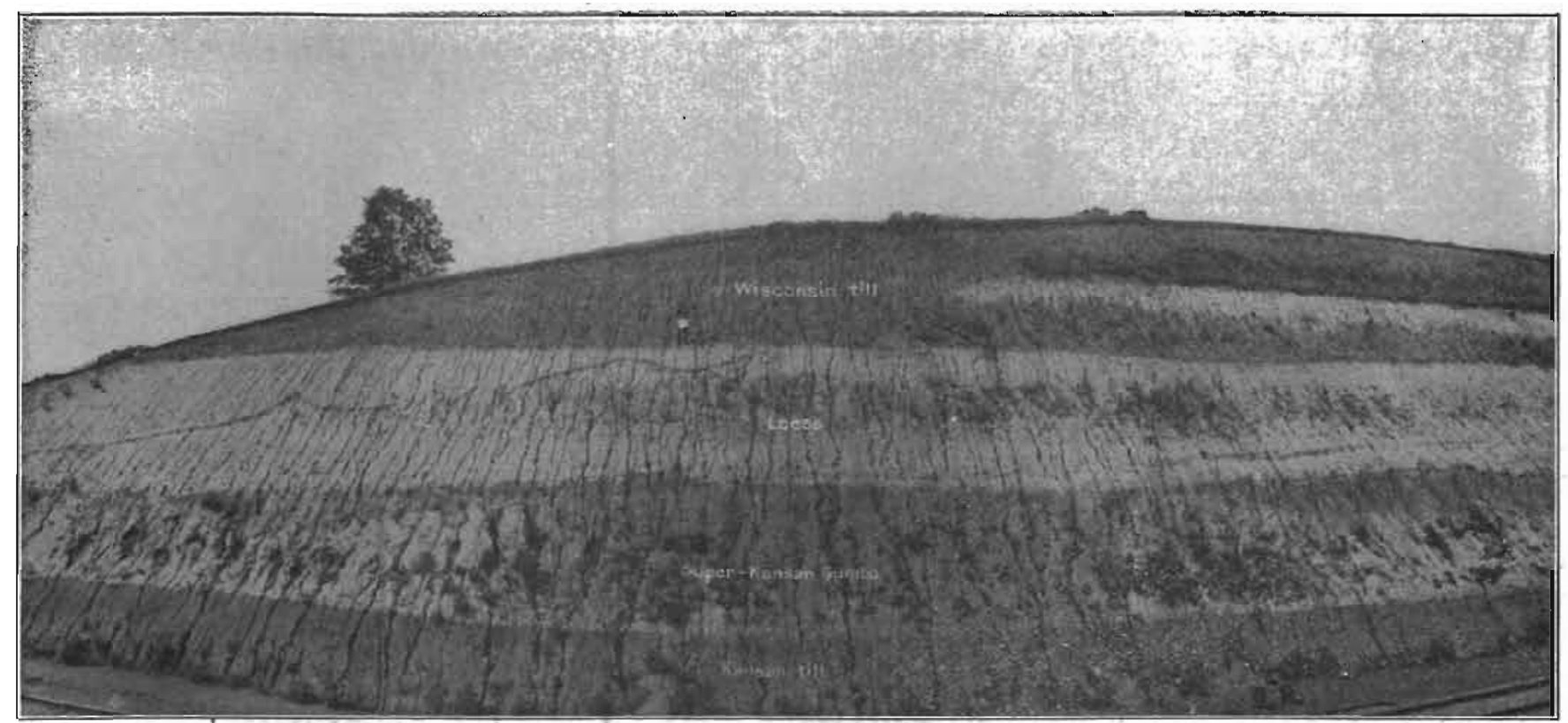
View of drift exposed in Chicago, Milwaukee \& Bt. Paul railway cut southwest of Rhodes, Iowa, showing Kansañ till (1); super-

Ptate XI.

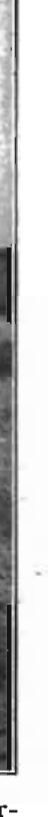




\section{,}


rences have been noted by Mr. Leverett at various places in Illinois ${ }^{85}$ and by Mr. Alden at various places in southern Wisconsin and in Bureau County, Illinois.

Shimek has described post-Wisconsin loess also and has shown that some loess deposition has continued to the present time and is yet going on. These deposits of known Wisconsin or post-Wisconsin age should not, however, lead to confusion of the discussion in hand, which is that the loess formerly called "Iowan" but deposited during the Peorian stage of deglaciation, extends beneath the Wisconsin drift.

In southeastern Hardin county and in Marshall county the Iowan drift does not extend westward to the Wisconsin drift boundary but the loess is continuous across the interval and passes beneath the later drift. In his report on the geology of Hardin county ${ }^{56}$ Prof. S. W. Beyer wrote as follows :

Outcrops of the loess may be observed well across Providence township, and the loess undoubtedly continues under the Wisconsin drift and connects with the deposits near Ames in Story county. On the southeast quarter of section 6 in Providence township the loess appears in a cut along the roadway overlain by twenty feet of Wisconsin drift and resting upon the oxidized Kansan. Also in section 16, in a road cut, eight feet of loess is visible. The deposits at these exposures are closely set with root casts, some of which measure four inches in diameter. Loess concretions are numerous and a few gasteropod shells were noted, the most common being a species of Succinea.

At a point about twenty-seven miles south of the Hardin county exposure, the writers found similar relations exhibited by a cut on the Chicago, Milwaukee \& St. Paul railway in the northwest quarter of section 19, Eden township (Township 82 North, Range 20 West), Marshall county. At this place, which is about three miles southwest of Rhodes, the railway climbs from the dissected area of the Kansan drift to the Wisconsin drift plain. The big cut at the county line (Plate XI) showed the following section:

\footnotetext{
sLeverett, F., The Illinois glacial lobe, U. S. Geol. Survey Mon, 38, pp. 267-268, 1899.

Bseyer, S. W., Geology of Hardin County: Iowa Geol. Survey, Vol, X, p. 282, 1899.
} 
Drift is Chicago, Muwatge: \& St. Paul Rarlwat Cut Trmet Milfs Southwhes of Rhodes, Iowa.

Feet.

4. Till, Wisconsin, leached three feet, calcareous below..... 25

3. Loess, mostly buff, gray at bottom, leached four or five feet in one place, snail shells in calcareous portion...... 25

2. "Gumbo," noncalcareous gray clay, similar to that found elsewhere on the Kansan drift, contains $\approx$ mall pebbles... 8-10

1. Till, probably Kansan, brownish buff, contains rotten granites, leached 9.10 feet, calcareous below; exposed..... 5-12

An irregular ferruginous line or shell two to three inches thick extends obliquely through part of the loess and ends at the base of the Wisconsin till as though cut off.

Here it is clear that the loess was deposited not only before the late Wisconsin ice invasion, but at a time separated therefrom by an interval of leaching and oxidation (the Peorian interglacial stage of Leverett).

As noted above (page 155) Mr. Leverett has shown that the loess also extends eastward beneath the early Wisconsin drift in the region of Peoria, Illinois.

SUMMARY OF THE RELATIONS OF THE LOESS.

1. The loess in and about the Iowan drift area is believed to be mostly wind-blown material.

2. The sources of supply were in some cases the surface of the Iowan drift, in otluers the valley flats both within and outside of the Iowan area.

3. It is probable that this loess was, for the most part, originally calcareous.

4. If it was originally calcareous, that part which was blown from the surface of the Iowan drift must have been derived before the drift was leached. This is one reason for regarding its age as immediately post-Iowan or, in other words, early Peorian. This is in agreement with the evidence showing that the Iowan drift was but little eroded or modified by weathering prior to the deposition of the loess.

5. The Kansan drift area was probably already clothed with vegetation when the accumulation of this loess began, as is inclicated by the presence of herbivorous land-snails in the loess. The change from a glacial to an interglacial climate, which had already initiated the retreat of the Iowan ice front made such 
vegetation possible. This vegetation, especially the arboreal, was a factor in affording lodgment for the loess, as was also the rough topography of the Kansan.

6. The recently exposed surface of the Iowan drift undoubtedly had some vegetation soon after the melting of the ice, but it was probably sparse. There is nothing to show that arboreal vegetation ever gained much of a foothold in the Towan drift area excepting in the rougher parts and in narrow belts along the streams.

7. The broad prairies, when they were dry and where they were not effectively protected by prairie grasses, were undoubtedly sources for clouds of dust and sand, just as the ploughed fields of man and his unpaved highways have been since his appearance.

8. The till nuclei of the paha rising above the surrounding plain were well drained and favored the growth of arboreal vegetation and thus afforded increased lodgment for eolian materials.

9. In order that the loess could have accumulated as a calcareous deposit, the rate of deposition must have exceeded the rate at which the calcium carbonate was removed by leaching. It is therefore perhaps not incorrect to say that there was a special time of deposition for the loess which borders and overlaps the Iowan drift. This is particularly so since there was time for considerable leaching and oxidation of that part of this' loess which now underlies Wisconsin till before that later till was deposited.

10. The time of main loess deposition probably did not end abruptly, but as vegetation more completely covered the drift, the amount of material blown about by the winds gradually diminished.

11. Although the time of main loess deposition is thought to have been short, geologically speaking, it is probable that the rate of accumulation of the loess even during that time was sufficiently slow for successive generations of plants to decay before the vegetable matter was buried to such depths as to be preserved. 
CONCLUSIONS FROM THE RELATIONS OF THE LOESS.

The general conclusions from this study of the loess are those stated above (page 157); (1) that the deposition of the uppermost till of the Iowan drift area occurred but a short time prior to the acclimulation of the main sheet of loess which borders and overlaps it; (2) that the Illinoian till was deposited at a time considerably before this epoch of loess deposition, and (3) that the Kansan drift was deposited considerably earlier than the Illinoian till and much earlier than the loess was formed, or in other words, this line of evidence also supports the view that the Iowan stage of glaciation was distinct from, and later than, either the Kansan or Illinoian stages of glaciation.

\section{CHAPTER VIII}

\section{THE AGE OF THE IOWAN DRIFT.}

Considerable evidence has already been presented tending to show that the Iowan drift is distinct from and younger than the Kansan drift. The amount of modification of the drift by weathering and the stratigraphic relations of the main deposit of loess show clearly that the Iowan drift is also distinct from and older than the Wisconsin drift. The Iowan drift is not now known to extend into the area covered by the Illinoian ice sheet nor to overlap the Illinoian drift, so that their mutual age relations can not be determined directly but must be inferred from comparison of the relative amounts of their modification by weathering and erosion and by their relations to the main deposit of loess. Reference has been made to these relations in the preceding chapters and the characteristics of the Iowan drift have been discussed at length. The Illinoian drift has been treated by Mr. Leverett in his monograph. ${ }^{57}$ Some further consideration may be given to it in this connection.

In southeastern Iowa and in that part of western Illinois south of Rock river which was examined by Mr. Alden, the Illinoian drift area has a fairly uniform type of topography. The striking features are the broad upland areas (in many places

\footnotetext{
${ }^{57}$ Leverett, Frank, The Illinois glaclal lobe: U. S. Geol. Survey Mon. 38, 1899.
} 
Iowa Geological Survey.

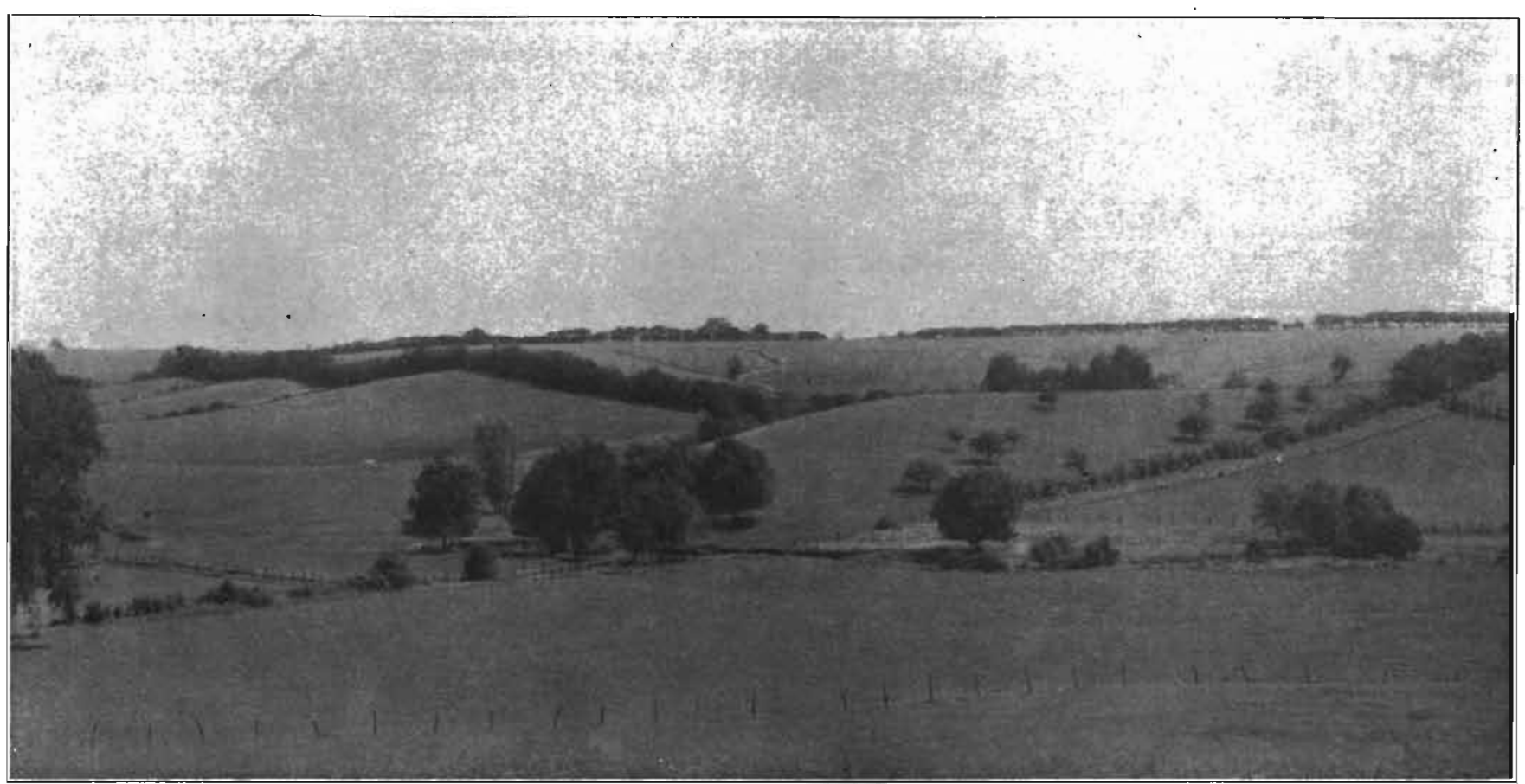

View of eroded Illinoian drift plaln in Rock Island County, Illinois.
PiATE XII

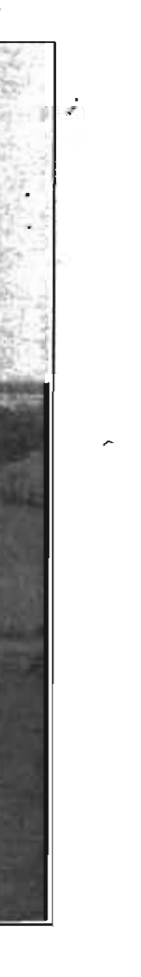



four to five miles wide) and the sharply incised valleys (Plate XII). The uplands are nearly flat, and comprise relatively much more area than do the remnants of the Kansan upland in Iowa (Plate I). The larger valleys average 100 to 150 feet in depth, and have valley flats one-half to one mile, or rarely two miles wide. Branching tributaries have partly dissected the bordering uplands, but on the whole they are short (Plate XIII). The broad, flat upland tracts with the sharply-cut valleys intervening, give the impression that the Illinoian ice on melting left a nearly flat drift plain. Since then sufficient dissection has taken place to develop drainage systems to a stage of late youth.

As compared with the Iowan drift topography (Plate II) the Illinoian shows considerably more erosion. In some parts of the Illinoian drift area this may be due partly to proximity to Mississippi river, which has resulted in fairly high gradients. ${ }^{58}$ But on the other hand, the original surface of the Illinoian drift probably was nearly flat, whereas the surface of the Iowan drift originally had gentle slopes, with inherited major drainage lines. The latter condition is thought to be as favorable to the development of a drainage system as the former, if not more so; and, hence, the greater amount of erosion of the Illinoian drift appears to indicate a longer time of exposure. ${ }^{59}$

The weathering of the upper part of the Illinoian till was due to its exposure prior to the deposition of the loess. The oxidized zone is not generally cut off by the erosional slopes as is the ferretto at the top of the Kansan but it extends well down below the upland where the slopes are not too steep. The loess also mantles the slopes at least part way down where these are steep, and entirely to the bottom where they are not so steep. Most of the erosion and oxidation of the Illinoian till thus appears to have been accomplished prior to the deposition of the loess.

\footnotetext{
ss See. Milan and Edgington topographic maps. for a distance of 80 to 100 miles southwestward from northern Knox county, Illinois, and the reging of and the region of Galesburg. the watershed between Mississte thancock county the divida is in closer the major than the minor stream. In northern Hancock county the dive east flows fifty miles or more to Illinois river. The topography of this part of the Illinoian area is well illustrated by the Colchester, Macomb, Avon, and Canton topographic area is well illustrated by the colchester, drift area has not had much advantage maps. Certainly this part of the Illinolan drift area has not had much advantage Illinois river may have affected it.
} 
There seems to have been comparatively little erosion since the loess was laid down.

Near Davenport, Iowa, in the cuts above referred to, the loess. lies on slopes of erosion of the Mlinoian and older tills, and the calcareous and fossiliferous portion of the loess rests on till oxidized to a brownish tint and leached to depths of about six feet. In the vicinity of Wapello, Iowa, there are exposures showing a buried soil separating the loess from till, and in some places a "gumbo"-like clay is found at this horizon. In Grandview township (Township 75 North, Range 3 West) south line of the southeast quarter of section 33, there was exposed in both sides of a ravine the following:

Deposits Four axd Cxe-Helf Mules Norter of Wapello, Iowa.

Feet.

2. Loess, buff, rusty at bottom................ 12

1. Silt, almost black like soil at top, dark drab below, "gumbo"-like in texture, with scattered small pebbles and sand grains, noncalcareous................. 6

In Port Louisa township (Township 74 North, Range 3 West), north-central part of section 10, a road cut on a valley slope showed:

Deposiț Thiee and ONe.filf Mnes Nobth of Wapexlo, Iowa.

Feet.

2. Loess, buff, rusty at bottom.................. 10

1. Soil (contact sharp), exposed................. I

At neither of these places was the underlying till exposed.

Some of the more deeply weathered till exposed in these counties, especially in cuts well below the upland level, may be Kansan. At these places the Illinoian till is absent beneath the loess, apparently as the result of preloess erosion, and if the weathered zone is absent, it is not always possible without careful examination to determine whether the till exposed is Kansan or Mlinoian. Where moderately weathered till is exposed at the higher levels the presumption is that it is Illinoian. Professor Udden found a lithologic difference between the Kansan and Illinoian till of this region but the writers made no such careful' comparison.

In 1905, Mr. Alden examined an exposure in Wapello township, (Township 74 North, Range 3 West, northwest quarter of 
FROM U. S. G. S. TOPOGRAPHIC MAPS

IOWA GEOLOGICAL SURVEY PLATE XIII

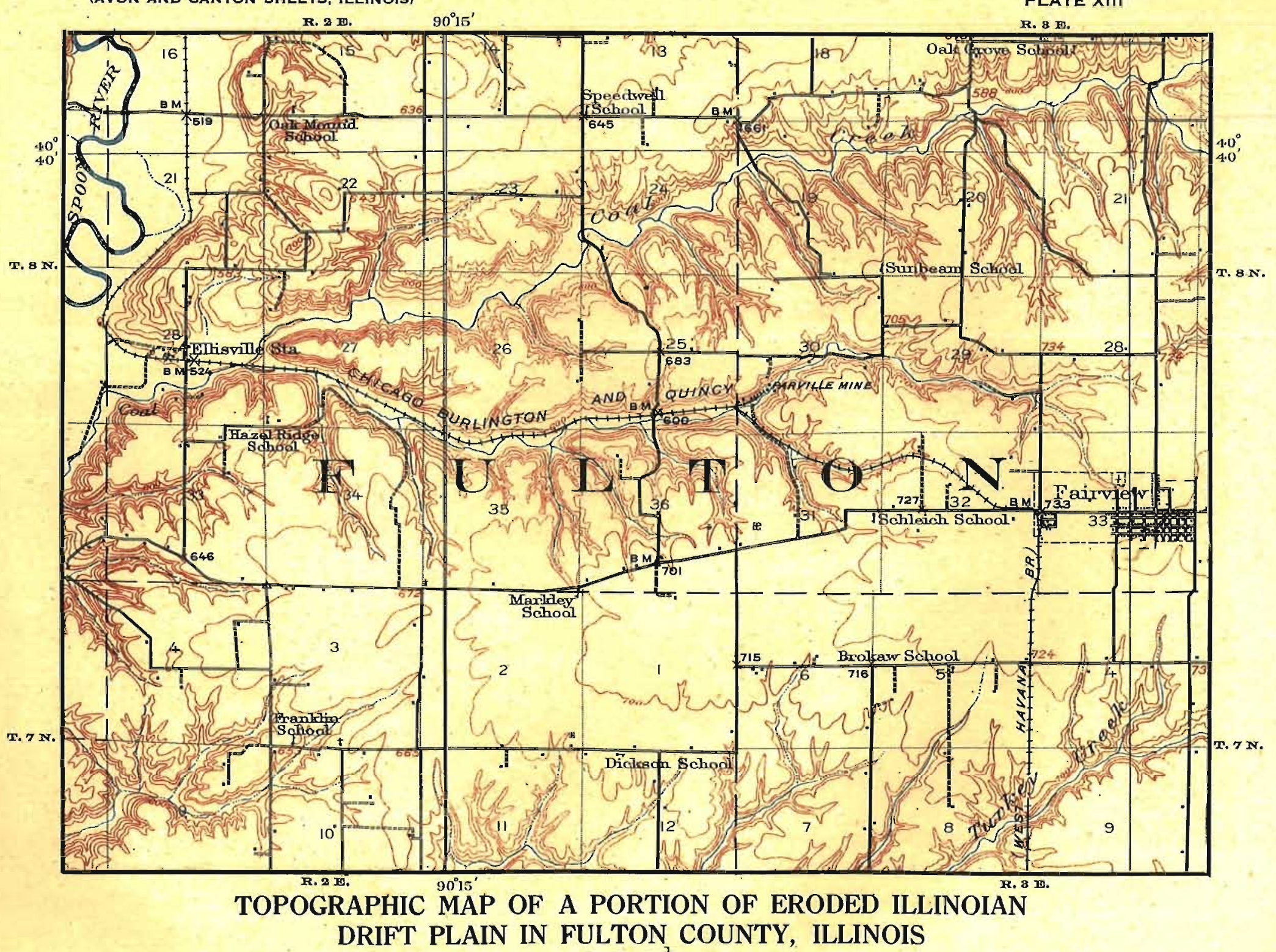
DRIFT PLAIN IN FULTON COUNTY, ILLINOIS

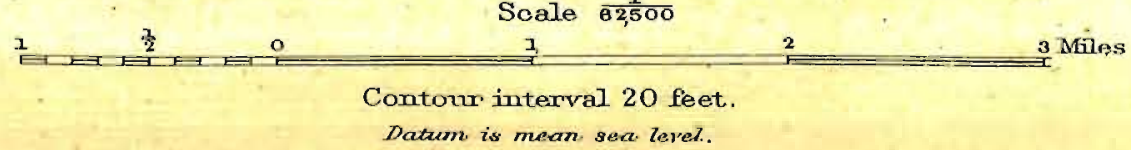



section 15), in the face of the bluff east of the north end of the Iowa river bridge. When seen in 1914 the section was badly obscured by slumping but peat and soil could still be seen beneath twenty-five feet of loess and sand. The section when seen in 1905 showed the following deposits:

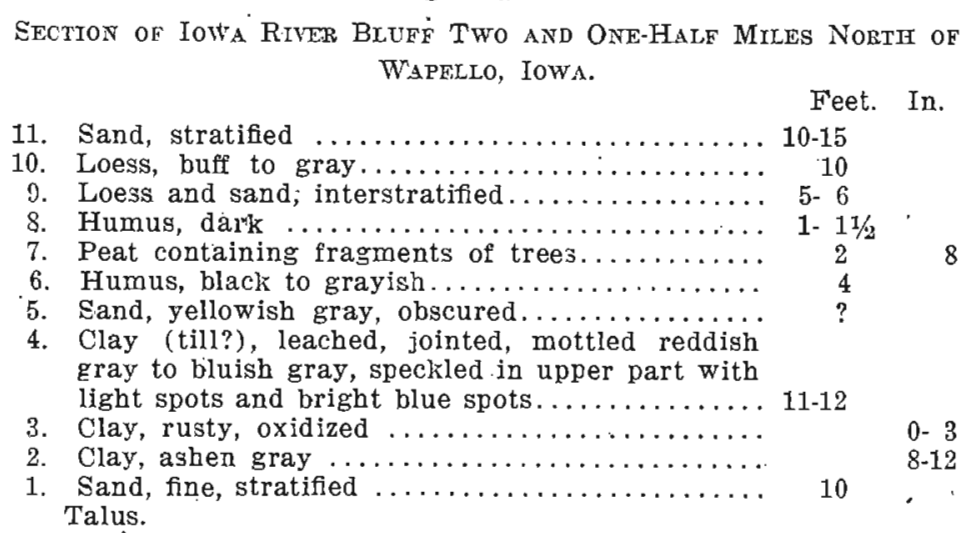

Udden describes the Sangamon soil, which separates the Mlinoian till from the overlying loess, as well developed at many places in Louisa county. The peaty phase is said to be most pronounced in the east bluffs along Iowa river northeast of Wapello.

North of Burlington, soil and gray "gumbo" were seen beneath the loess in Burlington township (Township 70 North, Range 2 West), west line of section 4; in Franklin township (Township 71 North, Range 3 West), southeast quarter of section 13; and in Yellow Springs township (Township 72 North, Range 3 West), central part of section 32 . Borings made by the writers on the flat upland near the south line of section 2, Franklin township, and in Flint River township (Township 70 North, Range 3 West) at the middle of the north line of section 2, revealed a black soil beneath about seven feet of loess. In the former place the lower three and one-half feet of the loess was gray and calcareous. In this county, as in the others, the loess mantles the slopes as well as the uplands.

Doctor Kay"o states that "after a somewhat careful study of the gumbo which lies on the Illinoian drift in southeastern Iowa,

\footnotetext{
${ }^{\infty} \mathrm{Kay}, \mathrm{Geo}$. F., Gumbotil, a new term in Pleistocene geology: Science, new ser, Vol. XITV, pp. $637-638,1916$.
} 
and which was discussed by Leverett in Monograph XXXVIII of the United States Geological Survey, pages 28 to 33, the conclusion has been reached that here, also, the gumbo is so related to the drift that it is undoubtedly the thoroughly'weathered product of the Illinoian drift."

Mr. Leverett has discussed the Sangamon soil and weathered zone as developed in Illinois. ${ }^{62}$ He describes one extensive exposure of the soil as found at the Brick and Tile Works in Galva (Henry county). Here fifteen feet of loess is underlain by one foot of black mucky soil in which was embedded a log one foot in diameter. Beneath this was the Illinoian till.

Mr. Alden also observed the loess in similar relations to the weathered and eroded drift in that part of Mlinois lying south of the big bend of Mississippi river and the Green river basin, although only slight traces of black soil were noted by him at the Sangamon horizon.

From these various observations it is evident tliat the Illinoian drift has been modified much more by weathering and erosion than has the Iowan. It also appears that most of the modification of the Illinoian occurred prior to the formation of the main deposit of loess. It seems clear therefore that the Iowan drift is entirely distinct from and considerably younger than the Illinoian drift. At the Illinoian stage of glaciation the Labrador ice sheet extended to and across Mississippi river in southeastern Iowa. The relations of the Keewatin glacier at that time are not known. During the Sangamon stage of deglaciation the Illinoian drift was considerably eroded, its upper part was leached and oxidized, soil and vegetable deposits were formed and, in places, a super-Illinoian "gumbo" was developed. This was followed by the extension of an ice sheet from the Hudson Bay region southward into northeastern Iowa and the deposition of the Iowan drift. The relations of the Labrador glacier at this stage are not now known. Accompanying and following the melting of the Iowan ice prevailing conditions resulted in the accumulation of the main deposit of loess. This represents the early part of the Peorian stage of deglaciation. During the later part of this stage the Peorian soil and weath"Leverett, $F$. . The Illinois glacial lobe: U. S. Geol. Survey Mon. 38, pp. 125-130.
1899 . 
ered zone was developed and the loess and Iowan till were subjected to some erosion, leaching and oxidation. This stage of deglaciation was followed by an extension of the ice from both the Labrador and Keewatin centers, that from the latter overriding the Iowan drift excepting in northeastern Iowa and, perhaps, in southeastern Minnesota and some areas farther west. At one of the oscillations of the Keewatin ice sheet of the Wisconsin stage the Des Moines lobe occupied north-central Iowa. On its melting the Recent epoch was inaugurated. The consideration of the various lines of evidence reviewed in this paper leads the writers to the conclusion stated in the Introduction, that there is warrant for the continued use of Iowan drift and Iowan stage of glaciation as major subdivisions of the Pleistocene classification.

\section{CHAPTER IX}

\section{BORDER PHENOMENA AND LIMITS OF THE IOWAN DRIFT.}

It seems necessary to make some statement concerning the definition of the limits of the Iowan drift. It should be understood, however, that but little work was done by the present writers on either the determination of the exact limits of this Crift sheet or on the verification or revision of the boundaries as previously mapped. The time devoted to the field work was spent, for the most part, in the study of the broader questions involved. Owing to the similarity in lithologic composition of the Iowan and the Kansan drifts, as noted above and as shown by the tabulated results of pebble counts (Tables, Appendix A) and the paucity of terminal morainal phenomena, it would probably be difficult if not impossible to determine accurately in detail the present limits of the Iowan drift. In a general way the border can probably be approximately located as at or near the places where the undissected and mantled topography of the Iowan area gives way to the dissected topography characteristic of the older drift. The drift is probably generally thin and doubtless. it has been removed by erosion from the more dissected tracts bordering the main streams. It seems to the 
writers that the line shown on the published maps is rather the inner limit of the thicker parts of the loess than the actual outer boundary of the Iowan drift, either as at present preserved or as originally deposited. While there is not a great deal of loess in the Iowan area, the Iowan drift and the loess are probably not in reality so nearly mutually exclusive. as was originally supposed. As indicated above (Chapter VII), there is in many places a certain amount of loess overlying the Iowan drift. On the other hand there are some neighboring areas showing little or no loess which the Iowan ice may not have covered.

A portion of the northeastern border of the Iowan drift is fairly well defined, and at intervals along this border there is a mild development of morainal phenomena. Five miles southwest of Ridgeway (Sumner township, Township 97 North, Range 10 . West) a tract was observed showing morainal knolls. When the tops of two of these were dug into, gravels were exposed. About a mile west of Fort Atkinson (Washington township, Township 96 North, Range 9 West, section 7) knolls of drift sprinkled with bowlders and pebbles mark the border of the Iowan. They appear to be banked at the head of a tributary of Turkey river. With these is a limestone hill forty feet high.

Three miles east of Ridgeway, on K. P. Kuntson's farm, in Winneshiek county, in section 20 of Madison township, there is a moraine, trending a little north of west. The line of hillocks rises as much as forty feet above the nearly flat, upland plain to the south. The area to the north is deeply dissected. A gravel pit fifteen feet deep in one of the hillocks shows it to be a kame. The material is rather coarse, partly water-worn gravel which ranges from sand to cobbles six to eight inches in diameter, though it averages one-half inch to one and one-half inches. It is cross-bedded, with a dip as high as 30 degrees. An estimate of the percentages of the various kinds of rock-types made by counting and sorting pebbles shows the following: 


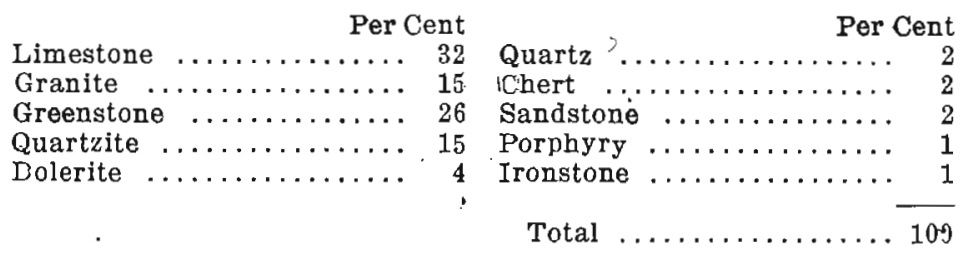

Some of the limestone pebbles, as well as some of the others, have a slight rusty and black coating. Incipient cementation is present, but so little that with the stroke of the hammer the gravel falls freely. As a result of leaching the upper five feet are barren of limestone pebbles.

Some low moraine-like knolls appear to mark the Iowan border near Conover. A cut and boring show the presence of till. The nearby kettle-like depression may really be a limestone sink and not a glacial kettle-hole.

In the northeastern part of Howard county there is a belt of swells, but so far as they were seen the knolls appeared to be of loess and not morainal. The same is true in southeastern Orleans township; Winneshiek county.

Two to three miles south of Conover, the head of a tributary of Youngs creek appears to be blocked with drift. A well here shows the presence of forty feet of drift, though drift is very thin to the eastward. It is probable that the Iowan ice extended somewhat east of this drift ridge down the broad open swales that lead to the upper terrace or second plain which is so well developed in this region. The outwash gravels extend into and through the inner gorge, which is here cut eighty feet or more below this upper terrace level.

In the northern part of Windsor township, Fayette county (Township 94 North, Range 9 West), five or six miles northwest of West Union, a moraine-like ridge lies along the border of the Iowan area as mapped. Some small sags occur with the knolls. A cut and boring in one of the swells showed seven feet of leached till over calcareous till; another cut exposed only loess.

Two to three.miles southeast of West Union (Union township, Township 94 North, Range 8 West, sections 27 and 28, and also in section 32) there are ridges and knolls at the Iowan border. 
${ }_{-\imath}$ is possible that some of these are of loess but others are certainly of drift.

Along the Iowan border between Fayette and Arlington are numerous low knolls. Some of these are of gravel, others are of loess or loess-mantled drift. It is in this belt not more than two or three miles southeast of Fayette that excavation for the railway cuts exposed the two tills with intercalated forest bed which are cited by McGee. ${ }^{62}$

The main road from Strawberry Point to Edgewood in southwest Clayton county follows a well-defined ridge which marks the border of the Iowan area. Cuts expose ten to fifteen feet of loess, but most of the bulk of the ridge is probably of till. Records of several wells show thicknesses of 100 to 200 feet of clay above the limestone.

Some knolls occur southeast of Edgewood. In section 8 Bremen township (Township 89 North, Range 3 West) a ridge of gravel knolls rises sharply in true morainal fashion thirty to forty feet above the surrounding land. The gravels are, however, oxidized brownish and considerably decomposed (about as much as the Buchanan gravel). Gravels which are exposed two to three miles farther west, in Oneida township (Township 89 North, Range 4 West, section 12, west line), are less deeply weathered.

There may be some question as to whether or not the Iowan ice really extended farther southeast and south of this point in the area east of Maquoketa river and south of the Illinois Central railroad in the southeast part of Delaware county. While the topography of the narrow upland plain between Dyersville and Farley closely resembles in part that of the typical Iowan plain, the relations of the drainage between Dyersville and Farley are somewhat anomalous, and the amount of weathering of the drift exposed and of that penetrated in several borings is greater than that commonly noted on the Iowan. The writers have therefore some doubt as to the Iowan ice having extended beyond Dyersville. East of Farley the erosion lines sharpen immediately north and south of the narrow upland strip. No calcareous material was found in the drift here

"2U. S. Geol. Survey Eleventh Ann. Rept., pt. 1, p. 487-489. 
within eight to fourteen feet of the surface. Although in numerous places, the limestone outcrops or is but thinly covered, there is some thick drift. A well on the Onstreide farm (New Wine township, Township 89 North, Range 2 West, section 35, southeast quarter), about two miles northwest of Farley, is reported to have penetrated 115 feet of drift. Apparently there is here a buried valley as the present drainage lines are cut into limestone not far away. The shifting of drainage here may account for the lack of dissection.

While the writers have not examined the area of the supposed Worthington-Barnard lobe except for parts near Worthington, it appears from study of the published description, the topographic maps, and field notes of $\mathrm{Mr}$. Leverett and Professor Chamberlin, that there is little real basis for mapping this as having been occupied by a lobe of the Iowan ice. The distribution of the bowlders and of the loess does not seem to the writers to define the limits of the Lowan, while the topographic relations render such a lobate extension inherently improbable. Doctor Calvin and some of the other observers appear to have reached the same conclusion. While there are considerable tracts of smooth, nearly flat, topography resembling the topography of the Iowan area south of the Illinois Central railway, other parts, as southeast of Delhi, are greatly dissected. Rough weathered limestone is exposed (often in projecting ledges) at numerous places and the till where seen is considerably weathered. In some places it is not, however, more weathered than the known Iowan. One hill, in this area, the sharp forty-foot ridge two miles north of Sand Spring (South Fork township, Township 87 North, Range 3 West, sections 9 and 10), is quite clearly built of Kansan drift, as the road in the crest exposes, beneath seven feet of loess, the well-marked red ferretto of the top of the Kansan till.

Two or three miles northeast of Sand Spring is a morainelike belt of hills. The gravels exposed in a pit in one of these hills (South Fork township, Township 87 North, Range 3 West, section 11, southwest quarter) are much weathered. Limestone pebbles are mostly absent from the upper part of the fifteen-foot section as they have been removed by solution ex- 
cepting some deeply etched blocks on the surface. Limestone pebbles are present lower down but some are so badly decomposed as to crumble to powder in the fingers. Granites crumble under the hammer; greenstones have rusted exteriors; clay ironstones have formed, and pebbles are much coated with iron oxide, manganese dioxide or calcium carbonate. If the Iowan ice really did extend into this area these gravels may perhaps be regarded as part of its terminal moraine. They may, however, be older.

If the Iowan ice extended onto the upland west of Cascade, it is difficult to see how it could have avoided occupying the valley of Maquoketa river, yet the constricted winding gorge below Monticello with vertical cliffs and castellated towers of limestone shows the characteristics of the Driftless Area rather than a valley so recently glaciated. It seems probable that the ice did not extend farther down than the head of this gorge near Monticello. The writers have also some doubt as to all of the gently undulating strip of country which extends from Monticello and Langworthy southeast to Onslow, having been glaciated at this time. The drift in this tract varies from one foot or less to 260 feet or more, as shown by the records of wells. ${ }^{63}$ Its undissected topography is apparently due to the results of stream shifting by the Kansan ice sheet. While the Maquoketa was forced to entrench itself in the rock but a short distance to the north, the surface configuration of this belt caused half of this area to drain in a reverse direction to the main stream at Monticello and this course has led the little brook across outcropping rock ledges. Both factors have retarded dissection; the eastern, part drains east to the main stream but this has also been retarded by cutting in limestone. The pre-Kansan or preglacial drainage was probably southward to Wapsipinicon river, but a big drift ridge now lies athwart this course. It seems to the writers probable that the margin of the Iowan ice lay across the plain somewhere east of Langworthy, but that it did not extend so far east as Onslow.

The drift ridge indicated extends northwest from. Wyoming past Amber toward Prairieburg. As shown on page 93 there Survey, Vol. XXI, pp. 528-532, 191.2. 
is good evidence that the Iowan ice overrode this ridge southeastward to a point about a mile beyond the line of the Chicago, Milwaukee \& St. Paul Railway. This is shown by the smoothedout contours of the ridge farther northwest and by the presence on top of the ridge south of Langworthy of thin Iowan drift overlying the super-Kansan soil and "gumbo." Farther southeast the ridge is much dissected, the glacial till is deeply weathered, and such traces, of the "gumbo" as have been found have no overlying later drift. It therefore seems probable that the margin of the Iowan ice lay across this ridge not far east of the line of the Chicago, Milwaukee \& St. Paul Railway. South of this it must have occupied the valley of Wapsipinicon river, though the valley slopes show little or no evidence of its presence.

From the latitude of Anamosa southward to Iowa river in Johnson county there is such an alternation of smoothly undulating plains and loess covered hilly tracts together with the dissected belts bordering the Wapsipinicon, Cedar and Iowa rivers, that there is considerable ground for difference of opinion as to just what areas were covered by the Iowan ice. It is, indeed, doubtful whether any two observers working wholly independently would reach similar conclusions. The presence of rather low, gently undulating, undissected tracts of considerable size, with here and there a big granite bowlder and even with till but moderately weathered leads, on the one hand, to the mapping of a long lobe extending fifty or sixty miles southeastward from the main Iowan area to the Mississippi near Clinton. On the other hand, the inherent improbability of the extension of a lobe of any such length and with so small a width (only eight or ten miles in southern Jones and northern Cedar counties), makes one hesitate to consent to any such mapping especially when the relative elevations of this and adjacent tracts are considered.

There is little or no evidence as to the relations of the ice front to the Wapsipinicon valley above and below Anamosa. The slopes are sharply dissected and loess-mantled. At the few places where till was seen by the writers it showed considerable evidence of weathering, such as the red ferretto zone of the Kansan. Whatever Iowan drift was deposited on these slopes 
has probably been removed by subsequent erosion or covered by the loess.

It has been supposed that the margin of the Iowan ice extended from the vicinity of Olin in southern Jones county, southeastward along the south border of the loess-mantled hills which lie south of the Wapsipinicon between Olin and Massilon. These hills appear to be of Kansan drift mantled with eight to ten feet of loess. The belt south of the Wapsipinicon between the Chicago, Milwaukee \& St. Paul and the Chicago \& North Western railway lines, has in part a gently undulating topography of the Iowan mantled type, for example north of Stanwood and Clarence. In large part, however, it is occupied by hills which, so far as is known, are principally of Kansan drift with a moderately thick coating of loess. Those with the northwest-southeast trend, the paha of McGee, are particularly notable. The writers have little data in hand showing definitely the presence of Iowan drift in this area even as far east as the Wapsipinicon valley in western Clinton county. There is even more question as to the extension of the Iowan ice farther east. The inherent improbability of the extension of such a lobe increases with the distance. This part of the Wapsipinicon valley is evidently one of the oldest valleys in eastern Iowa. It is pre-Kansan if not preglacial in origin. The relatively low elevation of the land for a distance of six to eight miles north of the stream is probably due to early denudation. Tributary valleys filled by Kansan drift have not been reëxcavated so that though there is little irregularity of the surface the thickness of the drift ranges from a foot or less, at points where the limestone is exposed, to 220 feet or more as shown by wells. Much of this area lies below the level of submergence caused by the shifting of Mississippi river through the Goose Lake channel at the time of the Illinoian ice invasion (that is, 700 to 720 feet above the sea level). From this submergence may have resulted the cleposition of much of the sand found throughout this area and as a consequence some of the smoothing of the contours. Sand deposited on the lower levels has also been blown about and has mantled some of the higher tracts. The relatively low relief, together with the relatively short time since the disappearance of the Mlinoian ice and 
the drainage of the submerged areas, has not favored subsequent dissection. These conditions may also account for the very moderate amount of modification of the till noted at several places where test borings were made in the region east of DeWitt. There is, therefore, considerable ground for question as to the Iowan ice really having invaded Clinton county to any great extent, even if it reached as far east as Wheatland. It may be possible that the Iowan ice front curved in southwestern Jones county in the region of Morley and swung southwestward to Cedar river as far west as Lisbon in southeastern Linn county, so that there may have been no Clinton lobe of the Iowan sheet. This must, however, still be regarded as an open question.

The tract west of Tipton in Cedar county which shows some Iowan characteristics is small and so isolated in the midst of a region of erosional topography that the writers are loth to think that a lobe of the Iowan ice lay over it. It differs but little from an area of little dissected Kansan upland in the southeast part of the county in the vicinity of Sunbury, yet the relations of the loess and of several paha render it like some Iowan tracts. Most of the cuts seen between Cedar Bluff and Tipton show only loess or dune sand. A cut and boring on the nearly flat upland north of Buchanan showed the presence of what appeared to be the super-Kansan "gumbo" at the top of leached and oxidized till. One boring on this upland showed calcareous till immediately below thin loess. Considering everything, and especially the erosional character of the topography surrounding this small area it seems doubtful if the Iowan ice ever occupied the tract in question.

Concerning that part of the tract north of Cedar Bluff (and the same is true of the whole belt northwest to the vicinity of Mount Vermon), Professor Norton wrote: $:^{\text {iq }}$

* * * In this limited area the aspect of the topography is abnormal in the depth of the rock-cut valleys, the width of flood plains, and the amount of dissection. The bowlders scattered over the surface and the fact that it lies in the direct and only path to the typical Iowan area west of Tipton, are, perhaps, sufficient reasons for mapping this region of western Linn township as Iowan, although the ice here passed over without

"rIowa Geol, Survey, Vol, X:I, p. 372 
altering to any marked degree the lie of the land. Here no clear marginal ridge marks the separation from the Kansan to the north and it is hard to draw the line of demarkation except by the border line of the loess and the height of adjoining Iowan areas.

It may be that the limit of the Iowan ice advance extended southwest from the region of Libson to and across the Cedar valley. The relations of the loess, the presence of paha and bowlders and a rather smooth topography led to the mapping of Iowan drift southeastward to and beyond Solon. The writers have no definite evidence of the presence of Iowan drift in this area. Kansan drift with super-Kansan "gumbo"' was observed in the dissected belt bordering Cedar river, three miles northeast of Solon as described on page 195, but with no overlying till.

If the Iowan ice really occupied the plains on both sides of the river as far southeast as Lisbon and Solon, it seems necessary to suppose that it occupied the valley as well. Subsequent erosion, mantling by the loess and the gullying of the same, have removed or obscured whatever trace of the presence of the ice was left. The same is true of the slopes bordering Iowa river southwest of Solon.

Conditions on and about North Liberty plain have been carefully studied by Mr. Leighton. ${ }^{\text {Bs }}$ Perhaps the most important evidence of the presence of the Iowan till is found in the electric railway cut north of Iowa river, described on page 117 (Plate VII and figure 10). Here there is a bed of till, presumably postKansan, overlying a crumpled bed of deeply weathered gravel. Beneath this is till regarded as Kansan. Nowhere west of Johnson county does the Iowan ice appear to have crossed or even extended to the valley of Iowa river, unless it be in the vicinity of Albion in Marshall county. The upland tract in southwestern Tama county, mapped by Professor Savage as Iowan, seems to the writers clearly Kansan.

No marginal moraine phenomena. were noted along the southern border of the Iowan area. The absence of such phenomena and the erosional character of the topography for some distance

\footnotetext{
weighton, M. M., The Pleistocene history of the Iowa River Valley, north and west of Iowa city in Johnson County, Iowa, Iowa Geological Survej. Vol. XXV, (1914), pp. 103-181, 1916 .
} 
north of Iowa river permit considerable difference of opinion as to the limits of the Iowan ice sheet.

As noted above, the writers did not make a careful and detailed study of the marginal parts of the Iowan drift such as would be necessary to determine accurately its limits in all places. However, while there is so much uncertainty about the exact limits of the Iowan drift south and west of northern Delaware county, one should not lose sight of the large amount of evidence of the presence of a post-Kansan drift in the area as a whole north and west of these uncertain limits.

\section{APPENDIX A}

\section{Tables Showing Lithologic Composition of Drift.}

In making analyses one hundred to seven hundred pebbles were collected from the drift at each of the places indicated. These were sorted and the percentages taken. These include numerous estimates made in 1907 by R. T. Chamberlin. Excepting the analyses by Mr. Chamberlin, careful determination of the different varieties of crystalline rock was not attempted, only the main groups being differentiated. The averages of the several types of crystalline rock are therefore only approximately correct. The totals of the several averages of the crystallines in each table would approximate the percentage of foreign material in the drift since no igneous crystalline rock formations occur in Iowa. Those nearest to the north are in Minnesota and Canada. The quartzites are probably principally from the Huronian quartzite areas of northwestern Iowa, eastern South Dakota, and southern Minnesota.

In collecting pebbles calcareous concretions and clay ironstones were generally avoided. These are not regarded as original constituents but as having formed in the drift since it was deposited. In making up the averages fractions have generally been discarded. 
TABLE I.

ESTIMATE OF PEBBLES FROM THE UNLEACHED WISCONSIN DRIFT.

BY R. T. CHAMBERLIN, 1907, AND W. C. ALDEN, 1914-15.

\begin{tabular}{|c|c|c|c|c|c|c|c|c|c|c|c|c|c|c|}
\hline . & 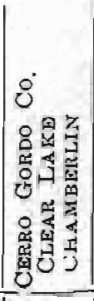 & 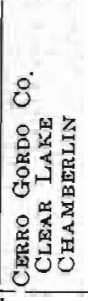 & 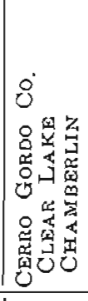 & 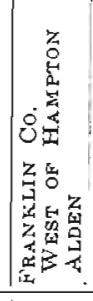 & 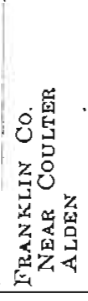 & 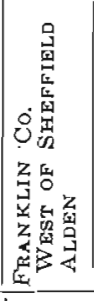 & 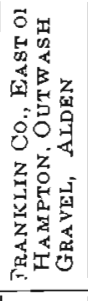 & 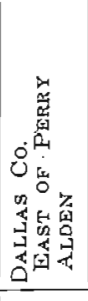 & 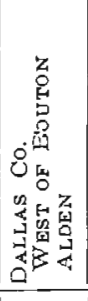 & 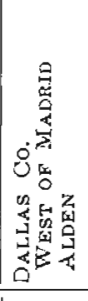 & 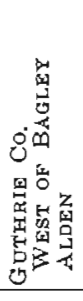 & 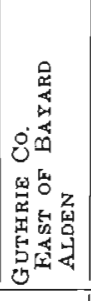 & 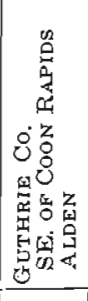 & 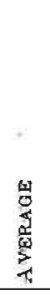 \\
\hline Grecnstone - & \multirow{7}{*}{$\begin{array}{r}19 \\
1 \\
24 \\
5 \\
1 \\
5 \\
5 \\
3\end{array}$} & \multirow{7}{*}{$\begin{array}{r}16 \\
6 \\
25 \\
3 \\
\\
2 \\
6 \\
3\end{array}$} & \multirow{7}{*}{$\begin{array}{r}14 \\
2 \\
21 \\
6 \\
2 \\
4 \\
7 \\
1\end{array}$} & 22 & \multirow[t]{2}{*}{28} & \multirow{2}{*}{12} & 11 & 23 & 21 & 26 & \multirow[t]{2}{*}{21} & \multirow{2}{*}{28} & \multirow[t]{2}{*}{20} & \multirow{2}{*}{$\begin{array}{r}19 \\
1 \\
21\end{array}$} \\
\hline $\begin{array}{l}\text { Greenstone schist } \\
\text { Granite and gneiss }\end{array}$ & & & & 21 & & & 25 & 26 & 17 & 20 & & & & \\
\hline Gabbro-diorite & & & & 21 & 10 & 12 & & & & & & & & 1 \\
\hline Syenite -- & & & & & & & & & & & & & & \\
\hline Porphyry - & & & & 3 & 4 & 6 & 10 & & & 1 & & & & 3 \\
\hline Other erystallines & & & & 1 & 22 & & & & 1 & 1 & & & & 3 \\
\hline Quartzite -... & & & & 1 & & & & & & 2 & & & 4 & 1 \\
\hline $\begin{array}{l}\text { Quartzose } \\
\text { Quartz }\end{array}$ & 1 & 2 & 3 & 2 & 2 & 2 & & & 1 & & & & & 1 \\
\hline Sandstone & 5 & 3 & 4 & & & & & & & & & & & 1 \\
\hline Dolomite and limestone & 29 & 29 & 30 & 50 & 50 & 58 & 47 & 50 & 60 & 48 & 61 & 48 & 52 & 47 \\
\hline Chert & & 1 & 2 & & & & 7 & & & 1 & & & & \\
\hline Shale _-.--1-- & & 2 & 1 & & & & & 1 & & & & & & \\
\hline $\begin{array}{l}\text { Clay ironstone } \\
\text { Hematite and jasper }\end{array}$ & 1 & 2 & 1 & & & . & & & & 1 & & & & \\
\hline Unidentified. & & & 2 & & & & & & & & & & & \\
\hline
\end{tabular}


TABLE 11 .

ESTIMATE OF PEEBLES FROM UNLEACHED PART OF UPPERMOST TILL OF IOWAN DRIFT AREA BY W. C. ALDEN AND M. M. LEIGHTON, 1914-15.

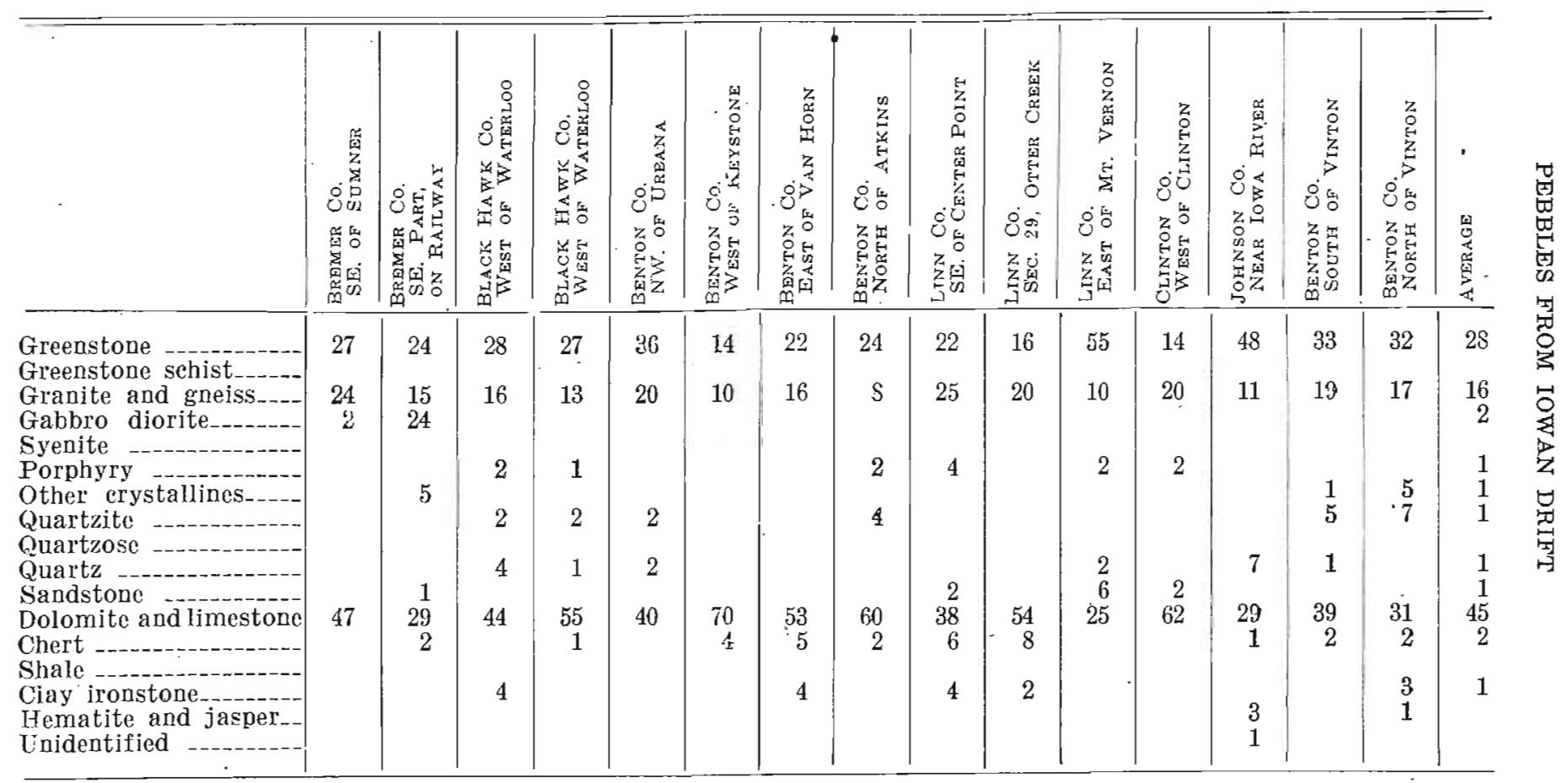


TABLE III.

ESTIMATE OF FEBBLES FROM LEACHED PART OF UPPERMOST TILL OF IOWAN DRIFT AREA.

BY R. 'T. CHAMBERLIN, 1907, AND W. C. ALDEN \&

M. M. LEIGHTON, 1914.

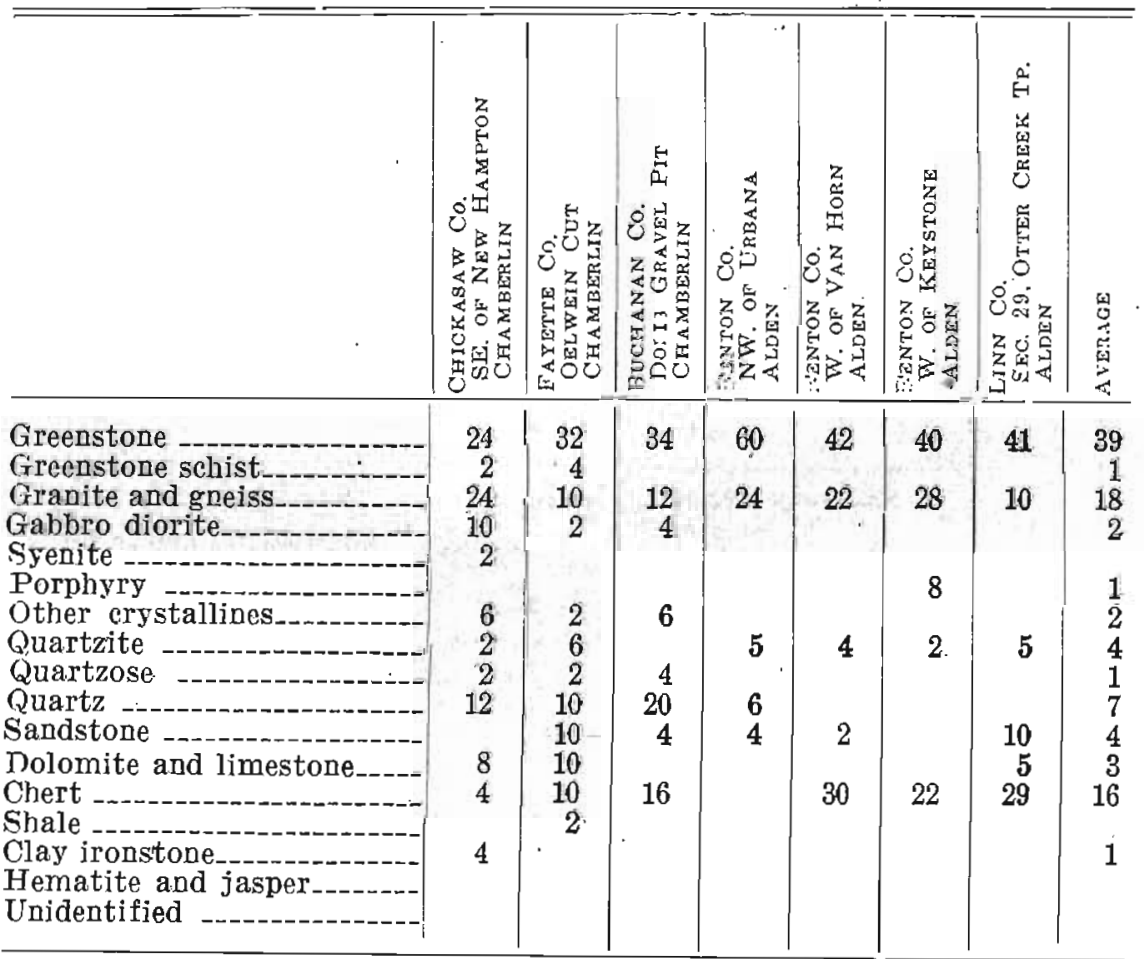


TABLE IV.

ESTIMATE OF PEBBLES FROM BUCHANAN(?) GRAVEL IN IOWAN

DRIFT AREA:

BY R. T. CHAMBERLIN, 1907, AND W. C. ALDEN \& M. M. LEIGHTON, 1914.

\begin{tabular}{|c|c|c|c|c|c|c|c|c|c|c|}
\hline & 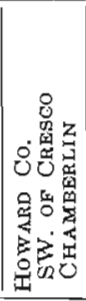 & 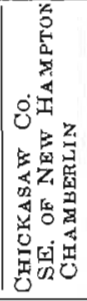 & 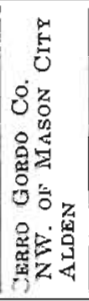 & 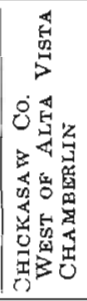 & 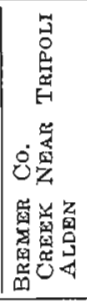 & 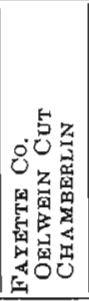 & 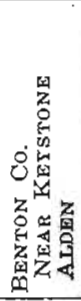 & 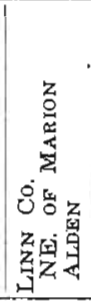 & 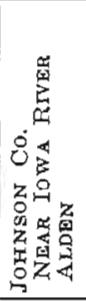 & 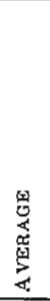 \\
\hline Greenstone --.-- & 25 & 14 & 24 & 26 & 35 & 12 & 38 & 28 & 39 & 27 \\
\hline $\begin{array}{l}\text { Greenstone } \\
\text { schist }\end{array}$ & 1 & & & & & & & & & \\
\hline $\begin{array}{l}\text { Granite and } \\
\text { gneiss }\end{array}$ & 20 & 24 & 17 & 34 & 27 & 20 & 24 & 32 & 23 & 26 \\
\hline Gabblo-diorite -- & 5 & 8 & & & 7 & 6 & & & & 3 \\
\hline $\begin{array}{l}\text { Syenite } \\
\text { Porphyry }\end{array}$ & 4 & $?$ & 1 & & & & & & & 1 \\
\hline Other & 1 & 2 & 1 & & 2 & & 2 & & & 1 \\
\hline $\begin{array}{l}\text { crystallines } \\
\text { Quartzite }\end{array}$ & $\begin{array}{l}6 \\
7\end{array}$ & 10 & $?$ & 4 & 12 & 8 & & 8 & 5 & 3 \\
\hline Ouartzose -- & & 4 & 2 & 2 & 12 & 14 & & 8 & 0 & O \\
\hline $\begin{array}{l}\text { Quartz } \\
\text { Sandstone }\end{array}$ & 6 & 18 & & 16 & 10 & 8 & & 2 & 6 & 7 \\
\hline $\begin{array}{l}\text { Sandstone } \\
\text { Dolomite and }\end{array}$ & 2 & & 1 & 4 & & 2 & & 4 & 1 & 2 \\
\hline $\begin{array}{l}\text { Dolomite and } \\
\text { limestone }\end{array}$ & 3 & 12 & 54 & & & & 14 & & 12 & \\
\hline Chert - & 8 & 2 & & 14 & 7 & 8 & 22 & 26 & $\overline{11}$ & 11 \\
\hline Shale - & & 2 & & & & 4 & & & & \\
\hline Clay ironstone & 1 & 2 & & & & 12 & & & & 2 \\
\hline $\begin{array}{l}\text { Homatite and } \\
\text { jasper }\end{array}$ & & & & & & & & & & \\
\hline Inidentified -..- & & 2 & & & & 6 & & & 3 & 1 \\
\hline
\end{tabular}


TABLE V.

ESTIMATES OF PEBBLES FROM UNLEACHED KANSAN (?) TILL OF IOWAN DRIFT AREA. BY R. T. CHAMBERLIN, 1907, AND iW. C. ALDEN \& M. M. LEIGHTON, 1914-15.

\begin{tabular}{|c|c|c|c|c|c|c|c|c|c|c|c|c|c|}
\hline . & 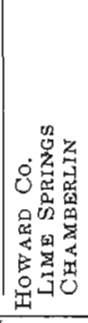 & 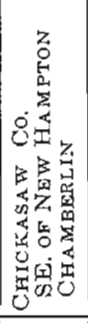 & 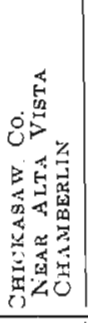 & 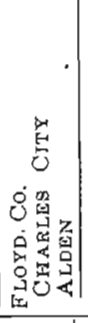 & 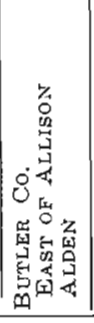 & 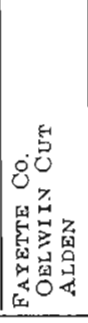 & 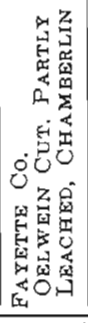 & 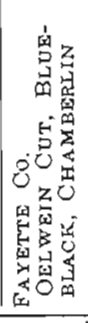 & 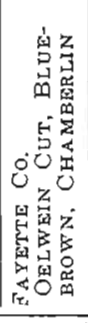 & 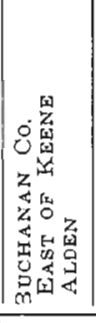 & 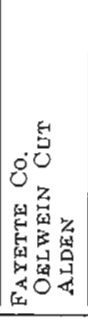 & 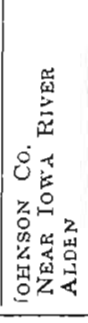 & 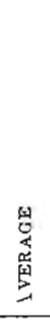 \\
\hline Greenstone - & 12 & 29 & 17 & 35 & 32 & 16 & 36 & 18 & 20 & 18 & 20 & 36 & 24 \\
\hline Granite and gneiss & $\begin{array}{r}4 \\
10\end{array}$ & $\begin{array}{r}3 \\
11\end{array}$ & $\begin{array}{r}2 \\
17\end{array}$ & 18 & 10 & 12 & 36 & 9 & $\begin{array}{r}2 \\
14\end{array}$ & 20 & 28 & $\begin{array}{l}2 \\
5\end{array}$ & 16 \\
\hline Gabbro-diorite & 4 & 4 & 8 & & & & 4 & 1 & 2 & & & & 2 \\
\hline $\begin{array}{l}\text { Syenite }-1- \\
\text { Pornhyry }\end{array}$ & & 4 & 1 & & 4 & & & & & & & & \\
\hline Other crystallines & 2 & 10 & 9 & & & & & 3 & & & & & 2 \\
\hline Quartzite & 2 & 2 & & 1 & 6 & & 2 & & & 8 & 6 & 4 & 3 \\
\hline Quartzose - - & & & & & & & & & & & & & \\
\hline Quartz & 6 & 5 & 2 & 4 & 6 & 2 & 2 & 3 & 2 & 4 & & 11 & 4 \\
\hline $\begin{array}{l}\text { Sandstone } \\
\text { Dolomite and limestone }\end{array}$ & $\begin{array}{r}2 \\
42\end{array}$ & $\begin{array}{r}2 \\
26\end{array}$ & $\begin{array}{r}6 \\
27\end{array}$ & 42 & 34 & $\begin{array}{r}2 \\
58\end{array}$ & 18 & $\begin{array}{r}5 \\
51\end{array}$ & $\begin{array}{r}4 \\
52\end{array}$ & 50 & 40 & 31 & 2 \\
\hline Chert & 4 & 1 & 2 & & 4 & 4 & & 5 & & & 4 & 8 & 3 \\
\hline Shale & 8 & & & & & & & 3 & ? & & & & 1 \\
\hline Clay ironstone & & 1 & & & & & & 2 & & & & & \\
\hline Hematite and jasper & & & & & & & & & 2 & & & & \\
\hline Unidentified & 4 & 3 & 6 & & 4 & & 2 & 1 & & & 2 & & 2 \\
\hline
\end{tabular}


TABLE VI.

ESTIMATES OF PEBBLES FROM THE LEACHED AND OXIDIZED UPPER PART OF THE KANSAN TILL OUTSIDE OF IOWAN DRIFT AREA.

BY R. T. CHAMBERLIN, 1907, AND iW. C. ALDEN \& M. M. LEIGHTON, 1914-15.

\begin{tabular}{|c|c|c|c|c|c|c|c|c|c|c|}
\hline & 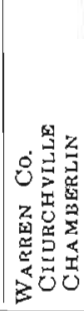 & 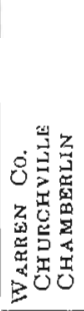 & 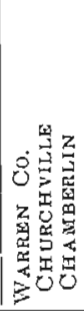 & 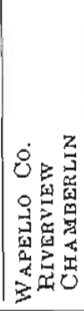 & 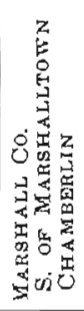 & 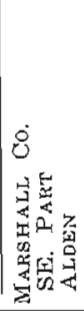 & 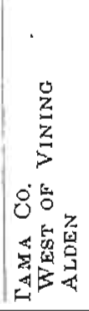 & 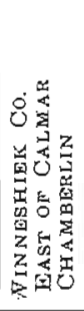 & 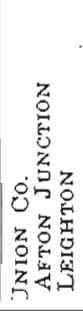 & 国 \\
\hline Greenstone - & 10 & 6 & 10 & 16 & 30 & 34 & 22 & 16 & 27 & 19 \\
\hline $\begin{array}{l}\text { Greenstone } \\
\text { schist }\end{array}$ & 2 & 2 & 2 & & 4 & & & & 2 & 1 \\
\hline Granite & $1 \overline{5}$ & 10 & 14 & 12 & 12 & 30 & 16 & 26 & 15 & 17 \\
\hline Gabbro-diorite -- & 1 & 4 & 4 & 16 & 8 & & & 14 & & 5 \\
\hline Syenite & 2 & & & 2 & 2 & & & 8 & & 2 \\
\hline Porphyry - & & & & & & & 4 & & & 1 \\
\hline $\begin{array}{l}\text { Other } \\
\text { crystallines }\end{array}$ & 9 & 6 & 2 & 2 & & & & 6 & 9 & 4 \\
\hline Quartzite & 14 & 40 & 32 & 10 & 4 & 6 & 6 & 6 & 20 & 15 \\
\hline Quartzose & 6 & 2 & 2 & 4 & 2 & & & & & 2 \\
\hline Quartz & 8 & 14 & 10 & 4 & 6 & & & 14 & 5 & 7 \\
\hline Sandstone ---- & 4 & 2 & 2 & 16 & & & & 6 & & 3 \\
\hline $\begin{array}{l}\text { Dolomite and } \\
\text { limestone }\end{array}$ & 3 & & & & 2 & 12 . & 6 & & & 3 \\
\hline Chert & 20 & 12 & 20 & 8 & 22 & 12 & 42 & & 4 & 16 \\
\hline Shale & 2 & & 2 & 2 & 4 & & 4 & & $\overline{8}$ & 2 \\
\hline Homatite and & & & & & & & & & & \\
\hline $\begin{array}{l}\text { jasper } \\
\text { radentified }\end{array}$ & & & & & & 6 & & & & 1 \\
\hline
\end{tabular}


TABLE VII.

ESTIMATES OF PEBBLES FROM THE UNLEACHED KANSAN TILL OUT SIDE OF THE IOWAN DRIFT AREA BY R. T. CHAMBERLIN, 1907, AND iW. C. ALDEN \& M. M. LEIGHTON, 1914-13.

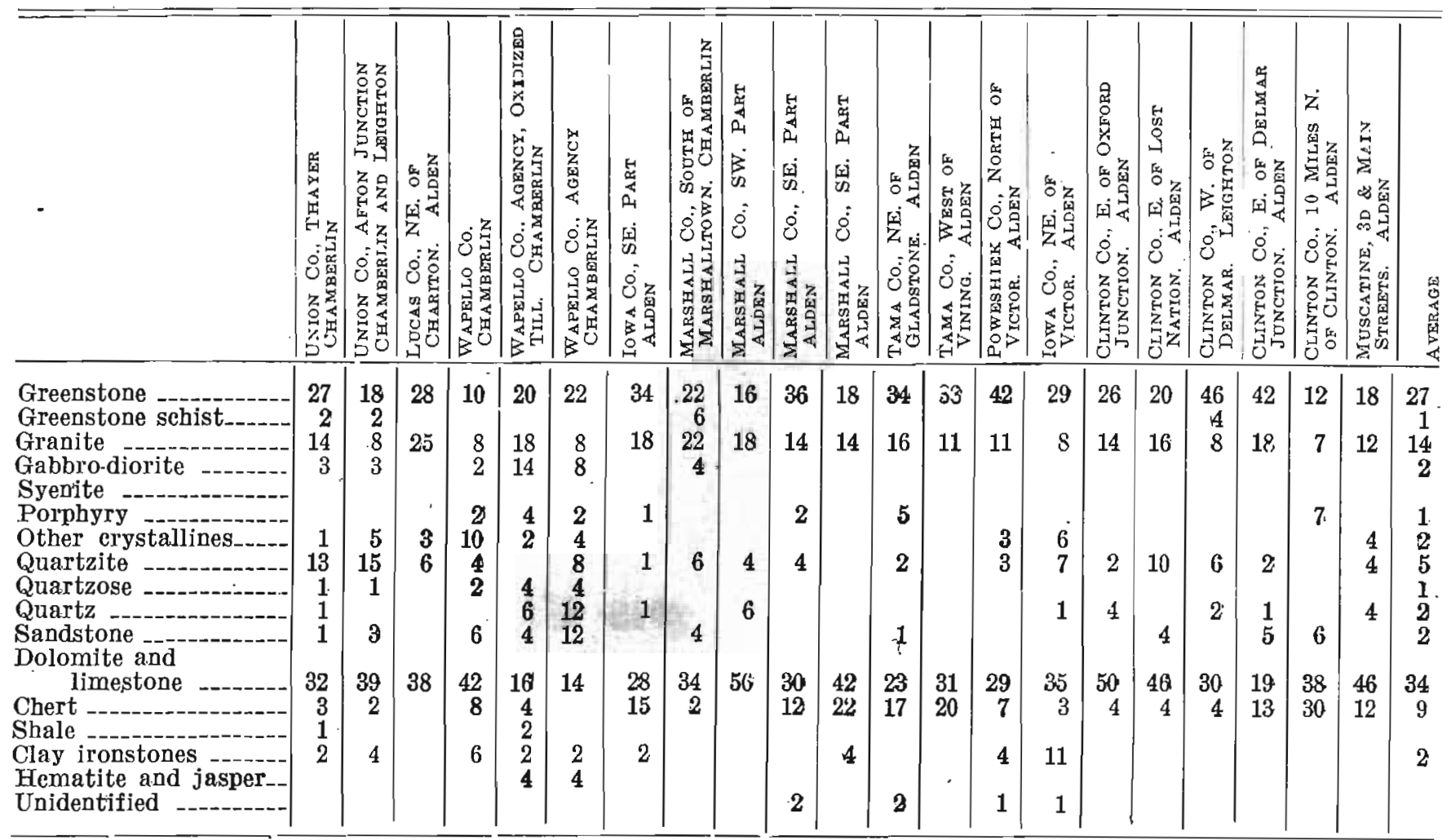


TABLE IX.

ESTIMATES OF PEBBLES FROM SUB-AFTONIAN OR NEBRASKAN TILL.

BY R. T. CHAMBERLIN, 1907, WM. C. ALDEN, 1914, AND M. M. LEIGHTON, 1915.
TABLE VIII.

ESTIMATES OF PEBBLES FROM AFTONIAN GRAVELS.

BY R. T. CHAMBERLIN, 1907, AND M. M. LEIGHTON, 1914-15.

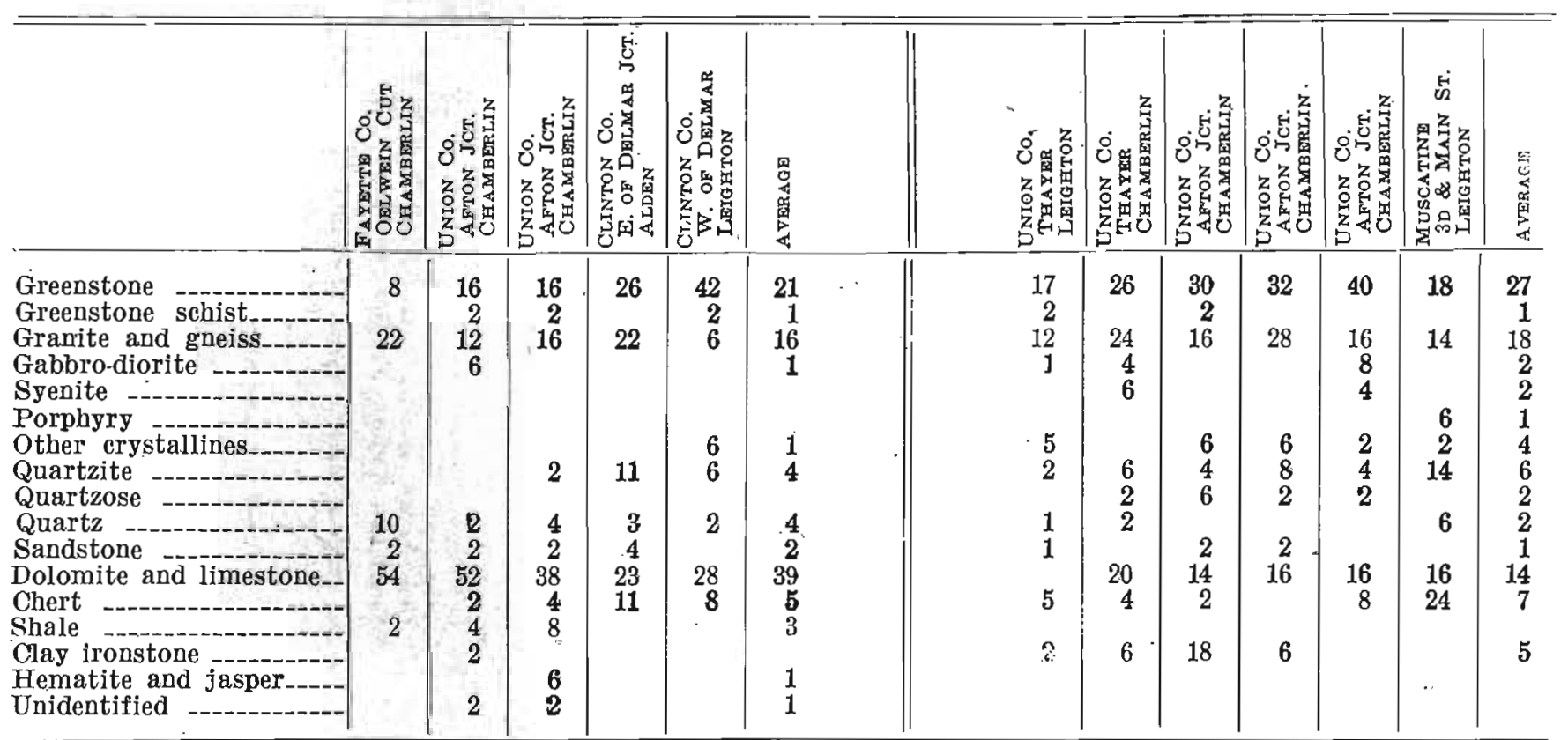




\section{APPENDIX B}

\section{Notes on Exposures of Super-Kansan "Gumbo" in the Kansan Drift Area.}

Among the most interesting exposures of what is regarded as super-Kansan "gumbo"' were those afforded by the new cuts on the Chicago, Milwaukee \& St. Paul railway in adjacent parts of Story and Marshall counties where the railroad runs eastward from the Wisconsin drift area of the Des Moines lobe into the Kansan drift area. The railway runs down a creek valley and cuts the spurs of the slopes from which in places the Wisconsin drift is absent, as it has been cut away by erosion. Going east from the first road crossing west of the Marshall-Story county line the following was noted.

\section{STORY COUNTY.}

Coldins Township, Township 82 Norte, Range 21 West, Section 13, SOUTFWEST QUARTER.

1st, $2 \mathrm{~d}$ and $3 \mathrm{~d}$ cuts east of crossing are all in Wisconsin till, calcareous nearly or quite to top.

$3 \mathrm{~d}$ cut is $30 \pm$ feet deep and the core of the spur is gray till while over that the till has grayish buff tint. This is at the block-signal.

4 th cut is for the most part all in loess. In the eastern part Wisconsin gray till is banked against and over $10+$ feet of loess.

5 th cut, gray noncalcareous "gumbo,"-face of cut sun-checked.

6th cut, gray clay, "gumbo"(?) containing lime concretions but itself noncalcareous, sun-checked, overlying buff-yellow-brown oxidized and leached Kansan till.

7 th cut for ditch on curve, yellow, oxidized Kansan till, 15 feet.

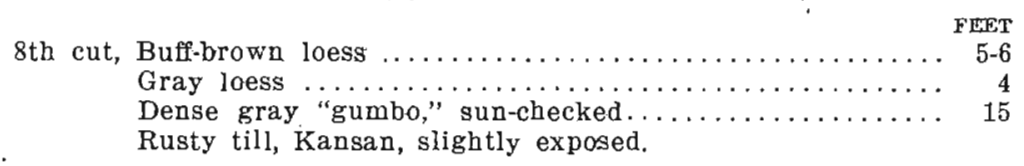

9 th cut for ditch at electric signal at county line:

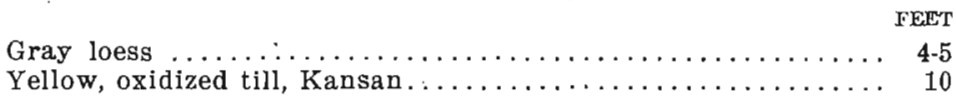

MARSHALL COUNTY.

Eden Township, Section 19 (Township 82 North, Range 20 West).

10th (bIg cut):

Buff, calcareous till, Wisconsin $\ldots \ldots \ldots \ldots \ldots \ldots \ldots \ldots \ldots \ldots$

Gray loess, contorted streaks at top, fossiliferous............

Dense, pebbleless, gray, noncalcarẹous "gumbo," sun-checked. .

Yellow, oxidized till, Kansan ....................?

Down to track and below the track in ditch as at 9 th cut.

EEET 
11 th, big cut across curve of old line, 60 feet (per barometer) deep at maximum (see Flate XIII):

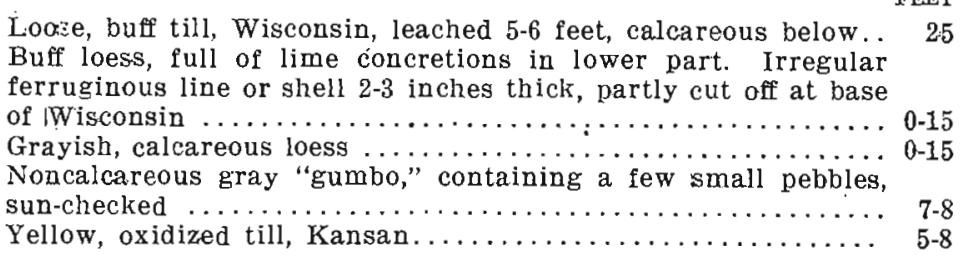

More of the Kansan till is exposed to the east as the track lowers. Where twelve feet is exposed a finely glaciated limestone bowlder three by five feet in size lies in the lower part. Farther east an equally large and finely glaciated granite bowlder lies near the top of the Kansan in the lower part or at the bottom of the gray "gumbo," which is here about ten feet thick. Near the east end of the cut is a block of gray, ripple-marked sandstone (calcareous). The loess runs down the slope to the east at least as low as the track, over the "gumbo" and Kansan till. The Wisconsin is present only at the top of the deepest part of the big cut (No. 11).

East of Rhodes, Eden township, section 10, northwest quarter, and between two and three miles east of the limit of the Wisconsin drift, the following was seen near "Station 1 mile" post (figure 14).

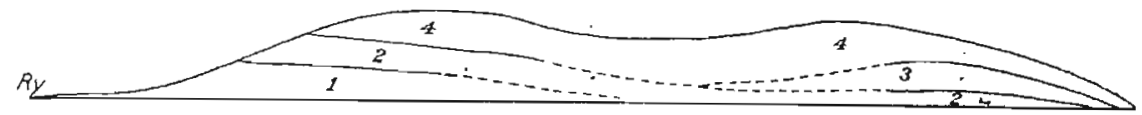

Figure 14-Diagram of drift axpreed on Chicaro. Milwaykee and St. Daul Railway cut east of Rhodes, Iowa. Aftonian (?) sand and gravel (1), Kansan till (2), super-Kansan "gumbo" (3), loess (4).

DRIT EAsT of RHoDEs, IOWA.

At west end of cut:

FEET

4. Loess, buff to grayish, leached 6-8 feet, calcareous in lower

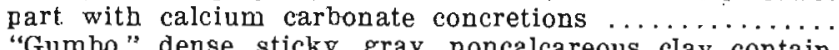

3. "Gumbo," dense, sticky, gray, noncalcareous clay containing some small pebbles (cut away to east by pre-loess

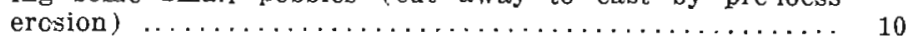

2. Till (Kansan), loose, rather sandy, rusty yellow,

Farther east in the cut and below the loess:

2. Till (Kansan), dark reddish to purplish brown at top, brown to grayish below, leached................. $6-8$

1. Sand and gravel (Aftonian?), rusty, buff to brown, loose, stratified, in places cemented by iron oxide; exposed..... 5-8 This sand and gravel extends farther east below the track level. 
A cut one-half mile east of Melbourne exposes about ten feet of noncalcareous, gray "gumbo" beneath ten feet of loess.

One mile east of Haverhill (southwest quarter of section 3 , Jefferson township, township 82 north, range 18 west) a cut on the Chicago, Milwaukee and $\mathrm{St}$. Paul railway exposes:

DRIFT EAST OF HAVERHLLI, IOWA.

FEET

4. Loess, buff, leached $\ldots \ldots \ldots \ldots \ldots \ldots \ldots \ldots \ldots \ldots \ldots \ldots$ 9.10

3. Loess, buff to gray, calcareous.................. 5

2. "Gumbo," dense gray clay, noncalcareous and containing a few small cherts $\ldots \ldots \ldots \ldots \ldots \ldots \ldots \ldots \ldots \ldots \ldots \ldots \ldots .4 .6 .4$

1. Till, Kansan, exposed at one point.

Between two and three miles south of this place (section 22, west line of northwest quarter) the "gumbo" is exposed in the road ditch below three feet of loess on the slope north of the cemetery. Here, there appears to be a gradation from the "gurnbo," which is gray and mottled rusty brown in the lower part, downward into the leached, rusty, grayish brown till below. In the gumbo are small pebbles, mostly cherts with some fragments of granite, feldspar, etc. In the gradation zone is a granite bowlder one foot by one and one-half feet in diameter which is crumbling to pieces and in which the feldspars are decomposing. The relations strongly suggest that the "gumbo" may be the product of long weathering, thorough leaching, and, finally, deoxidation of the till.

"Gumbo" was seen also in a road cut one and one-half miles north of Haverhill and in a railroad cut east of Pickering.

: POWESHIEK COUNTY.

An exposure in a road cut several miles southeast of Grinnell, Poweshiek county (Pleasant township, Township 79 North, Range 15 West, section 5, south line), showed five or six feet of dense tough "gumbo" near the top of a slope and thirty feet above the neighboring valley. The "gumbo" here is brown at the top with scattered red spots, and grayish brown below. It has a small-lump or "buckshot" texture. Similar "gumbo" was observed in a road cut at a point northeast of Grinnell (in Malcolm township, section 6 , south line of southwest quarter). The "gumbo" here outcrops in a slope about fifteen feet from the top of the hill, which is a little lower than the upland level. 
Another exposure of the "gumbo" was seen about sixteen miles farther east in a road cut on the west line of the southwest quarter of section 1, Warren township, (Township 80 North, Range 13 West) and two miles north of the railroad, near Victor. The succession in the slope just north of the southwest corner was as follows:

Drift NeAB VICTOR.

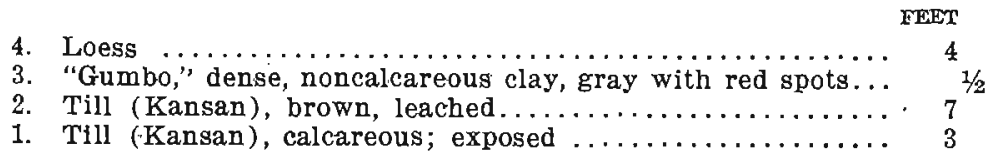

An estimate of pebbles from No. 1 is given in Table 7, Appendix A. It will be noted that it does not differ materially from the other estimates of either the Kansan or pre-Kansan drift.

IOWA COUNTY.

"Gumbo" was observed in the southeastern part of Iowa county six miles east of Parnell, near the bottom of the side slope of a small valley which cuts the north slope of the ridge between Old Man and Deer creeks (just west of the corner near the middle east line of section 3, Greene township, Township 78 North, Range 9 West). The beds exposed were as follows:

Drift East of Parnex, Iowa.

3. Loess $\ldots \ldots \ldots \ldots \ldots \ldots \ldots \ldots \ldots \ldots \ldots \ldots \ldots \ldots \ldots \ldots$
2. "Gumbo," dense, brown at top. gray below, noncalcareous,
1. Till (Kansan), reddish brown, leached.

No boring. was made to determine whether or not the gumbo extends back into the hill between the loess and the till. The "gumbo" here is sixty feet or so below the level of the highly oxidized top of the till exposed on top of the ridge one mile west, and is somewhat lower than the weathered top of the till exposed in the north-south road farther south.

Four miles south (west line northwest quarter section 27) a road cut along the side slope about twenty feet below the top of the ridge exposed: 
Drwit Southrast of Parnenx, Iowa.

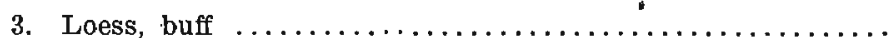

2. "Gumbo," noncalcareous clay, upper 1-11/2 feet brown with red spots, gray below........................ $5-6$

1. Till (Kansan), brownish yellow, leached.

Two miles northwest of this place (middle east line section 19) "gumbo" is exposed at about the same elevation but the cut is near the foot of the slope east of the creek and is sixty feet lower than the top of the ridge less than one-half mile north. The beds here are as follows:

Drift Sodtheast of Parnet, IOWA.

FEET

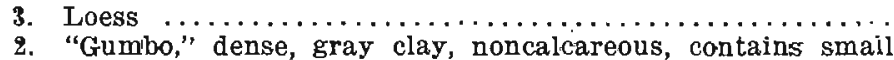
chert and quartz pebbles ..................... few feet

1. Till (Kansan), oxidized, red.

Two miles southeast of Parnell (Fillmore township, Township 78 North, Range 10 West, section 12, west line) a road cut across a spur near the upland level exposed:

DrtFt Southeast of Parinel, Iowa.

FEET

3. Loess, buff

3

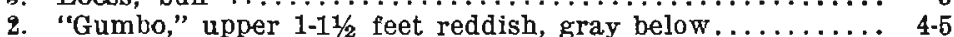

1. Till (Kansan), oxidized and leached.

It thus appears that not all the occurrences of "gumbo" are at the upland level and in places neighboring exposures at higher levels show only the red or brown oxidized till beneath the loess. Possibly some of the occurrences at relatively low levels are due to redeposition afterward from the uplands, or they may be outcrops of pre-Kansan "gumbo".

WASHINGTON COUNTY.

About eight miles west of Washington, Dutch Creek township (Township 75 North, Range 8 West, section 24, south line), gray "gumbo," sticky, gritty, and noncalcareous, was observed outcropping on a slope beneath the brown loess. This clay is pebbly a short distance below the top and contains some concretions of calcium carbonate or else it grades into till of the same color and texture. A slight exposure of the "gumbo" was seen about one mile west of Washington and another about nine miles southeast of the same place. 
JOHNSON COUNTY.

About three miles northeast of Solon (Cedar township, Township 81 North, Range 5 West, section 7, east line northeast quarter), the following was seen:

Drift NoRTHEast of SOLON.

3. Loess, buff .................................... FEET

2. "Gumbo," dense sticky, dark gray clay, noncalcareous and. containing scattered small chert and quartz pebbles...... 5

1. Till (Kansan), rusty brown, leached.

About one-fourth mile northwest, around the corner. (on the north line of the northeast quarter of section 7) the road cut exposes only loess, but a boring in the bottom, together with the cut, showed the same succession of deposits as that noted above.

A well on top of the ridge to the south was said by the owner to penetrate 228 feet of drift, mostly clay with sand at the bottom. Some wood was encountered about 200 feet from the surface, or about 150 feet lower than the "gumbo." W. Verba's well in section 6 is reported ${ }^{68}$ as being drilled through the fol. lowing deposits :

LOG OF W. VERBA'S WELL.

TEET

4. Reddish clay (loess or Kansan?) ................ 20

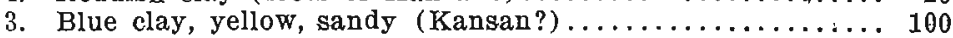

2. Black soil (Aftonian?) ..................... 2

1. Brownish clay and yellow clay (pre-Kansan) above rock. 10

CEDAR COUNTY.

About six miles west of Tipton (Cedar county, Cass township, Township 81 North, Range 3 West, section 31, south line of southwest quarter) a shallow road cut on the nearly flat upland exposes rusty, ashen-gray, pebbly clay with the texture and appearance of "gumbo." In a boring here the auger penetrater the following:

\section{DEIFT WEST OF TIPTON, Iowa.}

Brownish gray pebbly clay, "gumbo"? ............ FETT

Till (Kansan?), brown, leached.................... 3

Till (Kansan?), brown, calcareous.

It is suggested that this gently undulating plain, some fifteen square miles in extent, which has been mapped as Iowan, may be a remnant of the Kansan upland whose dissection has been retarded by the gorge cutting of Cedar river between Cedar Bluff 
and Rochester and by the tributary streams having to work so much in limestone. Most of the surrounding area and especially that to the south, is much dissected, with 50 to 150 feet of relief.

About four miles southwest of Lowden (Springfield township, Township 81 North, Range 1 West, section 16 near center) a road cut on the lower part of a small spur showed, below three and one-half feet of loess, two and one-half feet of "gumbo," reddish brown, noncalcareous, with "buckshot" texture and containing sand grains and a few small pebbles.

A small exposure of "gumbo"-like clay was seen on the west side of Cedar river, two miles west of Moscow (Muscatine county, Moscow township, Township 77 North, Range 2 West, section 8; southwest quarter). At this place, below five to fifteen feet of leached buff loess is dense, gray, noncalcareous "gumbo-" like clay two to two and one-half feet thick, which carries as many pebbles as the till below. There is a dark, carbonaceous band at the top which seems to be due to vegetal growth in an old soil. The pebbly "gumbo" grades below into brown stony till. This exposure is but twenty to forty feet above the bottom land (at 660 to 680 feet above sea level) so it probably does not correspond to the super-Kansan upland "gumbo."

\section{CLINTON COUNTY.}

Going northeast across the gently undulating plain of the socalled Clinton lobe one reaches the higher hills of the loess-Kansan tract on the north. Here is a greatly dissected area with 100 to 150 feet of relief and with steep slopes sharply cut by frequent $V$-shaped ravines. At many of the places where the till is exposed beneath the loess its upper part is oxidized to a deep red ferretto. In a few cuts there was seen, in place of this, a well-marked bed of "gumbo". About eight miles northeast of DeWitt (Washington township, Township 82 North, Range 4 East, section 22 , east line of the southeast quarter, at $760^{ \pm}$ feet above sea level) a cut in the slope fifty to sixty feet below the upland level exposed the following: 
Drift Northeast of DeWitt, Iowa.

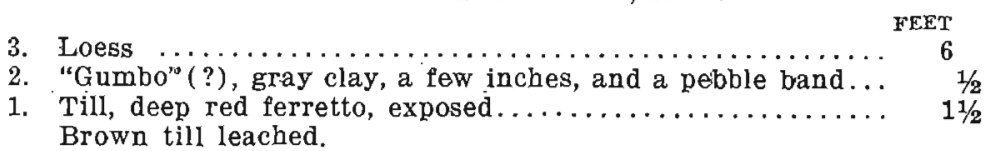

Three miles to the southeast (Center township, Township 82 North, Range 5 East, section 30, east line of the northeast quarter, at $770 \pm$ feet above sea level) the "gumbo" is five feet thick. It is dense, noncalcareous, gray, and blackened at the top by carbonaceous matter which resembles an old soil. This contains plentiful small pebbles, most of which are chert and 'quartz although some are crystallines. Beneath lies the till. Near the middle of the south half of the same section, one-half mile distant, what appears to be the same bed of "gumbo" is slightly exposed below a grassed bank ten feet high which is probably of loess. The exposures are twenty to thirty feet below the top of the loess-mantled ridge.

In the much dissected elevated tract in the northwest part of Clinton county, at one point (Sharon township, Township 83 North, Range 1 East, section 9, middle of the south line) there was noted beneath the loess on the slope, three feet of dense, brown to gray clay containing small chert and quartz pebbles and much like the "gumbo" in texture. This grades downward into stony till. This exposure is in a cut on the steep slope, about sixty feet below the top of the ridge. Other cuts, some nearer the upland level, show only the deep red ferretto at the top of the till and beneath the loess.

\section{JONES COUNTY.}

Several miles farther west another deposit which suggested the super-Kansan "gumbo" was seen at a point two to three miles north of Oxford Junction (Oxford township, Township 83 North, Range 1 West, section 10, north line of the northeast quarter). The exposure is on the slope of a lobe of the ridge, about thirty feet below the top. Beneath three feet of brown loess is a much decayed brown gravelly drift. The granite and greenstone pebbles are so decomposed as to be readily cut through. Near the top of the drift are streaks and patches of gritty gray clay which suggests "gumbo". This clay increases 
in amount in the lower part of the exposure as though it were due to more thorough decomposition below the gravelly top. In the lower part of the seven foot bed it becomes a mixture of light gray and dark, rusty, brown clay full of arkosic material. This appears not to be a deposit distinct from the underlying till but is in reality the much-weathered, upper part of the till so far decomposed and with so much of the soluble material removed that it approaches in character the super-Kansan "gumbo", seen elsewhere.

Northwest of this point along the high-ridged and much dissected belt of thick drift, numerous cuts expose the deeply oxidized upper part of the till beneath the loess mantle, but no other remnant of the "gumbo" is known east of the Monticello-Anamosa road and here the "gumbo"' is overlain by Iowan till.

\section{SCOTT COUNTY.}

Between four and five miles west of LeClaire, Scott county (LeClaire township, near middle of the east half of section 36 , Township 79 North, Range 4 Eist), an interesting exposure was observed in September, 1915, as follows:

DRIFT NORTHEAST OF DAYENPORT, IOWA.

FEET

4. Loess, buff $\ldots \ldots \ldots \ldots \ldots \ldots \ldots \ldots \ldots \ldots \ldots \ldots \ldots \ldots . \ldots \ldots$. $10-12$

2. "Gumbo" (super-Kansan), dense, gray, noncalcareous clay, showing a fine network of rusty seams and containing a few small polished quartz pebbles and chert fragments.... 4-5

1. Till (Kansan?), rusty brown, with disintegrating crystalline pebbles up to 1 foot in diameter. Low'er down the color becomes lighter brownish yellow, and the till is calcareous with, in one place, a thin crust of calcium carbonate several feet long.

The gray "gumbo" (No. 2) is different in texture from the gray loess above, being more dense and sticky and containing. pebbles. It resembles the super-Kansan "gumbo" farther west. The till resembles the Kansan, and the Illinoian till is apparently absent at this point.

\section{ROCK ISLAND COUNTY, ILLINOIS.}

The upland south of Mississippi river in Rock Island county, Illinois, is considerably dissected by erosion and much of the Illinoian till may have been removed before the loess, which is 
one to fifteen feet in thickness, was deposited. It appears to be absent at the following places. About three miles southeast of Illinois City in Buffalo township (Township 16 North, Range 4 West), just east of the middle of the west line of section 20, the following was observed in a road cut, in September, 1915:

DRINT IN ROCK IISLAND COUNTy, ILLINOIS.

3. Loess, brown

2. "Gumbo," dense, gray, noncalcareous, containing small cherts and some small crystalline pebbles........... $3 \pm$

1. Till, brown, leached.

About one and one-half miles farther south just south of the middle of section 29 , the following was seen:

DRIFT IN ROCE IISLAND COUNTY, ILLINOIS.

3. Clay ("gumbo"?), rusty gray ......................

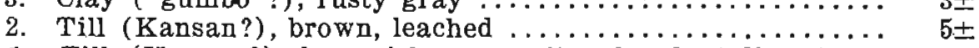

1. Till (Kansan?), brownish gray with abundant limestone pebbles.

GUMBO BENEATH ILLINIOIAN TILL, LOUISA COUNTY, IOWA.

In this connection it may be noted that the Kansan drift and super-Kansan "gumbo" have been observed beneath the Illinian drift in both southeastern Iowa and western Illinois.

Certain exposures examined on the upland south and west of Wapello showed:

DRTF IN SOUTHWESTERN LOUTSA COUNTY, IOWA.

5. Loess, brown ......................... FEET

4. Till (Illinoian), brown and leached but containing lime-

stone fragments ......................... 5-10

3. Clay (silt or "gumbo," super-Kansan), gray, with some small pebbles .......................... 2-3土

2. Till (Kansan), brown, leached, rusty red on joint faces... 6-7

1. Till (Kansan), brown, calcareous................. $5 \pm$ Limestone.

HENRY COUNTY, ILLINOIS.

A "gumbo" which was seen at one exposure in Henry county, Mlinois, is quite certainly super-Kansan, as it is overlain by Mlinoian till. The exposure is on a spur crossed by the road and east of the creek and is about seven miles south and three miles west of Cambridge, in Clover township (Township 14, Range 2 East, section 14, south line of the southwest quarter). It shows the following: 
4. Clay, brown, loesslike in upper part but with small pebbles lower down. These increase in size and number downward into (3) ........................... few feet

3. Till (Illinoian), brown, leached in upper part, calcareous below, with calcium carbonate concretions .......... 10

2. Clay (super-Kansan "gumbo"), gray, noncalcareous, sticky, containing small cherts and some lumps of rusty, fer-

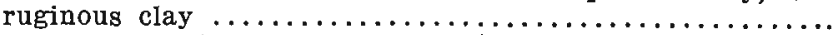

1. Till (Kansan), gray, calcareous, containing rusty iron oxide masses and becoming more uniformly brownish lower down.

This occurrence taken with those cited above indicates quite surely that there is a super-Kansan "gumbo" bed underlying. the Illinoian till. This is clearly distinct from any superIllinoian "gumbo".

\section{APPENDIX C.}

\section{Occurrences of Drift, Possibly Iowan.}

WIINNESHIEK COUNTY.

In a boring at a point three miles southwest of Ridgeway (in Lincoln township, Township 89 North, Range 10 West, section 28 , middle of west line), the following beds were penetrated:

DRLT SOUTHWEST OF RIDGEWAY, IOWA.

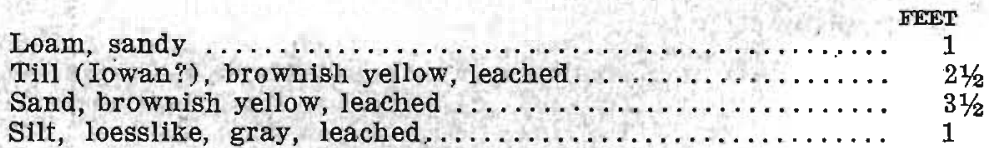

CERRO GORDO COUNTY.

The only exposure seen outside the Wisconsin area in Cerro Gordo county which suggested the presence of post-Kansan till was in Portland, township, section 17, southeast quarter. A road cut in the abrupt thirty-five foot slope east of Lime creek showed the following:

DrjFt Between Mason CrTy and Portuand, Iowa.

4. Clay, dense, gray, pebbly, lying unevenly on No. $3 \ldots \ldots \ldots, 0-4$

3. Sand, in irregular streaks .................... few inches

2. Clay, dense, purplish, leached, "gumbo"-like, uneven as though disturbed $\ldots \ldots \ldots \ldots \ldots \ldots \ldots \ldots \ldots \ldots \ldots \ldots, 0.1$

1. Till, highly oxidized, reddish, gritty, leached, pebbly. No limestone pebbles seen, granites' disintegrating.......... $5-8$ 
Number 1 looks like the Kansan ferretto of southern Iowa. Numbers 2 and 3 were present only in the north side of the cut. The upper pebbly clay, Nos. 4 and 5, might represent a distinct till sheet later than No. 1, though this clay could not with certainty be said to be till.

\section{FLOYD COUNTY.}

The writers, in company with Prof. A. O. Thomas, examined the following section exposed at an old quarry in the southern part of Charles City:

Drift at KuhNle's Quarry, Charles City, Iowa.

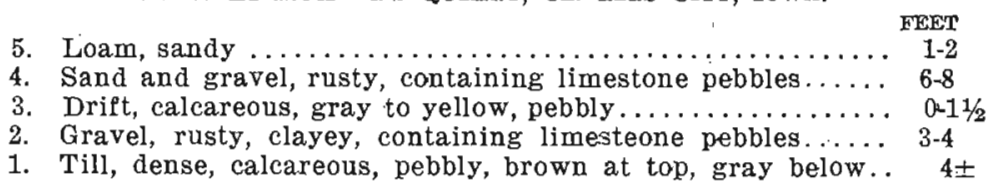

Limestone surfaces show striæ bearing south-southeast. According to Professor Thomas, Professor Calvin, who examined this exposure with him, regarded No. 1 as Kansan till, No. 2 as Buchanan gravel, and No. 3 as Iowan drift. To the present writers it seemed very uncertain that No. 3 was a distinct deposit of glacial till.

\section{CHICKASAW COUNTY.}

A road-cut three miles south of Lawler (Stapleton township, Township 95 North, Range 11 West, section 3, west line of the southwest quarter) exposed rusty brown to yellow sand and gravel, poorly assorted, leached throughout, cemented in places at the bottom by iron oxide. At one end buff leached till, which ranges from nothing to six feet in thickness, overlies the rusty gravel and includes a bowlder of the cemented gravel conglomerate besides granite bowlders up to four feet in diameter. The relations are not very clear and the till is not certainly an entirely distinct deposit.

\section{BREMER COUNTY.}

No exposures were seen showing a recognizably distinct, later till overlying an earlier till. The phenomena are as portrayed in the general description. In boring on a hill in Warren township (Township 92 North, Range 13 West, section 34, south 
line of the southwest quarter), the following deposits were penetrated:

DrIFT Five Mnes East of WaVerLy, IOWA.

5 Dark pebbly soil and yellow pebbly clay till leached

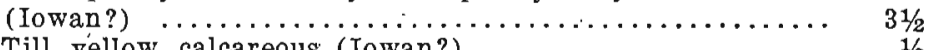

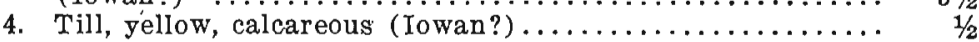

3. Ashen-gray, pebbly clay till, calcareous $\}$ (Kansan?) .... 1

1. Yellow', clayey till, calcareous $\ldots \ldots \ldots \ldots \ldots \ldots \ldots \ldots \ldots \ldots$ Boring stopped by bowIder or bedrock.

There is here a suggestion of a thin later till overlying the bleached, but not leached, upper part of a thin lower till. The basis for separation is, however, very slight and uncertain.

\section{FAYETTE COUNTY.}

So important has a certain section near Oelwein been regarded that it may be well to present here some of the data concerning it. The cut is on the Chicago Great Western railway, southeast of Oelwein (in Jefferson township, Township 91 North, Range 9 West, sections 27 and 28). When the cut was seen by the writers in 1914 the sides were badly obscured by slumping and vegetation excepting in the upper part. By digging at a point about 200 yards east of the north-south viaduct, the following section was made out:

Dritt Near Oelwetiv, Iowa.

10. Black soil and brown loam with occasional pebbles......

FEET

9. A line and a lenticular accumulation of pebbles and cobbles up to 5 inches in diameter (lens 10 inches deep

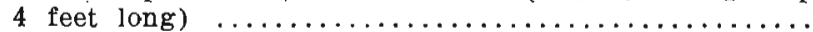

8. Till, yellowish brown, leached $3 \frac{1}{2}$ to 4 feet, calcareous, buff in upper $11 / 2$ feet with mottlings of brown, then changes to gray with less brown mottling for $1 \frac{1 / 2}{2}$ feet, then in lower 6-10 inches it becomes gray-blue with streaks and mottlings of brown, total till............

7. Humus clay, chocolate brown, rusty brown streak separating from till above, leached, rests in basin-like depression, almost 2 feet thick at sides and 3 feet in middle...

- Dense clay, difficult to dig, no pebbles seen larger than buckshot, most of them mere quartz grains but even these rare; clay mainly blue, but blue-black just below

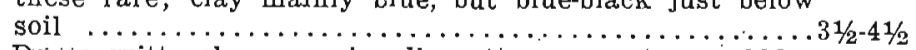

5. Dense gritty clay, occasionally rotten greenstone pebbles $1 / 4$ inch in diameter, dark green in color; leached......

4. Sandy clay, pale green, occasionally a greenstone and quartz pebble $1 / 4$ inch in diameter; leached...........

3. Brown sandy clay, pebbles up to 2 inches in diameter, 


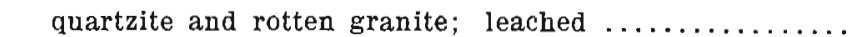

2. Blue clay with same kind of pebbles as above..........

1. Sand and gravel, leached, light brown, loose, rotten granite pebibles found in it, just exposed at bottom for....

Number 10 does not seem to be till but an accumulation perhaps of wind-blown dust, humus, fine material brought up by burrowing animals and only an occasional pebble such as would be expected to be brought up by them or washed in. Number 8 is not separable into two tills. It is probably all Kansan. It is true that the upper six inches to one foot is more sandy than the lower part and is slightly darker brown but not more than would be expected from the material that was last deposited by the ice and subjected to wash from its waters, to later weathering and to frost action. In places there is a, slight. color and textural distinction between the leached portion and the underlying calcareous part, but no sharp line can be drawn. This distinction probably is the result of leaching, leaving the leached portion slightly more sandy. Number 7 is clearly a soil zone (Aftonian). Below this the dense clays appear to be silts, the result of pond deposition and similar processes. Numbers 2 and 3 may be till but this is by no means clear.

The only indication seen by the writers that the uppermost oxidized till might be distinct was the presence at two places of three to three and one-half feet of brown or yellow sand below it. This was traceable but a short distance laterally and in itself constitutes only a very slight basis (if any) for the separation of a post-Kansan till sheet.

In July, 1907, R. T. Chamberlin examined the exposure. The following is from his notes concerning this cut:

There has been so much slumping here that much digging is necessary before the section can be made out. According to an intelligent railway foreman who was present when the cut was made (9 to 10 years ago) and who had much to do with the making of the cut, the cut was originally left as a very steep bank (vertical steam shovel bank) and the present slope is entirely due to slumping and wash. The section when fresh must have been a good one, but at the present time it can only be pieced together with much digging. A section made at a point 100 feet north of the milepost was as follows: 
1. Kansan drift. Upper 8 feet yellow brown, somewhat speckled with light grayish blue mottlings. Not a very hard clay here. The upper portion has been cut off by the Iowan ice and some of that drift has mixed in. It has been leached down 5 feet. Then come 4 feet of dark bluish hard, chunky clay with the upper portion of it grading rapidly into the brownish drift above. Total thickness............

2. Aftonian.

(a) Red brown sand $2-4$ in., a highly oxidized interglacial sand.

(b) Layer of solid humus 1 in.

(c) Clay containing much vegetable humus. Color in upper portion dark reddish brown with a lavender cast; in lower portion ordinary rusty reddish brown. Vegetable matter chiefly in upper part. Total thickness..

EET IN. Glsewhere nearby there is some variation in the thickness of this colored clay, especially in its downward gradation.

3. Sub-Aftonian. Light grayish blue, hard clay, becoming darker below. Contains very few pebbles. Only the upper foot or two could be seen even with considerable digging on account of the great amount of wash material. Height of top of this drift above

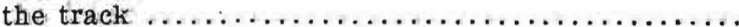

J. Mullin, the foreman who saw the cut dug and who has since dug six feet below the level of the track to put in tiling, says that this clay becomes darker blue and much harder below, and that it extends as one uniform formation to at least six feet below. the present level of the tracks.

Apparently the portion of the sub-Aftonian seen was only the top of the unoxidized material where, like the Kansan, it has become lighter in color but not yet oxidized to brown. The clayey layer above (2c) represents the weathered portion which in the upper part has been modified by vegetable matter. Above this is the solid humus layer representing the surface upon which the interglacial gravels were laid. Upon the gravels rests the blue-black Kansan till without a soil line.

Mr. Mullin brought me a slab of peaty material one and onehalf feet in diameter and about one inch thick, which came from the one inch humus layer when the cut was first dug and which (together with much more of the stuff) has lain on the old dump pile ever since. This breaks off in layers and resembles "old leather" somewhat. He has also found fragments of wood at this level.

[See Appendix A, table No. 5, for estimate of pebbles from the Kansan drift.] 
One hundred feet to the south (at the 1 milepost) the reddish brown Aftonian is found in a small gully. Below this is the blue black till which may be sub-Aftonian though there is a possibility that it is Kansan, the Aftonian having been incorporated in the Kansan ice. In some respects this looks like a lens of Aftonian but there is so little of it exposed and so much slope wash about that it is uncertain.

It may be called sub-Aftonian doubtful and classified as such. There were more pebbles in this than in the topmost part of the sub-Aftonian in the last section.

[See Appendix A, table No. 9 for estimate of pebbles from the sub-Aftonian.]

Section at milepost [correction for upper part of section described above]. The upper five feet of this section are grassed and the Iowan was missed, but can be found thirty feet to the northwest. At this point are four feet of yellow brown, noncalcareous Iowan drift which does not break in chunks like the Kansan and is also fresher in appearance. Below it are two inches of yellowish sand. Then comes calcareous, yellow-brown Kansan, as described above. Hence Kansan is only seven feet thick here, though elsewhere in the cut it is usually more than this.

This cut is through a ridge of highland and hence (the topography being chiefly pre-Iowan) was likely to be subject to erosion by the Iowan ice. This is probably the reason why Kansan is found to be calcareous up to its top. The leached zone has been eroded away.

[See Appendix A, table No. 5 for estimate of pebbles from the Kansan.]

The first cut two-thirds mile from the station shows the Iowan drift to better advantage than the deeper cut farther on, for the steam shovel has been in here recently. The section is:

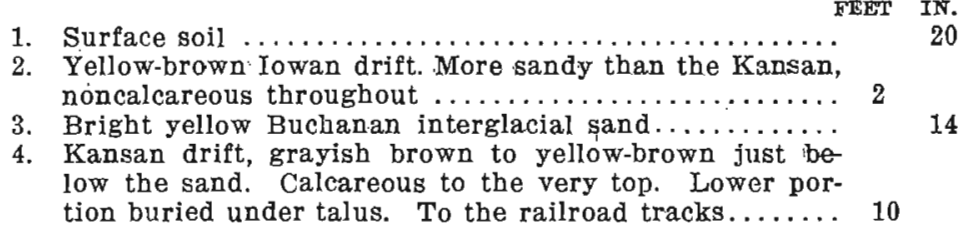

The Kansan is streaky in color and breaks off in chunks; the Iowan is uniform in color and though hard does not break into chunks.

[See Appendix A, table No. 3 for estimate of pebbles from the Iowan.] 
One hundred yards farther on the Iowan becomes more varied in color, being yellow, brown, and gray in patches. It is very hard, especially when dry, but does not break in chunks like the Kansan. It is noncalcareous.

The Buchanan interglacial sand here becomes quite gravelly. The section is :

1. Hard, tenaceous, yellowish brown, or grayish brown Џowan drift. Thickness including surface soil ............. 6

2. Buchanan sands and gravels ......................

3. Brownish Kansan drift to tracks................. 7

[See Appendix A, table No. 4 for estimate of pebbles from the Buchanan gravel.]

The following is a description by Prof. S. W. Beyer ${ }^{08 a}$ from an examination of the cut soon after the excavation was made.

Oelwein Section.-The cut on the Chicago Great Western Railway, east of the town of Oelwein, in southern Fayette county, exhibits the following series of glacial deposits:

5. Bowlder clay, rather dull-yellow in color; the upper portion is modified into a thin soil layer. Large bowlders, mainly of the granitic type, are present, often resting on or partially imbedded in the deposits lower in the series. (Iowan)........... 0-10

4. Sand and gravel-not a continuous deposit; often shows water action expressed in parallel stratification lines and false bedding. The gravels are usually highly oxidized and fine textured. (Buchanan) ... 0- 2

3. Till, usually bright-yellow above, graduating into a gray-blue when dry or a dull-blue when wet, below. This deposit is massive and exhibits a tendency to joint when exposed. Decayed granitic bowlders are common. (Kansan) ...................... 3-20

2. (a) Sand, fine-white, well water-worn; often with a slight admixture of silt and clay (Aftonian) ........ (b) Vegetal layer and soil, from two to four inches of almost pure carbonaceous matter, with one to three feet highly charged with humus. The peaty layer often affords specimens of moss (Hypnum) perfectly preserved. (Aftonian)............ 0-4

1. Till, greenish-blue when wet or gray-blue with a greenish cast when dry. Greenstones and vein guartz pebbles predominate. (Sub-Aftonian or Albertan.) Exposed

Beyer, S. W., Evidence of a sub-Aftonian till sheet in northeastern Iowa; Proc. Iowa Acad. Science, Vol. IV, p. 59. 


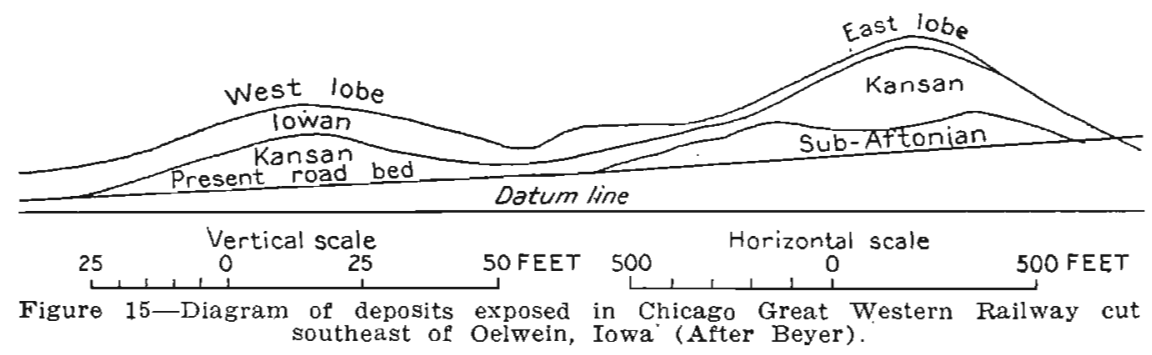

Professor Beyer gives the above sketch of the cut (figure 15). Following the section quoted, Professor Beyer, in his paper which deals particularly with the sub-Aftonian till, makes the following statements concerning the Iowan:

The Oelwein hill trends northwest and southeast and is bilobed. The divisions will be referred to in the present paper as east and west lobes.

The Iowan reaches its maximum development near the summit of the west lobe, where it attains a thickness of some ten feet. The deposit thins eastward. At the crest of the east lobe little more than a foot of Iowan till is present, while at the extreme eastern limit of the cut Iowan bowlders are partially imbedded in the Kansan. The till varies from a pale yellow to a moderately bright yellow color, and is not thoroughly leached nor oxidized. The Iowan shows a tendency to crumble on exposure, which is in striking contrast to the older drift sheets.

The line of separation between the Iowan and Kansan is not as well marked, in all cases, as could be desired, but in most instances can be traced with some degree of confidence. In the west lobe a layer of sand sharply divides the two sheets for a distance of 100 feet, but when followed in either direction becomes much disarranged by the latter and in some places entirely loses its identity.

The Kansan is the predominant sheet in the cut and the topographic features of the region are faithfully depicted by the stiff bowlder clay of this deposit. Its maximum exposure is in the east lobe, where it exhibits a thickness of twenty feet. The upper portion is oxidized to a bright yellow, sometimes brownish-yellow; often closely resembling the Iowan in color. The most distinctive feature in its separation from the latter is the character of the included bowlders and the greater tenacity of the Kansan till. The Iowan pebbles and bowlders are prevailingly of the granite type and well preserved, while in the Kansan, greenstones are common and many of the granites are 
in an advanced state of decay. A granitic bowlder more than a foot in diameter was noted which had been cleaved by the steam shovel without being loosened from its matrix. Sand bowlders, lenses and wedges anomalously distributed through the oxidized portion and often extending into the upper portion of the blue till are common features. The wedges usually maintain a more or less vertical position with their apices pointing downward. The filling material in all cases closely resembles the sand layers between the Iowan and Kansan. Oftentimes the position of the various sand forms is such as to suggest their common origin with the Buchanan. In many instances stratification lines are common. In the trough of the hill, the lower portion of the Kansan contains lime concretions similar to the loesskindchen and puppchen in great numbers. The lower three or lour feet of the blue till contains wood fragments in considerable abundance in a state of almost perfect preservation. The physical properties of this portion of the Kansan are very similar to the sub-Aftonian.

[?'he estimates of lithologic character of the pebbles made by Mr. Chamberlin from the Iowan and Kansan and by Alden and Leighton from the Kansan do not indicate any marked lichologic difference between the Iowan and Kansan in this cut. See Appendix A, tables 3 and 5.]

DELAWARE COUNTY.

Doctor Calvin ${ }^{\text {e7 }}$ reported Iowan drift as overlying Buchanan gravel at scores of points within the county. W $J \mathrm{McGec}^{\mathrm{us}} \mathrm{re}$ ported the discovery of buried soil and wood in wells in Greeley and southeast of Masonville in Prairie township, (Township 88 North, Range 6 West, section 35, southwest quarter of the northwest quarter), but Professor Calvin regarded these as belonging to the Aftonian horizon. ${ }^{69}$

\section{BUCHANAN COUNTY.}

In discussing the Buchanan gravel Doctor Calvin ${ }^{70}$ refers to the county gravel pit near the Illinois Central railway, two miles west of Winthrop (Liberty township, Township 88 North, Range 8 West, section 4, northwest quarter), and writes:

\footnotetext{
TIowa Geological Survey, Vol. VIII, p. 170.

BIT. S. Geol. Survey Eleventh Ann. Rept., p. 520.

${ }^{60} \mathrm{Op}$. cit., pp. 164-5.

${ }^{70}$ Iowa Geological Survey, Vol. VIII, p. 242, 1897.
} 
* * The line of division between the gravel and the overlying Iowan drift is also well shown, and at the south side of the pit there are yet remnants of the interglacial soil bed. The lower ten feet of the exposure is made up of coarse, cross-bedded sand which is sharply. defined from the still coarser gravel which constitutes the upper part of the deposit.

When the pit was seen by the writers in 1914 all but the upper part of the section was badly obscured. The upper part, however, was clean in part and showed the following:

Drift Two Mites West of Winthrop, Iowa.

3. Dark brown porous loamy clay containing a few pebbles .......................... $0-3$

2. Febble layer very definite, looks somewhat like till in places but very thin .................... $0-8$

1. Rusty brown stratified sand and gravel......... $3-6$

No trace was seen of the "interglacial soil" reported by Doctor Calvin above' No. 1.

Exposures beside the road one mile east of Independence (Township 88 North, Range 9 West, section 2, northwest quarter), where Doctor Calvin found two and one-half feet of Iowan drift overlying Buchanan gravel, were examined in 1914 and showed the following:

Drift ONe Mue EAst of INDEPENDENCE, Iowa.

2. Dark grayish to brownish sandy loam, slightly banded and inclosing scattered pebbles, small to six inches in diameter .............................. 1/2-2

1. Rusty brown gravel with a little sticky, brown clay intermingled. Pebbles small to eight inches or more in diameter, mostly less than one inch. Some granites thoroughly disintegrated .................... 3

A boring in the bottom of the excavation penetrated:

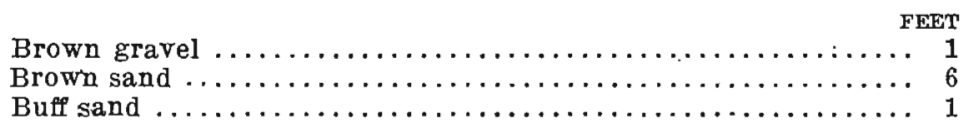

Limestone is exposed below a thin covering of drift in the road a short distance to the west and limestone was struck at a depth of ten feet in drilling a nearby well, so that it is probable that there is but little drift below the depth reached by the auger, that is, eleven or twelve feet from the original surface. Doctor Calvin regarded No. 1 as Buchanan gravel and No. 2 as 
Iowan drift. It is not very certain, however, that the latter is glacial till.

W J McGee ${ }^{i 1}$ reported buried soil and wood as having been encountered in digging wells three miles north of Independence in Washington township, (Township 89 North, Range 9 West, section 15, southwest quarter of the southeast quarter and in scction 22 , northeast quarter of the northeast quarter).

BLACK HAWK COUNTY.

Some exposures in Cedar Falls not far from the State Teachers College were examined. One of these is just north of the race track, in Township 89 North, Range 14 West, section 13, southeast quarter. This is at a pit in the big gravel deposit in the valley of a branch of Dry Run. The section is as follows:

Drift in Southeast Part of Cedar Falls, Iowa.

3. Clay, dark to brown, loamy, leached, containing some

FHET

pebbles. Till-like in part.................. 21/2-3

2. Sand and gravel, buff, stratified and cross-bidded,

leached . ......................... $4 y_{2}-5$

1. Sand and gravel, calcareous with plenty of limestone

pebbles $\ldots \ldots \ldots \ldots \ldots \ldots \ldots \ldots \ldots \ldots \ldots \ldots \ldots \ldots \ldots . \ldots \ldots$

While No. 3 is till-like in part the writers do not feel at all sure that it is glacial till. It might be the more poorly assorted part of the alluvial deposit laid down upon the gravels. The gravels also are fresh-looking, largely calcareous, and but little weathered, much less so than the typical Buchanan gravel. It is possible these gravels may be a part of the Wisconsin outwash swept down the Cedar valley and into the lower part of I)ry Run valley, though they may be older.

\section{BENTON COUNTY.}

A cut on the Waterloo, Cedar Falls \& Northern electric railway, one mile southeast of Urbana in Polk township (Township 86 North, Range 9 West, section 35 , southeast quarter), showed a lens (seven by sixteen feet in vertical section) of gravel above and sand below, included in solid buff to brown pebbly clay till. Fifty feet farther west six and one-half feet of similar brown gravel and sand was included in the till. The till is noncalcareous over the gravel but becomes calcareous downward between

\footnotetext{
iU. S. Geol. Survey Eleventh Ann. Rep., pp. 489, 519.
} 
the two deposits at a depth of eight or nine feet from the top. The relations shown in the cut suggest overriding of a deposit of sand and gravel by a readvance of the ice but afford no good evidence of a post-Kansan till deposit.

Only parts of the county along and near the Waterloo, Cedar Falls \& Northern railway, the Chicago, Milwaukee \& St. Paul railway, and the Chicago \& North Western railway were examined in 1914.

Professor T. E. Savage ${ }^{72}$ describes an exposure in the east bank of Mud creek in Taylor township, at the middle of the west line of section 27, which shows:

DRIET SOUTH OF VINTON, IOWA.

3. Fine-grained, yellow colored clay, containing no gravel... FEET $31 / 2$

2. Bed of yelow drift, containing pebbles and small granite

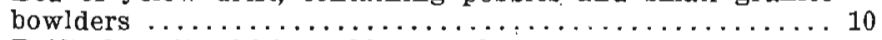

1. Drift deposit which is blue at the bottom, changes to a yellow color higher up, and at the very top is a deep red. This bed carries numerous pebbles and small bowlders of dark colored trap $\ldots \ldots \ldots \ldots \ldots \ldots \ldots \ldots \ldots \ldots \ldots$

Number 1 of the above section represents Kansan drift, the upper part of which presents the typical ferretto character. The contained greenstone pebbles and bowlders are characteristic of this ancient till. Number 2 is regarded as a deposit of Iowan drift. It is of a uniformly yellow color throughout. Its superficial portion is unleached of its calcareous matter, and its iron content is not more oxidized in one portion than anothér. The bed here is said to be much thicker than is usual for this till. Number 3 is a bed of loess.

\section{LINN COUNTY..}

A possible exposure of Iowan till was noted two miles west of Prairiesburg, in Boulder township (Township 86 North, Range. 5 West, section 20), near the west line of the bank of a tributary of Buffalo creek, where the following was seen:

Drdet Two Miles West of Prairiesburg, Iowa.

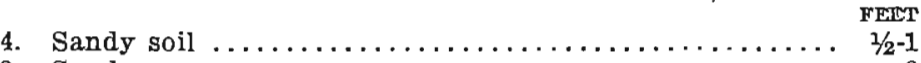

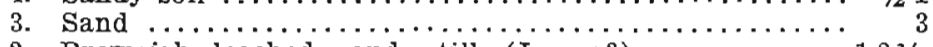

2. Brownish leached sandy till (Iowan?) ......... 1-2 1/2

1. Gray to brown interstratified sand and gravel, granite pebbles decayed, clay ironstones present but no limestone pebbles remain $\ldots \ldots \ldots \ldots \ldots \ldots \ldots \ldots \ldots \ldots \ldots, 5$

72Iowa Geological Survey, Vol. XV, p. 207, 1905. 
If the sand and gravel (No. 1) is Buchanan, No. 2 might be regarded as post-Kansan though the deposit is' so very thin and sandy that one could hardly be certain that it is glacial till.

JONES COUNTY.

Professor Calvin ${ }^{73}$ described an exposure in the railroad cut just west of Amber, as follows:

DRTF' WEST OF AMEer, IOWA.

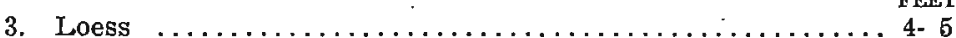

2. Till, yellow, with rather large pebbles and small bowlders (Iowan drift) ............................ 10

1. Blue clay with small pebbles, clay somewhat stratified

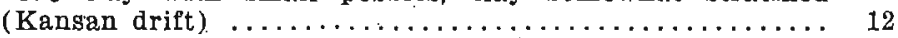

It seems not improbable that the yellow till is merely the oxidized portion of the Kansan since there is gradation from one to the other with no definite line of demarcation and no evidence of an interval of exposure between, such as is afforded by the soil and "gumbo" bed found in the exposures described on page 94 as present three miles to the northwest in section 30 , Wayne township.

ra Iowa Geological Survey, Vol. V, p. 65, 1895. 